\title{
Elemental systematics of the calcitic skeleton of Corallium rubrum and implications for the $\mathrm{Mg} / \mathrm{Ca}$ temperature proxy
}

Chaabane, S. ${ }^{1,2, *}$, López Correa, M. ${ }^{3,4}$, Ziveri, P. ${ }^{2,5}$, Trotter, J. ${ }^{6}$, Kallel, N. ${ }^{1}$, Douville, E. ${ }^{7}$, McCulloch, M. ${ }^{8}$, Taviani, M. ${ }^{4,9,10}$, Linares, C. ${ }^{11}$, Montagna, P. ${ }^{4,12}$

1) GEOGLOB, University of Sfax, 3038 Sfax, Tunisia

2) Institute of Environmental Science and Technology (ICTA), Universitat Autònoma de Barcelona (UAB), 08193 Bellaterra, Barcelona, Spain

3) GZN, GeoZentrum Nordbayern, Universität Erlangen-Nürnberg, Loewenichstr. 28, D91054 Erlangen, Germany

4) ISMAR-CNR, Istituto di Scienze Marine, Consiglio Nazionale delle Ricerche, Via Gobetti 101, 40129 Bologna, Italy

5) ICREA, Catalan Institution for Research and Advanced Studies, Pg. Lluís Companys 23, 08010 Barcelona, Spain

6) School of Earth Sciences and UWA Oceans Institute, University of Western Australia, Crawley, Australia

7) Laboratoire des Sciences du Climat et de l'Environnement, LSCE/IPSL, UMR 8212 CNRS-CEA-UVSQ, 91198, Gif-sur-Yvette, France

8) Oceans Graduate School, UWA Oceans Institute and ARC Centre of Excellence for Coral Reef Studies, University of Western Australia, Crawley, Australia

9) Biology Department, Woods Hole Oceanographic Institute, 266 Woods Hole Road, MA 02543, USA

10) Stazione Zoologica Anton Dohrn, Villa Comunale, 80121 Naples, Italy

11) Department of Evolutionary Biology, Ecology and Environmental Sciences, Institut de Recerca de la Biodiversitat (IRBIO), University of Barcelona, Av. Diagonal 643, 08028 Barcelona, Spain

12) Lamont-Doherty Earth Observatory, Columbia University, 61 Route 9W, Palisades, NY 10964, USA

* Corresponding author: Sonia Chaabane (sonia.chaabane@gmail.com)

\section{Abstract}

The high-Mg calcite skeleton of Corallium rubrum was analyzed from living colonies collected from a wide range of depths $(15 \mathrm{~m}$ to $607 \mathrm{~m})$ and environmental settings in the Mediterranean Sea. An overarching goal was to better understand the calcification process and incorporation of elements into the slow-growing skeleton of both shallow and deep-water specimens, and more specifically, to clarify the veracity of geochemical proxies for reconstructing seawater temperatures. The coral internal structure including growth bands were determined by scanning electronic microscopy (SEM) and petrographic techniques. Trace elements ( $\mathrm{Li}, \mathrm{B}, \mathrm{Mg}, \mathrm{Sr}$ and $\mathrm{Ba}$ ) compositions of the coral skeleton were obtained by 
solution and laser ablation inductively coupled plasma mass spectrometry (ICP-MS). Results show that the skeleton of the deep-water specimens has an internal microstructure similar to shallow-water colonies, with the medullar and the annular zones clearly distinguishable in both shallow and deep-water specimens. In general, the bands of the deep-water samples are very thin and equidistant compared to the irregular banding of the shallow-water specimens. Banding differences relate to the contrasting environmental dynamics, with the shallow-water specimens being exposed to large seasonal fluctuations compared to the relative stable conditions of those inhabiting bathyal depths. The inner medullar and outer annular portions differ in their trace element concentrations: $\mathrm{Mg} / \mathrm{Ca}, \mathrm{Sr} / \mathrm{Ca}$ and $\mathrm{Li} / \mathrm{Ca}$ ratios are higher in the medullar zone and seem to be influenced by growth kinetics, whereas $\mathrm{B} / \mathrm{Ca}$ and $\mathrm{Ba} / \mathrm{Ca}$ are similar in both zones and hence unaffected by growth rate. The variability of elemental ratios is lower in the deep-water specimens. Growth bands are highly correlated to $\mathrm{Mg} / \mathrm{Ca}, \mathrm{Sr} / \mathrm{Ca}$ and $\mathrm{Li} / \mathrm{Ca}$, suggesting common mechanism(s) controlling the incorporation of these elements into the coral skeleton. $\mathrm{Mg} / \mathrm{Ca}$ ratios were especially depleted in the dark bands. Although the mean $\mathrm{Mg} / \mathrm{Ca}$ of each specimen is positively correlated to ambient seawater temperature, the intra-annual variations and amplitudes differ and do not correlate to the band widths. These findings suggest that intra- and inter-annual variations of $\mathrm{Mg} / \mathrm{Ca}$ cannot be used to reconstruct a continuous time-series of long-term seasonal temperature records. However, the mean $\mathrm{Mg} / \mathrm{Ca}$ composition can serve as a valuable proxy to estimate mean palaeoseawater temperature at a given site within the Mediterranean.

\section{Keywords}

Red coral, Corallium rubrum, Mediterranean Sea, Calcite skeleton, Growth bands, Trace elements, Temperature proxy.

\section{Introduction}

The Mediterranean Sea is recognized as one of the fastest warming regions (Bindoff et al., 2007; Burrows et al., 2011) affected by climate change (Giorgi, 2006). This is due to its geographic position between the mid-latitude westerlies of central and northern Europe, the subtropical high-pressure belt over North Africa, and its semi-enclosed nature. Local, regional, and basin scale hydrological properties of the Mediterranean Sea are mainly linked to the North Atlantic Oscillation (NAO) and the Northern Hemisphere temperature indexes, 
suggesting that the Mediterranean climatic shifts are modulated by large scale changes in the Northern Hemisphere (Conversi et al., 2010). Recent studies documented a rapid sea surface warming throughout the basin, with the Mediterranean warming trend being several times larger than the global ocean average over the last two decades (e.g. Diffenbaugh et al., 2007; Vargas-Yáñez et al., 2008; Raitsos et al., 2010; Skliris et al., 2012).

Understanding whether these seawater temperature changes are driven by human activity or are within the natural climate variability range, requires long-term (multi-decadal, centennial) continuous records, extending beyond observational and instrumental records. Proxy-based paleoclimate reconstructions can help overcome these data limitations; in particular, the geochemical composition of shallow- and deep-water aragonite and calcite corals has been widely used to reconstruct seawater conditions, such as sea surface temperature (SST), salinity, and pH (Beck et al., 1992; Mitsuguchi et al., 1996; Gagan et al., 2000; Pelejero et al., 2005; Corrège, 2006; Thresher et al., 2009; Douville et al., 2010; Sinclair et al., 2011; Hill et al., 2012; McCulloch et al., 2012; Shinjo et al., 2013; Montagna et al., 2014; Kimball et al., 2016).

Coral-based paleoclimatic studies in the temperate Mediterranean Sea have thus far been focused on deep-water scleractinians (Montagna et al., 2005; Montagna et al., 2006; López Correa et al., 2010; McCulloch et al., 2010; McCulloch et al., 2012; Fink et al., 2013; Fink et al., 2015; Dubois-Dauphin et al., 2017; Montagna and Taviani, 2019), and to a lesser degree on shallow water species (Peirano et al., 2004; Silenzi et al., 2005; Montagna et al., 2007; Montagna et al., 2008; Trotter et al., 2011; Tisnérat-Laborde et al., 2013).

Here, we focus on the scleraxonian octocoral Corallium rubrum, which is endemic to the Mediterranean. C. rubrum (Linnaeus, 1758) has been commercially exploited since antiquity because of its attractive red axial calcitic skeleton (Tescione, 1973; Taviani, 1997; Morel, 2000; Tsounis et al., 2007) that has distinct annual banding (Lacaze-Duthiers, 1864). The coral inhabits a wide range of environments, from shallow warm waters $(\sim 5 \mathrm{~m})$ with large interannual temperature amplitudes, to deeper and colder bathyal conditions ( $1016 \mathrm{~m})$ with almost no interannual variability (Rossi et al., 2008; Freiwald et al., 2009; Costantini et al., 2010; Linares et al., 2010; Taviani et al., 2010; Abbiati et al., 2015; Cau et al., 2015; Knittweis et al., 2016; Rueda et al., 2019). Its calcification rate and annual increment width are influenced by interannual temperature variability and thus provide a useful tool for paleoclimatic studies (Vielzeuf et al., 2008; Vielzeuf et al., 2013; Galli et al., 2016), which has also been suggested by geochemical paleoclimate reconstructions (Velimirov and Böhm, 
1976; Weinbauer and Velimirov, 1995; Weinbauer et al., 2000; Yoshimura et al., 2011; Vielzeuf et al., 2013). Detrimental effects of ocean acidification on C. rubrum have also been reported (Bramanti et al, 2013; Cerrano et al, 2013). Fossil C. rubrum of Miocene to Holocene age have also been used for paleoceanographic reconstructions (Barrier et al., 1991; Di Geronimo et al., 1993, Vertino et al., 2010; Vertino et al., 2014; Lodolo et al., 2017).

Prior studies have investigated the internal microstructures (Vielzeuf et al., 2008; Vielzeuf et al., 2010; Floquet and Vielzeuf, 2011; Floquet and Vielzeuf, 2012 ; Le Goff et al., 2017; Perrin et al., 2017) and geochemical compositions of the calcitic skeleton of shallow-water specimens of C. rubrum (Weinbauer et al., 2000; Dauphin, 2006; Vielzeuf et al., 2008; Floquet and Vielzeuf, 2011; Floquet and Vielzeuf, 2012; Hasegawa et al., 2012; Vielzeuf et al., 2013; Perrin et al., 2015; Chaabane et al., 2016; Vielzeuf et al., 2018). The incorporation of $\mathrm{Mg} / \mathrm{Ca}$ ratios of the sclerites and axial skeleton have shown to be temperature dependent (Weinbauer and Velimirov, 1995; Velimirov and Böhm 1976; Weinbauer et al., 2000) and that $\mathrm{Sr} / \mathrm{Ca}$ is a potential proxy of growth rate (Weinbauer et al., 2000). Conversely, recent work (Vielzeuf et al., 2013) concluded that $\mathrm{Mg} / \mathrm{Ca}$ in $C$. rubrum is an indicator of growth rate and anomalous stress events. Stable isotope sampling of C. rubrum by Chaabane et al. (2016) showed that both $\delta^{18} \mathrm{O}$ and $\delta^{13} \mathrm{C}$ are strongly influenced by kinetic vital effects, which impede the direct extraction of temperature time-series reconstructions at inter- and intra-annual scales.

In the present study, we used laser ablation inductively coupled plasma mass spectrometry (LA-ICP-MS) to measure the elemental composition of C. rubrum skeletons at intra-annual resolution, which was compared to monthly resolution temperature data from $\sim 10$ years of in situ logger measurements. We explore the feasibility of reconstructing temperature records from skeletal $\mathrm{Mg} / \mathrm{Ca}$ together with biological controls (e.g. band-width and vital effects) on the geochemical signal.

\section{Materials and methods}

\subsection{Sample collection}

Five living colonies of C. rubrum were collected from the Mediterranean Sea at different depths (Fig. 1 and Tab. 1): four colonies were retrieved using SCUBA in June-July 2008 at Riou Island (RI), Medes Islands (MI) and Corsica (CO) from depths of 15, 18 and $21 \mathrm{~m}$ respectively, and in May 2009 off Portofino (PF) at $50 \mathrm{~m}$ depth. One colony (MS-43) was 
hauled from 607 m offshore SW Malta in December 2007 during the MARCOS cruise with Italy’s R/V Urania. Samples RI, MI, CO and PF were previously analyzed for $\delta^{18} \mathrm{O}$ and $\delta^{13} \mathrm{C}$ and those results are reported in Chaabane et al. (2016).

\subsection{Environmental settings}

Seawater temperature data were sourced from two different databases: hourly temperature data obtained from the T-MedNet project using StowAway TidbiT data loggers (www.tmednet.org) at 15-20 m close to the coral sites, were used to calculate both the means and ranges in annual temperatures for the sample locations of Medes Islands, Corsica, and Riou Island (Tabs. 1 and S1, Fig. 1). Logger data cover the years 2004 to 2014 at Medes Islands and Corsica (at $20 \mathrm{~m}$ depth for both stations) and 2003 to 2015 at Riou Island (at $15 \mathrm{~m} \mathrm{depth}$ ). The temperature values representing the conditions at the coral sites in Portofino and SW Malta were sourced from the NOAA NODC WOA13 $\left(0.25^{\circ}\right.$ grid) database (Boyer et al., 2013). Monthly means were calculated from hourly T-MedNet data recorded by the loggers. The 12-monthly means were averaged to determine annual temperatures, whereas the annual ranges were calculated as the difference between the warmest and coldest month. Similarly, the annual means and annual range for the samples PF and MS-43 were calculated from the monthly NOAA NODC WOA13 data (Tab. 1 and Fig. 1).

Annual mean temperatures range from $13.81 \pm 0.07^{\circ} \mathrm{C}$ at the bathyal site (MS-43), to $17.34 \pm 3.26^{\circ} \mathrm{C}$ in the shallow waters $(\mathrm{CO})$, with these two sites having the lowest $\left(0.24^{\circ} \mathrm{C}\right)$ and highest $\left(8.52^{\circ} \mathrm{C}\right)$ annual amplitudes respectively (Tab. 1 and Fig. 1A). Seawater temperature values sourced from the NOAA NODC WOA13 database were found to be very similar to those reported in the literature. Della Croce et al. (1979) reported a seawater mean temperature of $14.8^{\circ} \mathrm{C}$ at $50 \mathrm{~m}$ water depth off Portofino, which is comparable to WOA13 $\left(14.61^{\circ} \mathrm{C}\right)($ Tab. 1). Furthermore, the temperature data recorded between January 2007 and December 2016 at $50 \mathrm{~m}$ at station Point B in the Bay of Villefranche (France), about 90 nautical miles from Portofino, gave a mean temperature value of $15.48 \pm 1.58{ }^{\circ} \mathrm{C}$, with the temperature varying from 13.62 to $18.79^{\circ} \mathrm{C}$ (Gattuso et al. 2017). Deep-water temperatures close to the MS-43 coral site in the Siculo-Tunisian Strait vary slightly from 13.83, 13.89 and $14.05^{\circ} \mathrm{C}$, which were recorded at depths between 542 and $600 \mathrm{~m}$ in April 1974 (at

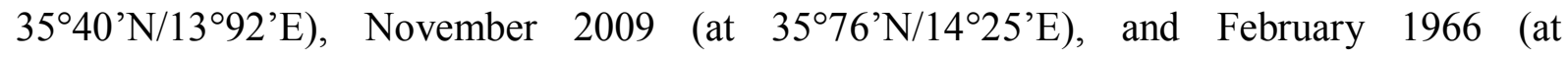

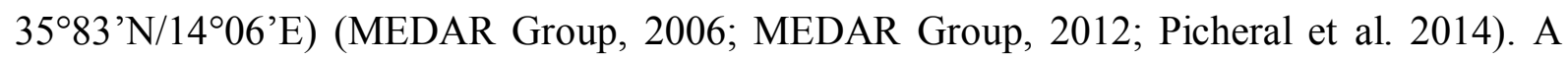


temperature value of $13.78^{\circ} \mathrm{C}$ was measured by CTD in April 2007 at 460 m, nearby the coral site sampled during the MARCOS cruise.

Annual mean salinity values retrieved from the NOAA NODC WOA13 (0.25 grid) database, range from $37.75 \pm 0.06$ to $38.02 \pm 0.01$ for the shallow water sites and $38.76 \pm 0.02$ for the bathyal site of MS-43.

\subsection{Skeletal architecture and growth bands}

The skeletal architecture and internal bands comprising C. rubrum were examined to compare the growth pattern of deep and shallow-water specimens and to explore potential temperature effects on banding organization. Annual increments were counted to assess the corals' ages which provided chronological constraints on the laser-ablation geochemical records extracted from each stem.

\subsubsection{Thin section preparation}

A 5-7 mm thick disk was cut at the base of the colony of each coral specimen using a diamond blade. Cross-sections were embedded in epoxy resin (Araldit and Araldur) and cured at room temperature for $24 \mathrm{~h}$. Epoxy blocks were trimmed with a Buehler ISOMET low-speed saw, then polished with silica-carbide powder (800 grit), glued to glass slides, lapped to a final thickness between 70 and $35 \mu \mathrm{m}$, and cleaned in an ultrasonic bath.

\subsubsection{Petrographic Microscopy}

Coral transverse sections were examined under a stereomicroscope (ZEISS) in transmitted and polarized light to determine skeleton macrostructure and growth bands patterns in the basal stem sections. The dark and light growth rings were counted along several transects across the basal stem. The thin sections were also scanned with a Nikon Coolscan slidescanner to enhance the imaging of growth rings.

\subsubsection{Scanning Electron Microscopy}

Scanning Electron Microscopy (SEM) in backscattered (BSE) and secondary electron (SE) modes (Zeiss Evo MA 10 at UAB and VEGA XMU Tescan at GZN) was used to explore the 
microstructures of broken branches and growth band patterns of the different specimens. Samples were either gold or carbon sputter-coated then analysed under vacuum in the SEM. Accelerating voltage and probe current ranged between 15 and $20 \mathrm{kV}$ and between 0.1 and 2 $\mathrm{nA}$, respectively. The working distance varied from 5.5 to $10 \mathrm{~mm}$ for the SE mode and from 5 to $16.63 \mathrm{~mm}$ for the BSE mode.

\subsubsection{Organic matrix staining}

Following the organic matrix staining (OMS) method of Marschal et al. (2004), the thin sections were decalcified in $2 \%$ acetic acid solution for 4 to $5 \mathrm{~h}$, then gently rinsed in tap water, stained with Toluidine Blue $0.05 \%$ aqueous solution for $10-30 \mathrm{~s}$, and dried in air. The thin section of the deep-water coral was etched twice with acetic acid to improve the etching of the organic matrix.

\subsubsection{Growth band counts and measurements}

The age and thickness of the growth bands comprising samples MI, RI, PF and MS-43 were estimated using the OMS method, by counting the dark and light bands through a stereomicroscope, noting that each dark-light pair represents 1 year of growth (Marschal et al., 2004). The annual growth bands in C. rubrum comprise pairs of light and dark bands, which develop from spring to fall and then from late fall to winter respectively (Marschal et al., 2004). The OMS band counts determined in the present study were compared to their respective petrographic and SEM data. For each specimen, the counting was conducted along several transects in the annular zone (Fig. 2) within different portions of the colony, avoiding parts that showed growth perturbations (e.g. former polyps) or hiatuses (apparent missing bands). The thickness of the growth rings was measured using the publicly accessible imageprocessing program Image J (Schneider et al., 2012). The OMS data were also used to correlate the growth band thicknesses to the geochemical profiles.

\subsection{Geochemical composition}

\subsubsection{Laser ablation ICP-MS}

$\mathrm{Li} / \mathrm{Ca}, \mathrm{B} / \mathrm{Ca}, \mathrm{Mg} / \mathrm{Ca}, \mathrm{Sr} / \mathrm{Ca}$ and $\mathrm{Ba} / \mathrm{Ca}$ ratios were measured by laser ablation inductively coupled plasma mass spectrometry (LA-ICP-MS) along two parallel tracks across the axial 
skeleton of specimens RI, CO, MI and MS-43 (Fig. 3). The measurements were performed in 2008 at the Research School of Earth Sciences in Canberra (Australia) using an $193 \mathrm{~nm}$ ArF excimer laser system (Lambda Physik LPX 120i) connected to a quadrupole ICP-MS (Varian 820-MS). Discs sampled from of the coral skeletons were first cleaned with MilliQ water in an ultrasonic bath, dried overnight at $40^{\circ} \mathrm{C}$, embedded in epoxy resin, then trimmed with a diamond saw. The laser was operated at $10 \mathrm{~Hz}$ and $50 \mathrm{~mJ}$ and the laser beam was masked using a $10 \mu \mathrm{m}$ wide and $400 \mu \mathrm{m}$ long rectangular slit, with its long side parallel to the growth rings. The coral samples were scanned continuously at $20 \mu \mathrm{m} / \mathrm{s}$. Each sample was bracketed by the background (gas blank), NIST glass standards 612 and 614, and an in-house pressed aragonite coral standard measured for $60 \mathrm{~s}$, following previously described methods (Sinclair et al., 1998; Montagna et al., 2007; Montagna et al. 2014). The isotopes monitored were ${ }^{7} \mathrm{Li}$, ${ }^{11} \mathrm{~B},{ }^{25} \mathrm{Mg},{ }^{84} \mathrm{Sr}$ and ${ }^{138} \mathrm{Ba}$ normalized to ${ }^{43} \mathrm{Ca}$. The multiple analyses of the NIST and coral standard during the analytical session were used to assess the external reproducibility ( $1 \sigma$ RSD): $4.5 \%$ for $\mathrm{Li} / \mathrm{Ca}, 3.8 \%$ for $\mathrm{B} / \mathrm{Ca}, 5.7 \%$ for $\mathrm{Mg} / \mathrm{Ca}, 1.6 \%$ for $\mathrm{Sr} / \mathrm{Ca}$ and $4.2 \%$ for $\mathrm{Ba} / \mathrm{Ca}$.

\subsubsection{Solution quadrupole ICP-MS}

A portion of the outermost surface of samples RI, CO, MI, PF and MS-43, that encompassed the last 2-3 years of growth, was micro-milled using a dental drill with diamond-encrusted burrs. The coral powders were dissolved in ultraclean nitric acid to obtain solutions of 100 ppm $\mathrm{Ca}$ in $0.5 \mathrm{~N} \mathrm{HNO}_{3}$ matrix. $\mathrm{Li} / \mathrm{Ca}, \mathrm{B} / \mathrm{Ca}, \mathrm{Mg} / \mathrm{Ca}, \mathrm{Sr} / \mathrm{Ca}$ and $\mathrm{Ba} / \mathrm{Ca}$ were measured using a quadrupole ICP-MS X-series ${ }^{\text {II }}$ at the LSCE (Gif-sur-Yvette, France) following the protocol described in Montagna et al. (2014), but recently revised to obtain a higher analytical precision (Curry-Guirriec et al., 2019). The external reproducibility ( $1 \sigma \mathrm{RSD}, \mathrm{n}=21)$ obtained by the analysis of the reference coral JCp-1 (Hathorne et al., 2013) was $0.7 \%$ for $\mathrm{Li} / \mathrm{Ca}, 1.0 \%$ for $\mathrm{B} / \mathrm{Ca}, 0.5 \%$ for $\mathrm{Mg} / \mathrm{Ca}, 0.3 \%$ for $\mathrm{Sr} / \mathrm{Ca}$ and $3.5 \%$ for $\mathrm{Ba} / \mathrm{Ca}$. The mean molar ratios obtained for JCp-1 were $6.24 \pm 0.04 \mu \mathrm{mol} / \mathrm{mol}, 459 \pm 5 \mu \mathrm{mol} / \mathrm{mol}, 4.20 \pm 0.02 \mu \mathrm{mmol} / \mathrm{mol}$, $8.86 \pm 0.03 \mathrm{mmol} / \mathrm{mol}$ and $7.35 \pm 0.26 \mu \mathrm{mol} / \mathrm{mol}$, respectively. The results of the $\mathrm{Mg} / \mathrm{Ca}$ ratio were used to correct the laser ablation ICP-MS values.

\subsubsection{Statistical analysis}

Statistical analyses were performed to investigate the relationships between different element/Ca ratios in both medullar and annular zones of C. rubrum, as well as in situ seawater 
temperature and $\mathrm{Mg} / \mathrm{Ca}$ ratios. The Pearson product-moment correlation coefficient ( $\mathrm{r}$ ) and the coefficient of determination $\left(\mathrm{r}^{2}\right)$ of the linear regression were calculated through the IBM SPSS Statistics (Version 20) software package.

\section{Results}

\subsection{Skeletal architecture}

Macroscopically, the deep-water coral MS-43 presents a light red skeleton, whereas shallowwater specimens are dark red. SEM examination of the internal micro-structures across a broken branch of the axial skeleton of samples MI and MS-43, shows similar microstructural units in both shallow and deep-water specimens, which comprise microprotuberances on the surface, fibrous to bladed calcite, and crystalline units of submicron size (Figs. 4A-H). The surface of the axial skeleton of the deep-water specimen MS-43 is covered entirely by 20-30 $\mu \mathrm{m}$ high microprotuberances, regularly spaced every 15 to $40 \mu \mathrm{m}$, between which are granular structures of a few $\mu \mathrm{m}$ (Fig. 4B). The internal architecture comprises fibrous calcite that are hexagonal in cross-section $(\sim 10 \mu \mathrm{m}$ wide; Fig. $4 \mathrm{C})$ and stacked calcite blades (Fig. 4D). Submicron crystals are isometricand a few tens to few hundreds of nanometers in size (Fig. 4A). The microstructure of the shallow-water coral MI comprises sclerites that are densely distributed on the surface, which range in size from either 20 to $40 \mu \mathrm{m}$ (Fig. 4F) or submicron to several microns in size (Fig. 4E). Fibres and blades in MI are 20 to $30 \mu \mathrm{m}$ in size (Figs. 4G, H).

\subsection{Growth bands}

The thin sections of the shallow-water specimens show distinct, concentric, light and dark bands within the annular zone (Fig. 2). The clarity and number of growth band observed varies depending on the technique used (i.e. stereomicroscope, SEM or OMS staining). Overall, the OMS approach provides the highest resolution by clearly showing most of the fine features of the growth rings (Figs. 2C, F, I, L) enabling precise counting of the bands (Tab. 2). The SEM images obtained in backscattered mode from untreated thin sections show clear light-dark banding for sample MI (Fig. 2B) only, whereas no banding is visible in the deep-water coral MS-43 (Fig. 2H). The ability to resolve bands is also partly dependent on the image resolution and magnification, with petrographic analysis being the least effective method for distinguishing growth bands (Figs. 2A, D, G J). 
OMS analyses show that most samples have an asymmetric pattern of bands with varying widths (Figs. 5A, B). However, the number of growth bands along different transects within the annular zone, avoiding growth perturbations (hiatus, polyps), is generally very similar when using the OMS approach, leading to a better chronology compared to the petrographic method and SEM. Nevertheless, counting bands along multiple transects will minimize errors in assessing coral ages and provide the most reliable chronologies.

Estimates of the longevity of the sample analysed using the three different techniques are given in Table 2. The ages estimated using the OMS approach are higher compared to those obtained using petrography and SEM. This is particularly evident for sample MS-43 for which $70 \pm 4$ growth rings were determined using OMS, and $12 \pm 2$ from petrographic examination. The OMS data show that the deep-water coral, MS-43, is the oldest sample (i.e. $\sim 70$ years old $)$ in this study and had the slowest mean growth rate $(95 \pm 75 \mu \mathrm{m} / \mathrm{yr})$ compared to the shallow-water colonies that grew at rates between $172 \pm 7$ and $276 \pm 65 \mu \mathrm{m} / \mathrm{yr}$ (Tab. 2).

Sample MS-43 shows three distinct skeletal regions, comprising a central medullar area where growth rings are not developed, an annually banded zone that reveals a very thin banding pattern and an additional area between these zones displaying intermediate characteristics. At places, the growth bands are interrupted (Fig 5B).

Figure 5 and Table S2 highlight differences in thickness between the dark and the light bands when applying the OMS approach on shallow (RI, MI and PF) and deep-water (MS-43) corals. In the latter, the thickness of the annual growth rings (i.e. light and dark pairs) is relatively constant (mean value of $45 \pm 11 \mu \mathrm{m}$ ) and ranges between 68 and $22 \mu \mathrm{m}$. Conversely, band thickness in the shallow-water corals varies considerably, from $\sim 30 \mu \mathrm{m}$ to $\sim 310 \mu \mathrm{m}$. The coral PF shows the thickest growth bands, with a mean value of $93 \pm 53 \mu \mathrm{m}$, and samples RI and MI present similar mean thicknesses of $78 \pm 25$ and $68 \pm 39 \mu \mathrm{m}$ respectively. Based on the OMS method, the average thickness of the dark bands in samples RI, MI, PF and MS-43 is $32 \pm 9,14 \pm 11,26 \pm 9$ and $15 \pm 5 \mu \mathrm{m}$, respectively (Tab. S2 and Fig. 5). The dark bands are thinner than the light bands both for the shallow- and deep-water specimens. They represent $\sim$ 43, 21, 32 and 33\% of the entire annual band for the RI, MI, PF and MS-43 specimens, respectively (Fig. 5C, D, E, F, Tab. S2).

The mean thickness of the growth bands for all of the samples are plotted against the annual mean in situ temperatures (Fig. 5G). The light and dark band thicknesses show a slight positive correlation with summer and winter temperatures (Fig. $5 \mathrm{H}$ ). 


\subsection{Element/Ca variations}

The element/Ca ratios obtained by laser ablation ICP-MS along two parallel tracks across the entire basal cross section of the specimens RI, CO, MI and MS-43 are shown in Figure 6 and Table S3. One of the two transects in each sample crosses both the annular and medullar zone along the mid-part of the transverse section, whereas the other track is slightly offset, comprising mostly the annular growth (Fig. 3). Given the irregular and asymmetric growth patterns of our specimens, the laser track was not always perpendicular to the growth increments.

Apparent $\mathrm{Mg} / \mathrm{Ca}$ fractionation of the laser data was corrected using the solution-ICP-MS analyses, as the former yielded significantly lower $\mathrm{Mg} / \mathrm{Ca}$ ratios than those reported in previous studies of C. rubrum (Vielzeuf et al. 2013). The observed shift between laser and solution-based $\mathrm{Mg} / \mathrm{Ca}$ ratios might be due to an elemental fractionation specific to laser analyses, and/or the matrix of the standards used to calibrate the data, which differ in $\mathrm{Mg} / \mathrm{Ca}$ compositions compared to the skeletal calcite. The pressed aragonite coral standard has a $\mathrm{Mg} / \mathrm{Ca}$ bulk composition that is much lower than the calcite skeleton of C. rubrum $(\sim 4.2$ $\mathrm{mmol} / \mathrm{mol}$ vs. $120 \mathrm{mmol} / \mathrm{mol}$ ), which could produce a chemical matrix bias. This is not the case for the other element/Ca ratios that show comparable values between coral standard and the calcite skeleton.

The laser ablation $\mathrm{Mg} / \mathrm{Ca}$ ratios were corrected by applying a constant offset for each specimen (i.e. the difference between the solution-based ICP-MS value of the external surface and the laser results for the same portion). The mean difference between laser ablation and solution-based ICP-MS is $3.09 \pm 2.33 \mu \mathrm{mol} / \mathrm{mol}$ for $\mathrm{Li} / \mathrm{Ca}, 0.03 \pm 0.02 \mathrm{mmol} / \mathrm{mol}$ for $\mathrm{B} / \mathrm{Ca}$, $11.24 \pm 1.09 \mathrm{mmol} / \mathrm{mol}$ for $\mathrm{Mg} / \mathrm{Ca}, 0.05 \pm 0.04 \mathrm{mmol} / \mathrm{mol}$ for $\mathrm{Sr} / \mathrm{Ca}$ and $0.51 \pm 0.33 \mu \mathrm{mol} / \mathrm{mol}$ for $\mathrm{Ba} / \mathrm{Ca}$ (Tab. 3).

Both transects reveal high-frequency micro-scale element/Ca oscillations, with most of the elements showing higher values in the central portion (medullar) compared to the external part of the skeleton (annular), especially for $\mathrm{Li} / \mathrm{Ca}, \mathrm{Mg} / \mathrm{Ca}$ and $\mathrm{Sr} / \mathrm{Ca}$ (Fig. 6, Tab. 3). Conversely, $\mathrm{Ba} / \mathrm{Ca}$ ratios are indistinguishable (within analytical error) between medullar and annular zones (Tab. 3). Overall, the fine-scale element/Ca variations are smaller in the deepwater specimen MS-43 than the shallow-water samples. 
The mean $\mathrm{Mg} / \mathrm{Ca}$ value for each specimen varies from $130.39 \pm 9.72 \mathrm{mmol} / \mathrm{mol}$ in Medes Islands to $115.70 \pm 6.12 \mathrm{mmol} / \mathrm{mol}$ offshore SW Malta, which corresponds to $\sim 13 \%$ difference between the shallow- and deep-water samples. The mean $\mathrm{Li} / \mathrm{Ca}, \mathrm{B} / \mathrm{Ca}$ and $\mathrm{Ba} / \mathrm{Ca}$ values also vary among samples (Tab. 3), with maximum differences up to $38 \%, 30 \%$ and $24 \%$, respectively. The highest mean $\mathrm{Ba} / \mathrm{Ca}$ value is observed in the deep-water coral MS-43. The mean $\mathrm{Sr} / \mathrm{Ca}$ values that are however quite similar between samples, their differences being $<10 \%$.

The percentage of variation for $\mathrm{Li} / \mathrm{Ca}, \mathrm{B} / \mathrm{Ca}, \mathrm{Mg} / \mathrm{Ca}, \mathrm{Sr} / \mathrm{Ca}$ and $\mathrm{Ba} / \mathrm{Ca}$ along the entire coral cross sections, in the annular and medullar zones are given in Table 3. The $\mathrm{Li} / \mathrm{Ca}$ and $\mathrm{B} / \mathrm{Ca}$ ratios have higher spatial variability compared to $\mathrm{Mg} / \mathrm{Ca}, \mathrm{Sr} / \mathrm{Ca}$ and $\mathrm{Ba} / \mathrm{Ca}$ ratios. Overall, the deep-water specimen (MS-43) exhibits less element/Ca variability along the entire transect in the annular and medullar zones compared to samples MI, RI, and CO. Among the shallowwater corals, the sample from Medes Islands (MI) shows the least variability.

\subsection{Correlation between element/Ca ratios}

The relationships between the different element/Ca ratios for the different structural zones (i.e. annular vs. medullar) were investigated using the Pearson product-moment correlation coefficient ( $r$ ) (Tabs. 4, 5 and 6). Overall, correlations between element/Ca ratios for the shallow-water specimens RI, $\mathrm{CO}$, and $\mathrm{MI}$, range from -0.50 to 0.88 (Tabs. 4 and 6). $\mathrm{Mg} / \mathrm{Ca}$ ratio has a positive correlation with $\mathrm{Sr} / \mathrm{Ca}(\mathrm{r}=0.56$ for $\mathrm{RI}, 0.38$ for $\mathrm{CO}$ and 0.76 for $\mathrm{MI}$ ), $\mathrm{Li} / \mathrm{Ca}(\mathrm{r}=0.40$ for RI, 0.31 for $\mathrm{CO}$ and 0.59 for $\mathrm{MI})$, and $\mathrm{B} / \mathrm{Ca}(\mathrm{r}=0.55$ for $\mathrm{RI}, 0.27$ for $\mathrm{CO}$ and 0.36 for MI). Similarly, $\mathrm{Sr} / \mathrm{Ca}$ shows a positive correlation with $\mathrm{Li} / \mathrm{Ca}, \mathrm{B} / \mathrm{Ca}$, and $\mathrm{Ba} / \mathrm{Ca}$ (Tabs. 4 and 6). $\mathrm{Li} / \mathrm{Ca}$ is weakly correlated with most of the ratios including $\mathrm{B} / \mathrm{Ca}$ ( $\mathrm{r}$ between 0.17 and 0.46 ) and $\mathrm{Ba} / \mathrm{Ca}$ (r between 0.02 and 0.41 ). For some ratios (e.g. $\mathrm{Mg} / \mathrm{Ca}$ and $\mathrm{Sr} / \mathrm{Ca}$ ), the correlation is higher in the annually banded zone compared to the medullar zone.

The deep-water coral MS-43, shows similar elemental correlations as observed in the shallowwater colonies, with $r$ values of the full data set ranging from -0.39 to 0.89 (Tab. 5). Generally, the correlations between the element/Ca obtained for MS-43 are slightly lower than the shallow-water data, with $\mathrm{Li} / \mathrm{Ca}$ vs. $\mathrm{Mg} / \mathrm{Ca}$ yielding the highest correlation $(\mathrm{r}=0.89$ in the medullar zone). 


\subsection{Element/Ca vs. skeletal microstructures}

Figure 7 shows the LA-ICP-MS element/Ca profiles for transect \#6 of the sample from Medes Islands plotted against the image of the thin section stained with Toluidine blue, with the position (and hence thickness) of the dark thin bands also shown (pink lines). The two sides of the annually banded annular zone show similar element/Ca trends but different small-scale variations for most of the elements. However, within both sides, there is a relationship between some of the element/Ca ratios and the growth bands. The light bands are mostly associated with high $\mathrm{Mg} / \mathrm{Ca}$ and $\mathrm{Sr} / \mathrm{Ca}$ values, and to a lesser extent with high $\mathrm{Li} / \mathrm{Ca}$ ratios (Fig. 7), whereas there is no clear and systematic link between $\mathrm{B} / \mathrm{Ca}$ and $\mathrm{Ba} / \mathrm{Ca}$ and the annual growth rings in the annular zone. The medullar zone is enriched in $\mathrm{Mg} / \mathrm{Ca}(\sim+20 \%)$ and $\mathrm{Sr} / \mathrm{Ca}(\sim+10 \%)$, and depleted in $\mathrm{Ba} / \mathrm{Ca}(\sim-10 \%)$ compared to the annular zone.

Comparison of the thicknesses of growth layers and the corresponding element/Ca values reveals a significant positive correlation for $\mathrm{Mg} / \mathrm{Ca}$ ratio $(\mathrm{r}=0.45)(\mathrm{Tab} .6)$. Although $\mathrm{Li} / \mathrm{Ca}$ and $\mathrm{Sr} / \mathrm{Ca}$ ratios are highly correlated with $\mathrm{Mg} / \mathrm{Ca}(\mathrm{r}=0.598$ and 0.769 , respectively), they show are weakly correlated with growth rate $(r=0.223$ and 0.354 , respectively). Very weak correlations are observed between the thicknesses of the light and dark bands and the $\mathrm{B} / \mathrm{Ca}(\mathrm{r}$ $=0.234)$ and $\mathrm{Ba} / \mathrm{Ca}(0.231)$ ratios.

\subsection{C. rubrum $\mathrm{Mg} / \mathrm{Ca}$ ratio vs. temperature}

This study primarily aimed to explore the relationships between seawater temperature and the $\mathrm{Mg} / \mathrm{Ca}$ skeletal compositions and growth band thicknesses in C. rubrum. Seawater temperature is considered as the main parameter controlling C. rubrum growth rate (Galli et al., 2016; Vielzeuf et al., 2019), with the thickest Mg-enriched (light) bands developing during warmer conditions (spring to fall), and the thinnest Mg-depleted (dark) bands forming during colder temperatures (late fall and winter) (Marschal et al., 2004; Vielzeuf et al., 2008). Figure 8 shows the fine-scale $\mathrm{Mg} / \mathrm{Ca}$ profile obtained along two parallel laser ablation transects in samples CO, MI, and RI, plotted against in-situ monthly seawater temperature records from 2003-2004 to 2008 from the T-MedNet project, and mean, maximum, and minimum temperatures sourced from the NOAA WOA13 database nearby the coral sampling locations. Figure 8 also shows the thickness of the light and dark bands for the corresponding years. 
Overall, the two laser-ablation transects for samples $\mathrm{CO}$ and $\mathrm{RI}$ display a clear cyclical $\mathrm{Mg} / \mathrm{Ca}$ pattern along both sides, which is not entirely the case for sample MI, showing less-defined variations, notably for the transect that is slightly offset from the mid-part of the transverse section (Fig. 8). However, the amplitudes of the $\mathrm{Mg} / \mathrm{Ca}$ cycles differ between the two transects and sides of the coral cross section at the corresponding year, and often don't match the amplitudes of the seawater temperature records. This most likely suggests that the finescale $\mathrm{Mg} / \mathrm{Ca}$ variability is only partially controlled by the seasonal temperature changes. Furthermore, the $\mathrm{Mg} / \mathrm{Ca}$ content of the alternating light and dark bands does not seem to relate to their thickness, even though $\mathrm{Mg} / \mathrm{Ca}$ is enriched in the thicker light bands (Fig. 7). The minimum, maximum, and mean $\mathrm{Mg} / \mathrm{Ca}$ values obtained by laser ablation ICP-MS along the annular zones of samples RI, CO, MI, and MS-43, correlate with the coldest, warmest, and mean annual temperatures at the sampling locations from the NOAA WOA13 database (Fig. 9A, Tab. S4, S5). The linear regression is:

$\mathrm{Mg} / \mathrm{Ca}(\mathrm{mmol} / \mathrm{mol})=2.89( \pm 0.59) \times \mathrm{T}\left({ }^{\circ} \mathrm{C}\right)+73.98( \pm 9.09)$

$\left(\mathrm{r}^{2}=0.72, \mathrm{p}\right.$-value $\left.<0.001, \mathrm{n}=12\right)$

The slope and intercept of the linear relationship and their respective errors were calculated using a weighted linear regression between seawater temperatures and $\mathrm{Mg} / \mathrm{Ca}$ values, considering both temperature and $\mathrm{Mg} / \mathrm{Ca}$ uncertainties (Thirumalai et al., 2011).

Figure $9 \mathrm{~A}$ also reports the $\mathrm{Mg} / \mathrm{Ca}$ values of the skeletal calcite precipitated during the summer and winter periods for sample $\mathrm{CO}$, together with the corresponding temperature data from $\mathrm{T}$ MedNet (Tab. S5). The weighted linear regression is:

$\mathrm{Mg} / \mathrm{Ca}(\mathrm{mmol} / \mathrm{mol})=1.09( \pm 0.07) \times \mathrm{T}\left({ }^{\circ} \mathrm{C}\right)+101.21( \pm 1.13)$

$\left(\mathrm{r}^{2}=0.95, \mathrm{p}\right.$-value $\left.<0.001, \mathrm{n}=7\right)$

Finally, the mean $\mathrm{Mg} / \mathrm{Ca}$ values, obtained from the entire laser ablation transect (annular plus medullar zones) for each coral sample were compared to values from the literature for Isididae and Coralliidae spanning a temperature range of 2.5 to $19.5^{\circ} \mathrm{C}$ (Vielzeuf et al., 2013; Yoshimura et al., 2011) (Fig. 9B). Overall, our data gave a slope of 2.39 and an intercept of $85.31 \mathrm{mmol} / \mathrm{mol}$, which are comparable to those of Vielzeuf et al. (2013; slope 2.23, intercept 
$92.10 \mathrm{mmol} / \mathrm{mol})$ spanning a similar temperature range $\left(13.6\right.$ to $\left.16.8{ }^{\circ} \mathrm{C}\right)$. The general temperature dependence of $\mathrm{Mg} / \mathrm{Ca}$ obtained by combining our data with those of Vielzeuf et al. (2013), and Yoshimura et al. (2011) is:

$\mathrm{Mg} / \mathrm{Ca}(\mathrm{mmol} / \mathrm{mol})=3.10 \pm 0.31 \times \mathrm{T}\left({ }^{\circ} \mathrm{C}\right)+72.93 \pm 4.71$

$\left(\mathrm{r}^{2}=0.77, \mathrm{p}\right.$-value $\left.<0.001, \mathrm{n}=31\right)$

The three equations indicate a strong relationship between $\mathrm{Mg} / \mathrm{Ca}$ and temperature, with more than $70 \%$ of the $\mathrm{Mg} / \mathrm{Ca}$ variance being explained by the temperature correlation. The slope and intercept of the general equation are identical (within error) to those obtained by Thresher et al. (2016) for Isididae (slope: $2.93 \pm 0.25$; intercept: $72.1 \pm 2.46)$ and Coralliidae (3.08 \pm 0.56

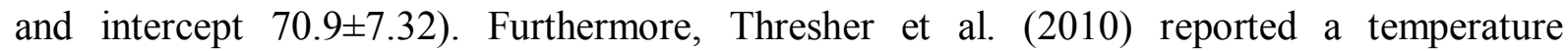
calibration for isidid corals with a slope of $0.048{ }^{\circ} \mathrm{C} / \mathrm{mmol} / \mathrm{mol}$ (equivalent to $\sim 21 \%$ change in $\mathrm{Mg} / \mathrm{Ca}$ for a $1{ }^{\circ} \mathrm{C}$ change).

If the dataset used to calculate the regression is restricted only to the Corallium genus (this study and data from Vielzeuf et al., 2013 and Yoshimura et al., 2011), the following equation is obtained:

$\mathrm{Mg} / \mathrm{Ca}(\mathrm{mmol} / \mathrm{mol})=3.71 \pm 0.23 \times \mathrm{T}\left({ }^{\circ} \mathrm{C}\right)+66.89 \pm 3.21$

$\left(\mathrm{r}^{2}=0.92, \mathrm{p}\right.$-value $\left.<0.001, \mathrm{n}=24\right)$

To test the reliability of our equations 2 and 4 and hence the fidelity of $\mathrm{Mg} / \mathrm{Ca}$ as a temperature proxy in C. rubrum, we have compared instrumental temperature records with the reconstructed temperatures across the last five annual increments of samples $\mathrm{CO}, \mathrm{MI}$, and RI (Fig. 10), and across a longer period for sample MI (Fig. 11). Overall, it seems that the $\mathrm{Mg} / \mathrm{Ca}$-derived temperature from equation 2 overestimates the real temperature and the seasonal amplitude is reduced or amplified depending both on the specific sample and the side of the coral used. The best match between reconstructed and instrumental temperature is observed for side 2 of sample $\mathrm{CO}$ (Fig. 10B). The $\mathrm{Mg} / \mathrm{Ca}$-derived temperature from equation 4 underestimates the absolute value for the summer months and the seasonal cycle. In general, the width of the peaks in warm seasons is larger than that in cold seasons (Fig. 10). The reconstructed temperature record using equations 2 and 4 derived from $\mathrm{Mg} / \mathrm{Ca}$ ratios 
across the last 30 growth bands of MI (Fig. 11), show different trends to that of the highresolution in situ temperatures measured from the sample location (Calvo et al., 2011; Salat and Pascual, 2002; T-MedNet network).

For the deep-water sample MS-43, the $\mathrm{Mg} / \mathrm{Ca}$ ratios across the last five annual increments have large variations $(>20 \mathrm{mmol} / \mathrm{mol}$ ) (Fig. 12A) and a more constant growth band width compared to the shallow specimens (Fig. 12B). Large $\mathrm{Mg} / \mathrm{Ca}$ fluctuations clearly contrast with the stable environmental conditions in the deep-waters offshore SW Malta. These translate to $\mathrm{Mg} / \mathrm{Ca}$-reconstructed temperature variations of $>5^{\circ} \mathrm{C}$ for the recent part (between 10.15 and $\left.16.36^{\circ} \mathrm{C}\right)$, which are much larger than ambient seawater temperature variability $( \pm$ $0.07^{\circ} \mathrm{C}$ ) (Fig. $\left.12 \mathrm{C}, 12 \mathrm{D}\right)$.

\section{Discussion}

\subsection{Skeletal structures of shallow- and deep-water Corallium}

The architecture observed in the shallow-water samples (Figs. 2-4) conforms fairly with previous observations on C. rubrum (e.g. Lacaze-Duthiers 1864; Vielzeuf et al., 2008; Vielzeuf et al., 2010; Floquet and Vielzeuf, 2011 \& 2012; Vielzeuf et al. 2013). In particular, the central fast-growing medullar zone appears surrounded by the slow-growing annular zone (Figs. 5A, 5B) (e.g. Allemand and Grillo, 1992; Vielzeuf et al., 2018). This distinct structure also occurs in our deep-water sample (MS-43), which is noticeably lighter in color, possibly reflecting different proportions of organic matrix to calcium carbonate within the skeleton. This is inferred by the differences in band color intensity when stained (OMS), with the darker portions corresponding to higher organic content (Figs. 2G, 2I). The light-red layers are apparently emplaced during spring and summer, while the relatively narrower dark-red bands correspond to fall and winter (Marschal et al. 2004), implying seasonal environmental controls on coral band growth. Additional coral samples are needed to support this hypothesis. Although temperature would be a likely driver of band growth in shallow water corals, we note that the same banding pattern occurs in the deep-water specimen MS-43 (Fig. 5B) calcifying in an essentially stable temperature regime (Fig. 12). Therefore, we hypothesize that seasonal fluctuations in food supply from superficial to bathyal depths (Brunet et al., 2006; Brunet et al., 2007; Houlbrèque et al., 2003), is more likely to control annual band emplacement. Further research with independent high spatial resolution age control (e.g. 
radiometric dating) is needed to calibrate growth rates of deep-water C. rubrum to determine whether the bands are deposited annually.

Although the internal micro-structures of the shallow and deep-water specimens are also similar, the significant differences in the size of the component fibers and blades (Figs. 4D, $4 \mathrm{G}-\mathrm{H})$ reflect the different growth rates of these structures. Prior studies that examined these microstructures in shallow-water C. rubrum at higher (sub-micron) resolution revealed that the principal component crystals comprise nano-grains (Alivisatos, 2000; Vielzeuf et al., 2008).

\subsection{Growth bands}

Coral ages are based on the results from organic staining (OMS method) which gave the most reliable chronologies, the resultant growth rates being consistent with the diameter to age relationship observed by Priori et al. (2013). The latest annual band portion in RI, MI and PF is a light-colored ring (Fig. 2), which corresponds to summer colony harvesting and supports the observations of growth ring emplacement proposed by Marschal et al. (2004). Benedetti et al. (2016) observed an ontogenetic decrease of radial extension rates, which is also present in specimens MS-43 and PF (Fig. 5). The fast growth rate of PF $(276 \pm 65 \mu \mathrm{m} / \mathrm{yr})$ reflects its location at intermediate depth where food availability and quality are highest between late winter and summer (Grémare et al., 1997; Rossi et al., 2003). Several studies have shown that C. rubrum populations inhabiting intermediate depths are able to capture larger amounts of nutrients than those in shallower waters (Tsounis et al., 2006), and experience a lower recruit mortality (Bramanti et al., 2005). In shallower waters, large colonies require more food to maintain a similar growth rate (Galli et al., 2016), with lower growth rates reflecting lower food availability compared to intermediate depth corals. The annual banding pattern in $C$. rubrum, thus likely reflects seasonal fluctuations in food supply (Marschal et al., 2004) rather than temperature-controlled growth. For RI and $\mathrm{MI}$, the $\sim 1^{\circ} \mathrm{C}$ average temperature increase over the last 30 years with more frequent heat waves (Salat and Pascual, 2002; Bensoussan et al., 2010; Calvo et al., 2011) is not correlated with band widths, and growth perturbations from heat induced mass-mortality events (Linares et al. 2005) were not observed. The OMSbased chronologies have thus been essential to temporally constrain the geochemical compositions, and ambient environment conditions. 


\subsection{Elemental composition}

The high-resolution laser ablation ICP-MS transects (Fig. 3) across the calcareous axial skeletons of C. rubrum reveal a large geochemical variability, with significant differences between the inner medullar and the outer annular regions (Tab. 3; Fig. 6). Overall, among the elements analyzed in the present study, $\mathrm{Mg}$ and $\mathrm{Sr}$ represent the most abundant elements in both shallow- and deep-water C. rubrum, followed by B/Ca, with the lowest abundance being $\mathrm{Li}$ and $\mathrm{Ba}$ (Tab. 3). The relative elemental abundance, with $\mathrm{Mg}>\mathrm{Sr}>\mathrm{B}>\mathrm{Li}>\mathrm{Ba}$, is the same in all five C. rubrum specimens irrespective of depth. The observations are consistent with prior studies on shallow-water Mediterranean C. rubrum (Weinbauer et al., 2000; Vielzeuf et al., 2013). Shallow-water specimens MI, RI and CO, systematically differ from the deep-water specimen MS-43 by having higher $\mathrm{Mg} / \mathrm{Ca}$ and $\mathrm{Li} / \mathrm{Ca}$, and lower $\mathrm{Ba} / \mathrm{Ca}$ (Tab. 3), possibly related to differences in seawater temperature and nutrient concentrations, whereas $\mathrm{Sr} / \mathrm{Ca}$ and $\mathrm{B} / \mathrm{Ca}$ show no systematic difference between sites. Beyond these average skeletal compositions (Tab. 3), all corals show systematic enrichment in $\mathrm{Mg}, \mathrm{Sr}$, and $\mathrm{Li}$ in their medullar zone relative to their annular zone (Figs. 6, 7, Tab. 3). The medullar zone corresponds to skeletal deposits at the growth tip of each branch and is precipitated within its first few years of fast growth (Vielzeuf et al., 2018), it is rich in organics and canals within the skeleton, and has no clear banding (Figs. 5, 7). Skeletal precipitation rates may therefore influence the relative elemental compositions of the fast-growing medullar and the comparatively slow-growing annular zones. Consequently, the declining $\mathrm{Mg} / \mathrm{Ca}, \mathrm{Sr} / \mathrm{Ca}$, and $\mathrm{Li} / \mathrm{Ca}$ compositions within the annular zone might also be considered a growth rate effect (Fig. 7). Notably, Priori et al. (2013) documented an ontogenetic decline of annual stem diameter accretion. However, our band width measurements in the annular zone do not consistently decrease ontogenetically, and the elemental compositions are not correlated with increment width (Tabs. 6, 7). We presume that ontogenetic trends in $\mathrm{Mg}$ may be partially related to increasing relative proportions in the organic matrix. Vielzeuf et al. (2013) noted an anticorrelation between $\mathrm{Mg}$ and $\mathrm{S}$ in $C$. rubrum as a possible function of $\mathrm{S}$ containing organic matter within the calcitic skeleton, which may also confound annual $\mathrm{Mg} / \mathrm{Ca}$ based temperature reconstructions (see below). Inter-annual and intra-annual variations in $\mathrm{Mg} / \mathrm{Ca}$ beyond the expected range of ambient temperature variability could reflect potential vital effect resulting from different growth rates. Strong kinetic vital effects have been documented in C. rubrum based on $\delta^{13} \mathrm{C}$ and $\delta^{18} \mathrm{O}$ from micro-milled transects from the same coral samples (Chaabane et al., 2016). These vital effects resemble those seen in scleractinian cold- 
water corals (e.g. Oppelt et al., 2017 and references therein), and document a strong control by coral tissue during the biomineralization process. Oxygen isotopes and stable carbon isotopes are linearly correlated to $\mathrm{Mg} / \mathrm{Ca}$ and $\mathrm{Li} / \mathrm{Ca}$ in aragonitic cold-water corals (Montagna et al. 2014), which likely relates to a common mineralization mechanism. $\mathrm{Li} / \mathrm{Mg}$ is used to correct for vital effects that results in reliable temperature reconstructions (e.g. Cuny-Guirriec et al., 2019 and references therein) from scleractinian cold-water corals, however, the $\mathrm{Li} / \mathrm{Mg}$ compositions in calcitic corals (e.g. isidid bamboo corals or C. rubrum) is not temperature dependent. Conversely, $\mathrm{Mg} / \mathrm{Ca}$ compositions have yielded reasonable temperature estimates for Isididae (Flöter et al. 2019 and references therein) and Corallidae (Yoshimura et al. 2011), as discussed below. $\mathrm{Sr} / \mathrm{Ca}$ covaries strongly with $\mathrm{Mg} / \mathrm{Ca}$ and also with $\mathrm{Li} / \mathrm{Ca}$ in the annular zone of all coral specimens, showing their dependence on the same biomineralization mechanism. Vielzeuf et al. (2018) proposed that Rayleigh fractionation controlled the linear relationship between $\mathrm{Sr} / \mathrm{Ca}$ and $\mathrm{Mg} / \mathrm{Ca}$. Further correlations between elements are given in Tabs. 4-6, for bulk skeleton, the medullar, and the annular zones.

The similarities in $\mathrm{Ba} / \mathrm{Ca}$ compositions between the medullar and annular zones indicate that this element is not affected by skeletal precipitation rates and may thus reflect changes in seawater $\mathrm{Ba}$ composition, as previously postulated by Vielzeuf et al. (2018). The $\mathrm{Ba} / \mathrm{Ca}$ compositions of calcitic bamboo corals correlate with seawater $\mathrm{Ba} / \mathrm{Ca}$ compositions, with the first calibration being reported by LaVigne et al. (2011). Flöter et al. (2018) also noted that the average $\mathrm{Ba} / \mathrm{Ca}$ composition of a bamboo coral from Blake Ridge agrees with instrumental seawater data, whereas the variability within bandings exceeded the variability of measured seawater $\mathrm{Ba}$ concentrations. Solution ICP-MS Ba/Ca data in C. rubrum range from 5.75 to $7.84 \mu \mathrm{mol} / \mathrm{mol}$ (Tab. 3), which would correspond to reconstructed seawater Ba concentrations of $\sim 20$ to $\sim 45 \mathrm{nmol} / \mathrm{kg}$ using the relationship of LaVigne et al. (2011). These reconstructions are below the lower end of the calibration range and are generally compatible with the oligotrophic conditions of the Mediterranean. Highest skeletal $\mathrm{Ba} / \mathrm{Ca}$ values are observed in MS-43 (Tab. 3, Fig. 6) and may indicate higher nutrient levels in bathyal Mediterranean settings. This pattern of increasing seawater $\mathrm{Ba}$ concentrations with depth has been documented in the Western Mediterranean by Van Beek et al. (2009).

\section{Intra-annual variability}

Close scrutiny of elemental variability along the laser-ablation transects reveals fine scale variability that corresponds to the banding pattern. Each annual band is comprised of a wide 
light band corresponding to spring and summer, and by a narrow dark band corresponding to fall and winter (e.g. Marschal et al. 2004). Summer bands show relatively high $\mathrm{Mg}$, Sr, and $\mathrm{Li}$, compared to winter bands suggesting a temperature driven annual signal. $\mathrm{Ba}$ is relatively low in summer bands, while B is similar in dark and light bands. The correlation between elements in the shallow water specimens (Tab. 4) and the deep-water specimen (Tab. 5) show similar patterns. Given that bathyal temperatures are stable, these correlations suggest that vital effects are also super-imposed on $\mathrm{Mg}, \mathrm{Sr}$, and Li signals at annual band scales.

\section{4. $\mathrm{Mg} / \mathrm{Ca}$ as temperature proxy}

$\mathrm{Mg} / \mathrm{Ca}$ compositions of bulk skeleton (solution ICP-MS data) and averaged in-situ (laserablation) measurements (Tab. 3) for both the shallow- (MI, RI, CO), intermediate- (PF) and deep-water (MS-43) specimens correspond to the average ambient seawater temperatures at each site (Figs. 1, 9; Tab. 1). Our $\mathrm{Mg} / \mathrm{Ca}$ values fall into the same range as the $\mathrm{Mg} / \mathrm{Ca}$ data of C. rubrum between 10 and $70 \mathrm{~m}$ depth reported by Vielzeuf et al. (2013), further supporting the veracity of solution ICP-MS based corrections applied to our laser-ablation elemental data. The slope of minima, means, and maxima $\mathrm{Mg} / \mathrm{Ca}$ versus minima, means, and maxima of annual ambient seawater temperatures (equation 1) is 2.89 for temperatures ranging between 13.81 and $17.34^{\circ} \mathrm{C}$, which is similar to the slope of 2.23 for 13.6 to $16.8^{\circ} \mathrm{C}$ obtained by Vielzeuf et al. (2013). Both datasets are compatible with the global temperature calibration of Corallidae and Isididae determined by Yoshimura et al. (2011), for temperatures between 2.5 and $19.5^{\circ} \mathrm{C}$ (Fig. 9B). When combining these three datasets, (equation 3), a slope of 3.10 (intercept $72.93 \mathrm{mmol} / \mathrm{mol}$ ) is obtained, compatible with the isidid temperature calibration determined by Thresher et al. (2016). Based on corals of the genus Corallium alone from the datasets of Yoshimura et al. (2011), Vielzeuf et al. (2013), and this study, equation 4 yields a slope of 3.71 and an intercept of $66.89 \mathrm{mmol} / \mathrm{mol}$. Overall, these equations indicate that temperature has a strong control on the $\mathrm{Mg} / \mathrm{Ca}$ compositions of Corallium, with more than $70 \%$ of the $\mathrm{Mg} / \mathrm{Ca}$ variance related to temperature (Fig. 9B). The potential for $\mathrm{Mg} / \mathrm{Ca}$ compositions of calcitic corals to serve as a temperature proxy has been suggested by others (Thresher et al., 2004; Thresher et al., 2007; Sherwood et al., 2005; Thresher et al., 2010), and more recent studies of bamboo corals (Thresher et al., 2016; Flöter et al., 2019) have shown that the innermost juvenile layers have significantly higher $\mathrm{Mg} / \mathrm{Ca}$ compositions than the skeletal bands precipitated during adult growth stages. These observations are analogous to the increased $\mathrm{Mg} / \mathrm{Ca}$ ratios of the medullar zone in juvenile C. rubrum (Figs. 6, 7) relative to 
the annular zone (see also Vielzeuf et al., 2013).

Different radial lengths of the annular zone due to the asymmetric growth around the stem are reflected by large scale changes in the $\mathrm{Mg} / \mathrm{Ca}$ laser profiles (Tabs. 6, 7). Notably, at individual band resolution, there is no correlation between $\mathrm{Mg} / \mathrm{Ca}$ and band thickness. This paradox is possibly due to varying contributions of $\mathrm{Mg}$ from the organic matrix (Vielzeuf et al. 2013). The contribution to $\mathrm{Mg} / \mathrm{Ca}$ signal from biological modification becomes apparent when considering the deep-water specimen MS-43 (Fig. 12) where ambient temperatures are essentially stable. Its $\mathrm{Mg} / \mathrm{Ca}$ amplitude of $\sim 25 \mathrm{mmol} / \mathrm{mol}$ for the last 5 years would result in reconstructed temperature variabilities of $\sim 4^{\circ} \mathrm{C}$ (Eq. 4), compared to the measured range of $\sim 0.5^{\circ} \mathrm{C}$. Similarly, the amplitudes of $\mathrm{Mg} / \mathrm{Ca}$ of $\sim 10$ to $\sim 25 \mathrm{mmol} / \mathrm{mol}$ for the last 5 years in RI, MI, and CO, do not correspond to the systematic difference in intra-annual ambient seawater temperatures at these sites (Fig. 1; Tabs. 1, S1).

\section{Intra-annual Mg/Ca variability}

Given the overall strong relationship between seawater temperature and $\mathrm{Mg} / \mathrm{Ca}$ compositions of Corallidae from a wide depth and temperature range (Fig. 9B), we further investigated this relationship at inter-annual and seasonal scales. When applying equations 1,3 , and 4 to $\mathrm{Mg} / \mathrm{Ca}$ records along each laser ablation transect within the annular zone, the apparent $\mathrm{Mg} / \mathrm{Ca}$-temperature relationship breaks down. Equation 4 yields gross underestimations (Fig. 11) of the temperature ranges at each site, and is significantly biased by ontogenetic effects reflected by decreasing $\mathrm{Mg} / \mathrm{Ca}$ trends (Figs. 6, 7). Direct comparison of temperature logger data with the corresponding $\mathrm{Mg} / \mathrm{Ca}$ record for the years 2003 to 2008 (Tab. 8) yielded an ambiguous result (Figs. 8, 10). In all three shallow-water colonies (MI, RI, and CO), the $\mathrm{Mg} / \mathrm{Ca}$ cycles within each band are typically in phase with the seawater temperature cycles recorded at each site. The lack of correlation (Fig. 9A) of $\mathrm{Mg} / \mathrm{Ca}$ with ambient temperature at inter-annual and intra-annual resolution is largely due to strong biological controls on skeletal precipitation. Lack of correlation is also a result of an inadequate age-model, which distributes time linearly within increments. While $\mathrm{Mg} / \mathrm{Ca}$ signals are in phase with annual cycles, the growth rate varies throughout the seasonal cycle with slower growth in winter and faster growth in summer. For these reasons, Equation 2 has a slope of only 1.09 and leads to gross overestimations of past ambient temperatures (Fig. 11). All specimens from deep and shallow sites exhibit a decline in $\mathrm{Mg} / \mathrm{Ca}$ compositions from the inner part of the stem to the outer youngest layers (Fig. 7). This pattern affects also the logger-based calibration, which 
only accounts for the last 5 years of growth. Thus, future investigations that accommodate varying intra-annual accretion rates and correct for the biological (including ontogenetic) $\mathrm{Mg} / \mathrm{Ca}$ contributions, would likely obtain more realistic temperature reconstructions from $C$. rubrum.

\section{Conclusions}

1. The deep-water colony of C. rubrum shows internal microstructures similar to shallow-water specimens at other locations. There is a clear distinction between the internal medullar area and an external annular zone in both shallow and deepwater specimens. Furthermore, the deep-water sample shows a large zone with intermediate characteristics, and has thinner and more regular annular growth rings compared to the shallow-water corals. These growth features reveal the sensitivity of $C$. rubrum to their environmental conditions, being near stable at depth which contrasts to the large seasonal fluctuation characteristic of shallow waters.

2. Laser geochemical profiles across the skeletons show large variability and significant differences between the inner medullar and outer annular regions. Compositions of the deep-water sample are less variable than the shallow water samples. $\mathrm{Mg} / \mathrm{Ca}$ ratios are significantly correlated with $\mathrm{Sr} / \mathrm{Ca}$ and $\mathrm{Li} / \mathrm{Ca}$, which suggests that the incorporation of these elements is controlled by similar mechanisms, such as growth rate (kinetic effects); conversely, $\mathrm{B} / \mathrm{Ca}$ and $\mathrm{Ba} / \mathrm{Ca}$ seem to be independent of growth rate. Element/Ca ratios show varying degrees of correlation with growth bands, especially $\mathrm{Mg} / \mathrm{Ca}$, for which the depleted zones (low peaks) match dark growth bands and Mg-enriched cycles (high peaks) correlate with bright bands.

3. The mean $\mathrm{Mg} / \mathrm{Ca}$ ratios of both shallow and deep-water specimens appear to be temperature dependent. Nevertheless, we could not reconstruct reliable interannual and seasonal $\mathrm{Mg} / \mathrm{Ca}$-derived temperature time-series given the amplitudes are inconsistent with the range in ambient seawater temperatures. Thus, other factors such as kinetic effects (e.g. growth rate) perturb the $\mathrm{Mg} / \mathrm{Ca}$-temperature relationship.

\section{Acknowledgements}


This work was funded by the EU-FP7 "Mediterranean Sea Acidifcation in a changing climate" project (MedSeA; grant agreement 265103), the CALMED project (CTM201679547-R), the AGAUR Generalitat de Catalunya (MERS, 2017 SGR 1588) and by the ENVIMED program. It is also a contribution to the EU F.P. VII Projects COCONET (contract no. 287844) and EVER-EST (contract no. 674907), the DG Environment programme IDEM (grant agreement No 11.0661/2017/ 750680/SUB/EN V.C2), the ICTA "Unit of Excellence" (MinECo, MDM2015-0552) and the Flag Project Ritmare (Ricerca Italiana per il Mare). We acknowledge captain, crew and scientifc party aboard R/V Urania during cruise MARCOS, with special thanks to L. Angeletti. Solution quadrupole ICP-MS analyses were performed with the assis- tance of L. Bordier at CNRS-LSCE, Gif-sur-Yvette, France. L. Gordon at UAB, Spain, and B. Leipner-Mata at GZN, Germany kindly helped with thin-section preparation. J. Garrabou, F. Zuberer and N. Bensoussan generously provided temperature data from the OSU Pytheas and T- MedNet network. S.Chaabane is grateful to E. Escuer Vilà for her help and support. M. McCulloch acknowledges fnancial support from the ARC Centre of Excellence for Coral Reef Studies (CE140100020) and J. Trotter acknowledges ARC Future Fellowship funding (FT160100259). This is ISMAR-CNR Bologna scientifc contribution n. 1977 and LSCE contribution number 6701

\section{References}

Abbiati, M., Costantini, F., Rugiu, L, Carlesi, L., 2015. Genetic connectivity and conservation in the long-lived harvested species Corallium rubrum. Proc. 2nd Mediterranean Symposium on conservation of coralligenous \& other calcareous bioconcretions (Portorož, Slovenia, 29-30 October 2014), pp 25-30.

Alivisatos, A.P., 2000. Naturally aligned nanocrystals. Science. 289, 736-737.

Allemand, D., Grillo, M.-C., 1992. Biocalcification mechanism in gorgonians: ${ }^{45}$ Ca uptake and deposition by the Mediterranean red coral Corallium rubrum. J. Exp. Zool. 262, 237-246. doi:10.1002/jez.1402620302

Barrier, P., Zibrowius, H., Lozouet, P., Montenat, C., Ott D’Estevou, P., Serrano, F., Soudet, H.J., 1991. Une faune de fond dur du bathyal supérieur dans le Miocène terminal des Cordillères Bétiques (Carboneras, SE, Espagne). Mésogée 51, 3-13.

Beck, J.W., Edwards, R.L., Ito, E., Taylor, F.W., Recy, J., Rougerie, F., Joannot, P., Henin, C., 1992. Sea-surface temperature from coral skeletal Strontium/Calcium ratios. Science. 257, 644-647.

Benedetti, M.C., Priori, C., Erra, F., Santangelo, G., 2016. Growth patterns in mesophotic octocorals: Timing the branching process in the highly-valuable Mediterranean Corallium rubrum. Estuar. Coast. Shelf Sci. 171, 106-110. doi:10.1016/j.ecss.2015.12.026

Bensoussan, N., Romano, J.C., Harmelin, J.G., Garrabou, J., 2010. High resolution 
characterization of northwest Mediterranean coastal waters thermal regimes: To better understand responses of benthic communities to climate change. Estuar. Coast. Shelf Sci. 87, 431-441. doi:10.1016/j.ecss.2010.01.008

Bindoff, N.L., Willebrand, J., Artale, V., Cazenave, A., Gregory, J.M., Gulev, S., Hanawa, K., Le Quéré, C., Levitus, S., Nojiri, Y., others, 2007. Observations: oceanic climate change and sea level. Obs. Ocean. Clim. Chang. sea level. Solomon, S., Qin, D., Manning, M., Chen, Z., Marquis, M., Averyt, K.B., Tignor, M., Mille, H.L. (Eds.), Clim. Chang. 2007 Phys. Sci. Basis, Intergov. Panel Clim. Chang. Cam 385-432.

Boyer, T.P., Antonov, J.I., Baranova, O.K., Coleman, C., Garcia, H.E., Grodsky, A., Johnson, D.R., Locarnini, R.A., Mishonov, A.V, Brien, T.D.O., Paver, C.R., Reagan, J.R., Seidov, D., Smolyar, I.V., Zweng, M.M., Sullivan, K.D., 2013. In: Mishonoc, A. (ed.) World Ocean Database 2013. Sydney Levitus, Tech. Ed. NOAA Atlas, 209 pp. doi:10.7289/V5NZ85MT

Brahmi, C., Kopp, C., Domart-Coulon, I., Stolarski, J., Meibom, A., 2012. Skeletal growth dynamics linked to trace-element composition in the scleractinian coral Pocillopora damicornis. Geochim. Cosmochim. Acta 99, 146-158. doi:10.1016/j.gca.2012.09.031

Bramanti, L., Magagnini, G., De Maio, L., Santangelo, G., 2005. Recruitment, early survival and growth of the Mediterranean red coral Corallium rubrum (L. 1758), a 4-year study. J. Exp. Mar. Bio. Ecol. 314, 69-78. doi:10.1016/j.jembe.2004.08.029

Bramanti, L., Movilla, J., Guron, M., Calvo, E., Gori, A., Dominguez-Carrié, C., Grinyo, J., Lopez-Sanz, A., Martinez-Quintana, A., Pelejero, C., Ziveri, P., Rossi, S., 2013. Detrimental effects of ocean acidification on the economically important Mediterranean red coral (Corallium rubrum). Glob. Chang. Biol. 19, 1897-1908. doi: $10.1111 / \mathrm{gcb} .12171$

Brunet, C., Casotti, R., Vantrepotte, V., Conversano, F., 2007. Vertical variability and diel dynamics of picophytoplankton in the Strait of Sicily, Mediterranean Sea, in summer. Mar. Ecol. Prog. Ser. 346, 15-26. doi:10.3354/meps07017

Brunet, C., Casotti, R., Vantrepotte, V., Corato, F., Conversano, F., 2006. Picophytoplankton diversity and photoacclimation in the Strait of Sicily (Mediterranean Sea) in summer. I. Mesoscale variations. Aquat. Microb. Ecol. 44, 127-141.

Burrows, M.T., Schoeman, D.S., Buckley, L.B., Moore, P., Poloczanska, E.S., Brander, K.M., Brown, C., Bruno, J.F., Duarte, C.M., Halpern, B.S., Holding, J., Kappel, C.V., Kiessling, W., O'Connor, M.I., Pandolfi, J.M., Parmesan, C., Schwing, F.B., Sydeman, W.J., Richardson, A.J., 2011. The pace of shifting climate in marine and terrestrial ecosystems. Science. 334, 652-655. doi:10.1126/science.1210288

Calvo, E., Simó, R., Coma, R., Ribes, M., Pascual, J., Sabatés, A., J.M., G., Pelejero, C., 2011. Effects of climate change on Mediterranean marine ecosystems: the case of the Catalan Sea. Clim. Res. 50, 1-29.

Cau, A., Follesa, M.C.,Moccia, D., Alvito, A., Bo, M., Angiolillo, M., Canese, S., Paliaga, E.M., Orrù, P.E., Sacco, F., Cannas, R., 2015. Deepwater corals biodiversity along roche du large ecosystems with different habitat complexity along the south Sardinia continental margin (CW Mediterranean Sea). Mar. Biol. 162, 1865-1878. doi: $10.1007 / \mathrm{s} 00227-015-2718-5$

Cerrano, C., Cardini, U., Bianchelli, S., Corinaldesi, C., Pusceddu, A., Danovaro, R., 2013. Red coral extinction risk enhanced by ocean acidification. Sci. Rep. 3, 1-7. doi: $10.1038 /$ srep01457

Chaabane, S., López Correa, M., Montagna, P., Kallel, N., Taviani, M., Linares, C., Ziveri, P., 2016. Exploring the oxygen and carbon isotopic composition of the Mediterranean red 
coral (Corallium rubrum) for seawater temperature reconstruction. Mar. Chem. 186, $11-$ 23. doi:10.1016/j.marchem.2016.07.001

Chave, K.E., 1954. Aspects of the biogeochemistry of Magnesium. 1. Calcareous Marine Organisms. J. Geol. 62, 266-283. doi:10.1086/626162

Coma, R., Ribes, M., Gili, J.-M., Zabala, M., 2002. Seasonality of in situ respiration rate in three temperate benthic suspension feeders. Limnol. Oceanogr. 47, 324-331. doi: $10.4319 /$ lo.2002.47.1.0324

Conversi, A., Umani, S.F., Peluso, T., Molinero, J.C., Santojanni, A., Edwards, M., 2010. The Mediterranean Sea regime shift at the end of the 1980s, and intriguing parallelisms with other European basins. PlosOne 5, 1-15. doi:10.1371/journal.pone.0010633

Corrège, T., 2006. Sea surface temperature and salinity reconstruction from coral geochemical tracers. Palaeogeogr. Palaeoclimatol. Palaeoecol. 232, 408-428. doi:10.1016/j.palaeo.2005.10.014

Costantini, F., Taviani, M., Remia, A., Pintus, E., Schembri, P.J., Abbiati, M., 2010. Deepwater Corallium rubrum (L., 1758) from the Mediterranean Sea: Preliminary genetic characterisation. Mar. Ecol. 31, 261-269. doi:10.1111/j.1439-0485.2009.00333.x

Cuny-Guirriec, K., Douville, E., Reynaud, S., Allemand, D., Bordier, L., Canesi, M., Mazzoli, C., Taviani, M., Canese, S., McCulloch, M., Trotter, J., Rico-Esenaro, S.D., SanchezCabeza, J.-A., Ruiz-Fernández, A.C., Carricart-Ganivet, J.P., Scott, P., Sadekov, A., Montagna, P., 2019. Coral Li/Mg thermometry: Caveats and constraints. Chemical Geology (in press). doi:10.1016/j.chemgeo.2019.03.038

Dauphin, Y., 2006. Mineralizing matrices in the skeletal axes of two Corallium species (Alcyonacea). Comp. Biochem. Physiol. A Mol. Integr. Physiol. 145, 54-64. doi:10.1016/j.cbpa.2006.04.029

Della Croce, N., Fabiano, M., Zunin Sertorio, T., 1979. Biomassa planctonica sali nutritivi, parametri idrologici (Chiavari): Ottobre 1977-Ottobre 1978. Catt. Idrobiol. Pesc. Univ. Genova, Rapp. Techn.8, 1-14

Di Geronimo, S., Rosso, A., Sanfilippo, R., 1993. The Corallium rubrum fossiliferous banks off Sciacca (Strait of Sicily). In: Cicogna, F., Cattaneo-Vietti, R., (eds) Il Corallo Rosso in Mediterraneo: Arte. Stor. e Sci. 75-107.

Diffenbaugh, N.S., Pal, J.S., Giorgi, F., Gao, X., 2007. Heat stress intensification in the Mediterranean climate change hotspot. Geophys. Res. Lett. 34, 1-6. doi:10.1029/2007GL030000

Douville, E., Paterne, M., Cabioch, G., Louvat, P., Gaillardet, J., Ayliffe, L., 2010. Abrupt sea surface $\mathrm{pH}$ change at the end of the Younger Dryas in the central sub-equatorial Pacific inferred from boron isotope abundance in corals (Porites). Biogeosciences 7, 2445-2459. doi: $10.5194 /$ bg-7-2445-2010

Dubois-Dauphin, Q., Montagna, P., Siani, G., Douville, E., Wienberg, C., Hebbeln, D., Liu, Z., Kallel, N., Dapoigny, A., Revel, M., Pons-Branchu, E., Taviani, M., Colin, C., 2017. Hydrological variations of the intermediate water masses of the western Mediterranean Sea during the past $20 \mathrm{ka}$ inferred from neodymium isotopic composition in foraminifera and cold-water corals. Clim. Past 13, 17-37. doi:10.5194/cp-13-17-2017

Fink, H.G., Wienberg, C., De Pol-Holz, R., Hebbeln, D., 2015. Spatio-temporal distribution patterns of Mediterranean cold-water corals (Lophelia pertusa and Madrepora oculata) during the past 14,000 years. Deep. Res. Part I 103, 37-48. doi:10.1016/j.dsr.2015.05.006

Fink, H.G., Wienberg, C., De Pol-Holz, R., Wintersteller, P., Hebbeln, D., 2013. Cold-water 
coral growth in the Alboran Sea related to high productivity during the Late Pleistocene and Holocene. Mar. Geol. 339, 71-82. doi:10.1016/j.margeo.2013.04.009

Flöter, S. Fietzke, J., Gutjahr, M., Farmer, J., Hönisch, B., Nehrke, G., Eisenhauer, A., 2019. The influence of skeletal micro-structures on potential proxy records in a bamboo coral. Geochimica et Cosmochimica Acta 248, 43-60; doi:10.1016/j.gca.2018.12.027

Floquet, N., Vielzeuf, D., 2012. Ordered misorientations and preferential directions of growth in mesocrystalline red coral sclerites. Cryst. Growth Des. 12, 4805-4820. doi: $10.1021 / \operatorname{cg} 300528 \mathrm{~h}$

Floquet, N., Vielzeuf, D., 2011. Mesoscale twinning and crystallographic registers in biominerals. Am. Mineral. 96, 1228-1237. doi:10.2138/am.2011.3805

Flöter, S., Fietzke, J., Gutjahr, M., Farmer, J., Hönisch, B., Nehrke, G., Eisenhauer, A., 2018. The influence of skeletal micro-structures on potential proxy records in a bamboo coral. Geochim. Cosmochim. Acta 248, 43-60. doi:10.1016/j.gca.2018.12.027

Freiwald, A., Beuck, L., Rüggeberg, A., Taviani, M., Hebbeln, D., 2009. The white coral community in the central Mediterranean Sea revealed by ROV surveys. Oceanography 22, 58-74. doi:10.5670/oceanog.2009.06

Gagan, M.K., Ayliffe, L.K., Beck, J.W., Cole, J.E., Druffel, E.R.M., Dunbar, R.B., Schrag, D.P., 2000. New views of tropical paleoclimates from corals. Quat. Sci. Rev. 19, 45-64. doi:10.1016/S0277-3791(99)00054-2

Galli, G., Bramanti, L., Priori, C., Rossi, S., Santangelo, G., Tsounis, G., Solidoro, C., 2016. Modelling red coral (Corallium rubrum) growth in response to temperature and nutrition. Ecol. Modell. 337, 137-148. doi:10.1016/j.ecolmodel.2016.06.010

Giorgi, F., 2006. Climate change hot-spots. Geophys. Res. Lett. 33, 1-4. doi:10.1029/2006GL025734

Grémare, A., Amouroux, J.M., Charles, F., Dinet, A., Riaux-Gobin, C., Baudart, J., Medernach, K., Bodiou, J.Y., Vetion, G., Colomines, J.C., Albert, P., 1997. Temporal changes in the biochemical composition and nutritional value of the particulate organic matter available to surface deposit-feeders: a two year study. Mar. Ecol. Prog. Ser. 150, 195-206. doi:10.3354/meps 150195

Gattuso, J.-P., Alliouane, S., Mousseau, L., 2017. Seawater carbonate chemistry in the Bay of Villefranche, Point B (France), January 2007-December 2016. PANGAEA, https://doi.org/10.1594/PANGAEA.727120

Hasegawa, H., Rahman, M.A., Luan, N.T., Maki, T., Iwasaki, N., 2012. Trace elements in Corallium spp. as indicators for origin and habitat. J. Exp. Mar. Bio. Ecol. 414-415, 1-5. doi:10.1016/j.jembe.2012.01.005

Hathorne, E.C., Felis, T., Suzuki, A., Kawahata, H., Cabioch, G., 2013. Lithium in the aragonite skeletons of massive Porites corals: A new tool to reconstruct tropical sea surface temperatures. Paleoceanography 28, 143-152. doi:10.1029/2012PA002311

Hill, T.M., LaVigne, M., Spero, H.J., Guilderson, T., Gaylord, B., Clague, D., 2012. Variations in seawater $\mathrm{Sr} / \mathrm{Ca}$ recorded in deep-sea bamboo corals. Paleoceanography 27, 5-11. doi:10.1029/2011PA002260

Houlbrèque, F., Tambutté, E., Ferrier-Pagès, C., 2003. Effect of zooplankton availability on the rates of photosynthesis, and tissue and skeletal growth in the scleractinian coral Stylophora pistillata. J. Exp. Mar. Bio. Ecol. 296, 145-166. doi:10.1016/S00220981(03)00259-4

Kimball, J., Eagle, R., Dunbar, R., 2016. Carbonate "clumped" isotope signatures in aragonitic scleractinian and calcitic gorgonian deep-sea corals. Biogeosciences 13, 6487- 
6505. doi:10.5194/bg-13-6487-2016

Knittweis, L., Aguilar, R., Alvarez, H., Borg, J.A., Evans, J., Garcia, S., Schembri, P.J., 2016. New depth record of the precious red coral Corallium rubrum for the Mediterranean, in: Rapp. Congr. Comm. Intern. Expl. Scient. Mer Médit., Monaco, CIESM 41. p. 467.

Lacaze-Duthiers, H., 1864. Histoire naturelle du corail: organisation, reproduction, pêche en Algérie, industrie et commerce. J.-B. Baillière et fils.

Le Goff, C., Tambutté, E., Venn, A.A., Techer, N., Allemand, D., Tambutté, S., 2017. In vivo $\mathrm{pH}$ measurement at the site of calcification in an octocoral. Sci. Rep. 7, 1-14. doi:10.1038/s41598-017-10348-4

Linares, C., Coma, R., Diaz, D., Zabala, M., Hereu, B., Dantart, L., 2005. Immediate and delayed effects of a mass mortality event on gorgonian population dynamics and benthic community structure in the NW Mediterranean Sea. Mar. Ecol. Prog. Ser. 305, 127-137. doi: $10.3354 /$ meps 305127

Linares, C., Bianchimani, O., Torrents, O., Marschal, C., Drap, P., Garrabou, J., 2010. Marine Protected Areas and the conservation of long-lived marine invertebrates: The Mediterranean red coral". Mar. Ecol. Progr Ser 402, 69-79. doi:10.3354/meps0843

Linnaeus, C., 1758. Systema naturae per regna tria naturae, secundum classes, ordines, genera, species, cum characteribus, differentiis, synonymis, locis. Regnum Animale, 10th ed. Lipsiae.

Lodolo, E., Sanfilippo, R., Rajola, G., Canese, S., Andaloro, F., Montagna, P., Rosso, A., Macaluso, D., Di Geronimo, I., Caffau, M., 2017. The red coral deposits of the Graham Bank area: Constraints on the Holocene volcanic activity of the Sicilian Channel. GeoResJ 13, 126-133. doi:10.1016/j.grj.2017.04.003

López Correa, M., Montagna, P., Vendrell-Simón, B., McCulloch, M., Taviani, M., 2010. Stable isotopes $\left(\delta^{18} \mathrm{O}\right.$ and $\left.\delta^{13} \mathrm{C}\right)$, trace and minor element compositions of Recent scleractinians and Last Glacial bivalves at the Santa Maria di Leuca deep-water coral province, Ionian Sea. Deep-Sea. Res. Part II Top. Stud. Ocean. 57, 471-486. doi:10.1016/j.dsr2.2009.08.016

Marschal, C., Garrabou, J., Harmelin, J.G., Pichon, M., 2004. A new method for measuring growth and age in the precious red coral Corallium rubrum (L.). Coral Reefs 23, 423432. doi: 10.1007/s00338-004-0398-6

McCulloch, M., Falter, J., Trotter, J., Montagna, P., 2012. Coral resilience to ocean acidification and global warming through $\mathrm{pH}$ up-regulation. Nat. Clim. Chang. 2, 623627. doi:10.1038/nclimate 1473

McCulloch, M., Taviani, M., Montagna, P., López Correa, M., Remia, A., Mortimer, G., 2010. Proliferation and demise of deep-sea corals in the Mediterranean during the Younger Dryas. Earth Planet. Sci. Lett. 298, 143-152. doi:10.1016/j.eps1.2010.07.036

MEDAR Group, 2012. Physical oceanography measured on water bottle samples during several Ernest Krenkel cruises in 1976. doi:10.1594/PANGAEA.801836

MEDAR Group, 2006. Water temperature MBT profiles from cruise FS90198820400. doi:10.1594/PANGAEA.552157

Mitsuguchi, T., Matsumoto, E., Abe, O., Uchida, T., Isdale, P.J., 1996. Mg/Ca thermometry in coral skeletons. Science. 274, 961-963. doi:10.1126/science.274.5289.961

Montagna, P., Taviani, M., 2019. Mediterranean Cold-Water Corals as Paleoclimate Archives. In: Orejas, C, Jiménez C (eds), Mediterranean Cold-Water Corals: Past, Present and Future, Coral Reefs of the World 9, Springer International Publishing AG, part of Springer Nature. pp 105-118. doi.org/10.1007/978-3-319-91608-8_11 
Morel, J. P., 2000. Le corail dans l'Occident phénico-punique. In: Morel, JP, Rondi-Costanzo, C, Ugolini, D (eds). Corallo di ieri, corallo di oggi, Atti del convegno, Ravello, Villa Rufolo,13-15 dicembre 1996, pp. 121-134.

Montagna, P., McCulloch, M., Douville, E., López Correa, M., Trotter, J., Rodolfo-Metalpa, R., Dissard, D., Ferrier-Pagès, C., Frank, N., Freiwald, A., Goldstein, S., Mazzoli, C., Reynaud, S., Rüggeberg, A., Russo, S., Taviani, M., 2014. Li/Mg systematics in scleractinian corals: Calibration of the thermometer. Geochim. Cosmochim. Acta 132, 288-310. doi:10.1016/j.gca.2014.02.005

Montagna, P., McCulloch, M., Mazzoli, C., Silenzi, S., Odorico, R., 2007. The non-tropical coral Cladocora caespitosa as the new climate archive for the Mediterranean: highresolution (weekly) trace element systematics. Quat. Sci. Rev. 26, 441-462. doi:10.1016/j.quascirev.2006.09.008

Montagna, P., McCulloch, M., Taviani, M., Mazzoli, C., Vendrell, B., 2006. Phosphorus in cold-water corals as a proxy for seawater nutrient chemistry. Science. 312, 1788-1791. doi:10.1126/science. 1125781

Montagna, P., McCulloch, M., Taviani, M., Remia, A., Rouse, G., 2005. High-resolution trace and minor element compositions in deep-water scleractinian corals (Desmophyllum dianthus) from the Mediterranean Sea and the Great Australian Bight. In: Freiwald A, Roberts JM (eds), Cold-water Corals and Ecosystems., in: Springer-Verlag Cold-Water Corals and Ecosystems, Berlin Heidelberg. pp. 1109-1126. doi:10.1007/3-540-27673-4

Morse, J.W., Arvidson, R.S., Lüttge, A., 2007. Calcium carbonate formation and dissolution. Chem. Rev. 107, 342-381. doi:10.1021/cr050358j

Mucci, A., 1987. Influence of temperature on the stability of magnesian calcite. Am. Mineral. 51, 1977-1984. doi:10.1016/0016-7037(87)90186-4

Oppelt, A., López Correa, M., Rocha, C., 2017. Biogeochemical analysis of the calcification patterns of cold-water corals Madrepora oculata and Lophelia pertusa along contact surfaces with calcified tubes of the symbiotic polychaete Eunice norvegica: evaluation of a 'mucus' calcification hypothesis. Deep-Sea Research Part I 127, 90-104.

Peirano, A., Morri, C., Bianchi, C.N., Aguirre, J., Antonioli, F., Calzetta, G., Carobene, L., Mastronuzzi, G., Orru, P., 2004. The Mediterranean coral Cladocora caespitosa: a proxy for past climate fluctuations? Glob. Planet. Change 40, 195-200. doi:10.1016/S09218181(03)00110-3

Pelejero, C., Calvo, E., McCulloch, M.T., Marshall, J.F., Gagan, M.K., Lough, J.M., Opdyke, B.N., 2005. Preindustrial to modern interdecadal variability in coral reef $\mathrm{pH}$. Science 309, 2204-2207. doi:10.1126/science. 1113692

Perrin, J., Rivard, C., Vielzeuf, D., Laporte, D., Fonquernie, C., Ricolleau, A., Cotte, M., Floquet, N., 2017. The coordination of sulfur in synthetic and biogenic Mg calcites: The red coral case. Geochim. Cosmochim. Acta 197, 226-244. doi:10.1016/j.gca.2016.10.017

Perrin, J., Vielzeuf, D., Ricolleau, A., Dallaporta, H., Valton, S., Floquet, N., 2015. Block-byblock and layer-by-layer growth modes in coral skeletons. Am. Mineral. 100, 681-695. doi:10.2138/am-2015-4990

Picheral, M., Searson, S., Taillandier, V., Bricaud, A., Boss, E., Ras, J., Claustre, H., Ouhssain, M., Morin, P., Coppola, L., Gattuso, J.-P., Metzl, N., Thuillier, D., Gorsky, G., Tara Oceans Consortium, C., Tara Oceans Expedition, P., 2014. Vertical profiles of environmental parameters measured on discrete water samples collected with Niskin bottles at station TARA_210 during the Tara Oceans expedition 2009-2013. doi:10.1594/PANGAEA.839342 
Raitsos, D.E., Beaugrand, G., Georgopoulos, D., Zenetos, A., Pancucci-Papadopoulou, A.M., Theocharis, A., Papathanassiou, E., 2010. Global climate change amplifies the entry of tropical species into the Eastern Mediterranean Sea. Limnol. Oceanogr. 55, 1478-1484. doi: $10.4319 /$ lo.2010.55.4.1478

Ries, J.B., 2010. Review: Geological and experimental evidence for secular variation in seawater $\mathrm{Mg} / \mathrm{Ca}$ (calcite-aragonite seas) and its effects on marine biological calcification. Biogeosciences 7, 2795-2849. doi:10.5194/bg-7-2795-2010

Rossi, S., Grémare, A., Gili, J.M., Amouroux, J.M., Jordana, E., Vétion, G., 2003. Biochemical characteristics of settling particulate organic matter at two north-western Mediterranean sites: A seasonal comparison. Estuar. Coast. Shelf Sci. 58, 423-434. doi:10.1016/S0272-7714(03)00108-2

Rossi, S., Snyder, M.J., Gili, J.M., 2006. Protein, carbohydrate, lipid concentrations and HSP 70-HSP 90 (stress protein) expression over an annual cycle: Useful tools to detect feeding constraints in a benthic suspension feeder. Helgol. Mar. Res. 60, 7-17. doi:10.1007/s10152-005-0009-0

Rossi, S., Tsounis, G., Orejas, C., Padrón, T., Gili, J.M., Bramanti, L., Teixidó, N., Gutt, J., 2008. Survey of deep-dwelling red coral (Corallium rubrum) populations at Cap de Creus (NW Mediterranean). Mar. Biol. 154, 533-545. doi:10.1007/s00227-008-0947-6

Rueda, J.L., Urra, J., Aguilar, R., Angeletti, L., Bo, M., García-Ruiz, C., González-Duarte, M.M., López, E., Madurell, T., Maldonado, M., Mateo-Ramírez, Á., Megina,C., Moreira, J., Moya, F., Ramalho, L., Rosso, A., Sitjá, C., Taviani M., 2019. Cold-Water Coral Associated Fauna in the Mediterranean Sea and Adjacent Areas. In: Orejas, C, Jiménez C (eds), Mediterranean Cold-Water Corals: Past, Present and Future, Coral Reefs of the World 9, Springer International Publishing AG, part of Springer Nature. pp 105-118. doi.org/10.1007/978-3-319-91608-8_29

Salat, J., Pascual, J., 2002. The oceanographic and meteorological station at l'Estartit (NW Mediterranean), in: Millot, C. \& Briand, F. (eds.) Tracking Long-Term Hydrological Change in the Mediterranean Sea, CIESM Workshop Series 16, 29-32.

Schneider, C.A., Rasband, W.S., Eliceiri, K.W., 2012. NIH Image to ImageJ: 25 years of image analysis. Nat. Methods 9, 671-675. doi:10.1038/nmeth.2089

Sherwood, O.A., Heikoop, J.M., Sinclair, D.J., Scott, D.B., Risk, M.J., Shearer, C., AzetsuScott, K., 2005. Skeletal Mg/Ca in Primnoa resedaeformis: relationship to temperature? in: Freiwald, A., Roberts, J.M., Cold-Water Corals and Ecosystems. 1061-1079. doi:10.1007/3-540-27673-4_53

Shinjo, R., Asami, R., Huang, K., You, C., Iryu, Y., 2013. Ocean acidification trend in the tropical North Pacific since the mid- $20^{\text {th }}$ century reconstructed from a coral archive. Mar. Geol. 342, 58-64. doi:10.1016/j.margeo.2013.06.002

Silenzi, S., Bard, E., Montagna, P., Antonioli, F., 2005. Isotopic and elemental records in a non-tropical coral (Cladocora caespitosa): Discovery of a new high-resolution climate archive for the Mediterranean Sea. Glob. Planet. Change 49, 94-120. doi:10.1016/j.gloplacha.2005.05.005

Sinclair, D.J., Kinsley, L., McCulloch, M.T., 1998. High resolution analysis of trace elements in corals by laser ablation ICP-MS. Geochim. Cosmochim. Acta 62, 1889-1901. doi:10.1016/S0016-7037(98)00112-4

Sinclair, D.J., Williams, B., Allard, G., Ghaleb, B., Fallon, S., Ross, S.W., Risk, M., 2011. Reproducibility of trace element profiles in a specimen of the deep-water bamboo coral Keratoisis sp. Geochim. Cosmochim. Acta 75, 5101-5121. doi:10.1016/j.gca.2011.05.012 
Skliris, N., Sofianos, S., Gkanasos, A., Mantziafou, A., Vervatis, V., Axaopoulos, P., Lascaratos, A., 2012. Decadal scale variability of sea surface temperature in the Mediterranean Sea in relation to atmospheric variability. Ocean Dyn. 62, 13-30. doi:10.1007/s10236-011-0493-5

Taviani, M., 1997. L'uomo ed il corallo. Ori delle Alpi, Catalogo della Mostra, Quaderni della Sezione Archeologica del Castello del Buonconsiglio, Monumenti e Collezioni Provinciali Trento, pp. 151-152.

Taviani, M., Freiwald, A., Beuck, L., Angeletti, L., Remia, A., Vertino, A., Dimech, M., Schembri, P.J., 2010. The deepest known occurrence of the precious red coral Corallium rubrum (L. 1758) in the Mediterranean Sea. In: Bussoletti, E., Cottingham, D., Bruckner, A., Roberts, G., Sandulli, R. (eds) Proceedings of the International Workshop on Red Coral Science, Management, and Trade: Lessons from the Mediterranean. NOAA Technical Memorandum CRCP-13, pp. 87-93, Silver Spring, MD.

Tescione, G., 1973. The italians and their coral fishing. FaustoFiorentino, Napoli 490.

Thirumalai, K., Singh, A., Ramesh, R., 2011. A MATLABTM code to perform weighted linear regression with (correlated or uncorrelated) errors in bivariate data. Journal of the Geological Society of India 77 (4), 377-380.

Thresher, R.E., Fallon, S.J. and Townsend, A.T., 2016. A "core-top" screen for trace element proxies of environmental conditions and growth rates in the calcite skeletons of bamboo corals (Isididae). Geochim Cosmochim Acta 193, 75-99.

Thresher, R., Rintoul, S.R., Koslow, J.A., Weidman, C., Adkins, J., Proctor, C., 2004. Oceanic evidence of climate change in southern Australia over the last three centuries. Geophys. Res. Lett. 31, 2-5. doi:10.1029/2003GL018869

Thresher, R.E., MacRae, C.M., Wilson, N.C., Fallon, S., 2009. Feasibility of age determination of deep-water bamboo corals (Gorgonacea; Isididae) from annual cycles in skeletal composition. Deep-Sea. Res. Part I Oceanogr. Res. Pap. 56, 442-449. doi:10.1016/j.dsr.2008.10.003

Thresher, R.E., MacRae, C.M., Wilson, N.C., Gurney, R., 2007. Environmental effects on the skeletal composition of deep-water gorgonians (Keratoisis spp.; Isididae). Bull. Mar. Sci. 81, 409-422.

Thresher, R.E., Wilson, N.C., Macrae, C.M., Neil, H., 2010. Temperature effects on the calcite skeletal composition of deep-water gorgonians (Isididae). Geochim. Cosmochim. Acta 74, 4655-4670. doi:10.1016/j.gca.2010.05.024

Tisnérat-Laborde, N., Montagna, P., McCulloch, M.T., Siani, G., Silenzi, S., Frank, N., 2013. A high-resolution coral-based $\Delta^{14} \mathrm{C}$ record of surface water processes in the Western Mediterranean Sea. Radiocarbon 55, 1-14. doi:10.2458/azu

Trotter, J., Montagna, P., McCulloch, M., Silenzi, S., Reynaud, S., Mortimer, G., Martin, S., Ferrier-Pagès, C., Gattuso, J.-P., Rodolfo-Metalpa, R., 2011. Quantifying the $\mathrm{pH}$ "vital effect" in the temperate zooxanthellate coral Cladocora caespitosa: Validation of the boron seawater $\mathrm{pH}$ proxy. Earth Planet. Sci. Lett. 303, 163-173. doi:10.1016/j.epsl.2011.01.030

Tsounis, G., Rossi, S., Gili, J.M., Arntz, W.E., 2007. Red coral fishery at the Costa Brava (NW Mediterranean): Case study of an overharvested precious coral. Ecosystems 10, 975-986. doi:10.1007/s10021-007-9072-5

Tsounis, G., Rossi, S., Laudien, J., Bramanti, L., Fernández, N., Gili, J.M., Arntz, W., 2006. Diet and seasonal prey capture rates in the Mediterranean red coral (Corallium rubrum L.). Mar. Biol. 149, 313-325. doi:10.1007/s00227-005-0220-1 
Van Beek, P., Sternberg, E., Reyss, J.L., Souhaut, M., Robin, E., Jeandel, C. 2009. ${ }^{228} \mathrm{Ra} /{ }^{226} \mathrm{Ra}$ and ${ }^{226} \mathrm{Ra} / \mathrm{Ba}$ ratios in the Western Mediterranean Sea: barite formation and transport in the water column. Geochimica et Cosmochimica Acta 73, 4720-4737; doi:10.1016/j.gca.2009.05.063.

Vargas-Yáñez, M., Jesús García, M.J., Salat, J., García-Martínez, M.C., Pascual, J., Moya, F., 2008. Warming trends and decadal variability in the Western Mediterranean shelf. Glob. Planet. Change 63, 177-184. doi:10.1016/j.gloplacha.2007.09.001

Velimirov, B., Böhm, E.L., 1976. Calcium and magnesium carbonate concentrations in different growth regions of gorgonians. Mar. Biol. 35, 269-275. doi:10.1007/BF00396874

Vertino, A., Zibrowius, H., Taviani, M., Rocca, M. (2010) Fossil Coralliidae in the Mediterranean basin. In: Bussoletti, E., Cottingham, D., Bruckner, A., Roberts, G., Sandulli, R. (eds) Proceedings of the International Workshop on Red Coral Science, Management, and Trade: Lessons from the Mediterranean. NOAA Technical Memorandum CRCP-13, pp. 94-98, Silver Spring, MD.

Vertino, A., Stolarski, J., Bosellini, F., Taviani, M., 2014. Mediterranean corals through time: from Miocene to Present. In: Goffredo, S., Dubinsky, Z. (eds.) The Mediterranean Sea: Its history and present challenges, 257-274, Springer Science+Business Media Dordrecht. doi:10.1007/978-94-007-6704-1

Vielzeuf, D., Floquet, N., Chatain, D., Bonneté, F., Ferry, D., Garrabou, J., Stolper, E.M., 2010. Multilevel modular mesocrystalline organization in red coral. Am. Mineral. 95, 242-248. doi:10.2138/am.2010.3268

Vielzeuf, D., Gagnon, A.C., Ricolleau, A., Devidal, J., Balme-Heuze, C., Yahiaoui, N., Fonquernie, C., Perrin, J., Garrabou, J., Montel, J., Floquet, N., 2018. Growth kinetics and distribution of trace elements in precious corals. Front. Earth Sci. 6, 1-18. doi:10.3389/feart.2018.00167

Vielzeuf, D., Garrabou, J., Baronnet, A., Grauby, O., Marschal, C., 2008. Nano- to macroscale biomineral architecture of red coral (Corallium rubrum). Am. Mineral. 93, 1799-1815. doi:10.2138/am.2008.2923

Vielzeuf, D., Garrabou, J., Gagnon, A., Ricolleau, A., Adkins, J., Günther, D., Hametner, K., Devidal, J.L., Reusser, E., Perrin, J., Floquet, N., 2013. Distribution of sulphur and magnesium in the red coral. Chem. Geol. 355, 13-27. doi:10.1016/j.chemgeo.2013.07.008

Weinbauer, M.G., Brandstätter, F., Velimirov, B., 2000. On the potential use of magnesium and strontium concentrations as ecological indicators in the calcite skeleton of the red coral (Corallium rubrum). Mar. Biol. 137, 801-809.

Weinbauer, M.G., Velimirov, B., 1995. Calcium, magnesium and strontium concentrations in the calcite sclerites of Mediterranean gorgonians (Coelenterata: Octocorallia). Estuar. Coast. Shelf Sci. 40, 87-104. doi:10.1016/0272-7714(95)90015-2

Yoshimura, T., Tanimizu, M., Inoue, M., Suzuki, A., Iwasaki, N., Kawahata, H., 2011. Mg isotope fractionation in biogenic carbonates of deep-sea coral, benthic foraminifera, and hermatypic coral. Anal. Bioanal. Chem. 401, 2755-2769. doi:10.1007/s00216-011-52640 .

\section{Figure Captions}


Figure 1. (A) Map of C. rubrum sampling locations in the Western Mediterranean and the Siculo-Tunisian Strait with depth and annual mean temperatures for each site. Three colonies have been retrieved from shallow water between 15 and $21 \mathrm{~m}$ depth at Riou Island (RI) and Corsica (CO) in France, and at Medes Islands (MI) in Spain. The sample from Portofino (PF) in Italy stems from $50 \mathrm{~m}$ depth. The deepest sample is from $607 \mathrm{~m}$ depth in the SiculoTunisian Strait (MS-43). (B) Mean annual temperatures per site plotted with mean annual minima and maxima temperatures; note the similarity of minima at all sites. (C) Mean annual temperatures plotted against annual temperature amplitude. Near stable conditions with $\sim 0.2^{\circ} \mathrm{C}$ annual amplitude occur at $-607 \mathrm{~m}$ depth and low amplitudes $\left(\sim 4^{\circ} \mathrm{C}\right)$ are observed for the Portofino sample at $-50 \mathrm{~m}$ depth. Shallower sites $(-21$ to $-15 \mathrm{~m})$ have higher annual amplitudes between $\sim 8$ and $\sim 10^{\circ} \mathrm{C}$.

Figure 2. Thin-section images of the $C$. rubrum specimens MI, RI, PF and MS-43. (A, D, G and J) Images obtained under plane-polarized light microscope; (B, E, H and K) Scanning electron microscope images in back-scattered electron mode and (C, F, I and L) images obtained after etching and organic matrix Toluidine blue staining under plane-polarized light microscope.

Figure 3. Laser ablation tracks for elemental analysis across the stems of the C. rubrum colonies: (A) sample RI from Riou Island, (B) sample CO from Corsica, (C) sample MI from Medes Islands, and (D) sample MS-43 from SW Malta. Tracks are oriented perpendicular to the growth direction and arrows indicate laser moving direction.

Figure 4. Scanning electron microscope images of C. rubrum, comparing the internal skeletal microstructures of broken branches of the deep-water specimen MS-43 (A to D) and shallowwater specimen MI (E to H). (A \& E) Sub-micrometer scale units, (B \& F) sclerites, (C-D \& G-H) crystalline fibers and blades.

Figure 5. Annual growth band counting in radial transects across the Toluidine blue stained thin-sections of the shallow-water specimen RI (A), and the deep-water sample MS-43 (B), with the medullar zone (beige envelope), intermediate zone (purple envelope) highlighted. Each annual band consists of a dark and a light band, corresponding to summer and winter months. Annual light and dark growth band thicknesses of the samples RI (C), MS-43 (D), MI (E) and PF (F). Mean annual band thickness plotted against mean ambient temperature (G). 
Mean light and dark band widths plotted against mean summer and winter temperatures $(\mathrm{H})$. Arrows (A to F) indicate radial growth direction.

Figure 6. $\mathrm{Mg} / \mathrm{Ca}(\mathrm{A}-\mathrm{D}), \mathrm{Sr} / \mathrm{Ca}(\mathrm{E}-\mathrm{H}), \mathrm{Li} / \mathrm{Ca}(\mathrm{I}-\mathrm{L}), \mathrm{B} / \mathrm{Ca}(\mathrm{M}-\mathrm{P})$ and $\mathrm{Ba} / \mathrm{Ca}(\mathrm{Q}-\mathrm{U})$ LA-ICP-MS profiles vs. linear distance for the samples RI, CO, MI and MS-43. Arrows indicate radial growth direction, with the middle portion representing the medullar zone; see Fig. 3 for the position of the laser tracks.

Figure 7. $\mathrm{Li} / \mathrm{Ca}, \mathrm{B} / \mathrm{Ca}, \mathrm{Mg} / \mathrm{Ca}, \mathrm{Sr} / \mathrm{Ca}$ and $\mathrm{Ba} / \mathrm{Ca} \mathrm{LA}-\mathrm{ICP}-\mathrm{MS}$ profiles vs. linear distance for sample MI. Element/Ca values are plotted on the image of the Toluidine blue stained thinsection (yellow band: medullar zone). The annular zone is composed of 30 dark and light bands, corresponding to the years 1978 to 2008 AD. Dark winter bands are tied to elemental transects with lines (magenta), their width corresponds to band width. $\mathrm{Mg} / \mathrm{Ca}$ shows an ontogenetic decrease across the annular zone.

Figure 8. (A, C, E, G, I and $\mathrm{K}$ ) Fine-scale variations in $\mathrm{Mg} / \mathrm{Ca}$ ratios along two parallel laser ablation transects in the samples $\mathrm{CO}$, MI and RI, plotted against the monthly seawater temperature records from 2003-2004 to 2008 obtained from the T-MedNet project (www.tmednet.org) close to the coral sampling locations. Each $\mathrm{Mg} / \mathrm{Ca}$ data point represents an 11point running mean. Tracks 1 and 2 correspond to transects 2, 4, 6 and 1, 3, 5 respectively in Fig. 3. The dashed lines, and the red and blue arrows represent the mean, maximum and minimum seawater temperatures for the sampling sites obtained from the NOAA NODC WOA13 $\left(0.25^{\circ}\right.$ grid $)$ database. Side 1 and 2 correspond to the first and last part of the laser ablation transect (i.e. the edge portions of the cross section) and span the last 4-5 years (from 2003-2004 to 2008). (B, D, F, H, J and L) Thickness of the light and dark bands of the samples CO, MI and RI. The total height of the bars corresponds to the thickness of the annual increment (light + dark band).

Figure 9. (A) $\mathrm{Mg} / \mathrm{Ca}$ vs. seawater temperature linear regressions for C. rubrum: Monthly and summer/winter $\mathrm{Mg} / \mathrm{Ca}$ values of the skeletal calcite vs. the corresponding the temperature data from T-MedNet and minimum, maximum, and mean $\mathrm{Mg} / \mathrm{Ca}$ values vs. with the coldest, warmest, and mean annual temperatures at the sampling locations from the NOAA WOA13 database. (B) $\mathrm{Mg} / \mathrm{Ca}$ vs. ambient seawater temperature calibration lines for calcific corals calculated by combining the data from this study (from the full data set) with the data published by Vielzeuf et al. (2013) and Yoshimura et al. (2011) (Blue envelope: 95\% 
confidence interval for the regression line 3; Red envelope: $95 \%$ confidence interval for the regression line 4).

Figure 10. (A) High resolution temperature records acquired from the T-MedNet plotted versus the reconstructed temperatures derived from the $\mathrm{Mg} / \mathrm{Ca}$ ratio in the 5 latest annual bands in C. rubrum from CO (A, B), MI (C, D) and RI (E, F) and compared to the maximum and the minimum annual temperature obtained from the NOAA NODC WOA13 $\left(0.25^{\circ}\right.$ grid $)$ database (Blue arrow: min temperature; red arrow: max temperature). Note the different results of reconstructed temperatures from Equations 2 and 4, as well as differences between coral sides.

Figure 11. Reconstructed temperature derived from $\mathrm{Mg} / \mathrm{Ca}$ across the last 30 growth bands of the coral section collected from the shallow-water of Medes Island matched to the highresolution measured temperature from the same location (Calvo et al., 2011; Salat and Pascual, 2002; T-MedNet network).

Figure 12. (A) $\mathrm{Mg} / \mathrm{Ca}$ ratios variations along LA-ICP-MS transect in the recent C. rubrum from MS-43, plotted together with the temperature records from the T-MedNet for the latest 5 years from 2003 to 2008 AD. Minimum and maximum annual temperatures (Blue and red arrows, respectively) obtained from the NOAA NODC WOA13 (0.25 $5^{\circ}$ grid $)$ database. (B) Growth (light and dark) band thicknesses. (C and D) Reconstructed interannual temperature variabilities from $\mathrm{Mg} / \mathrm{Ca}$ overestimate near stable deep-water temperature variability, while mean reconstructed temperatures coincide with measured mean temperatures (Equation 2 envelopes correspond to $95 \%$ confidence intervals). 

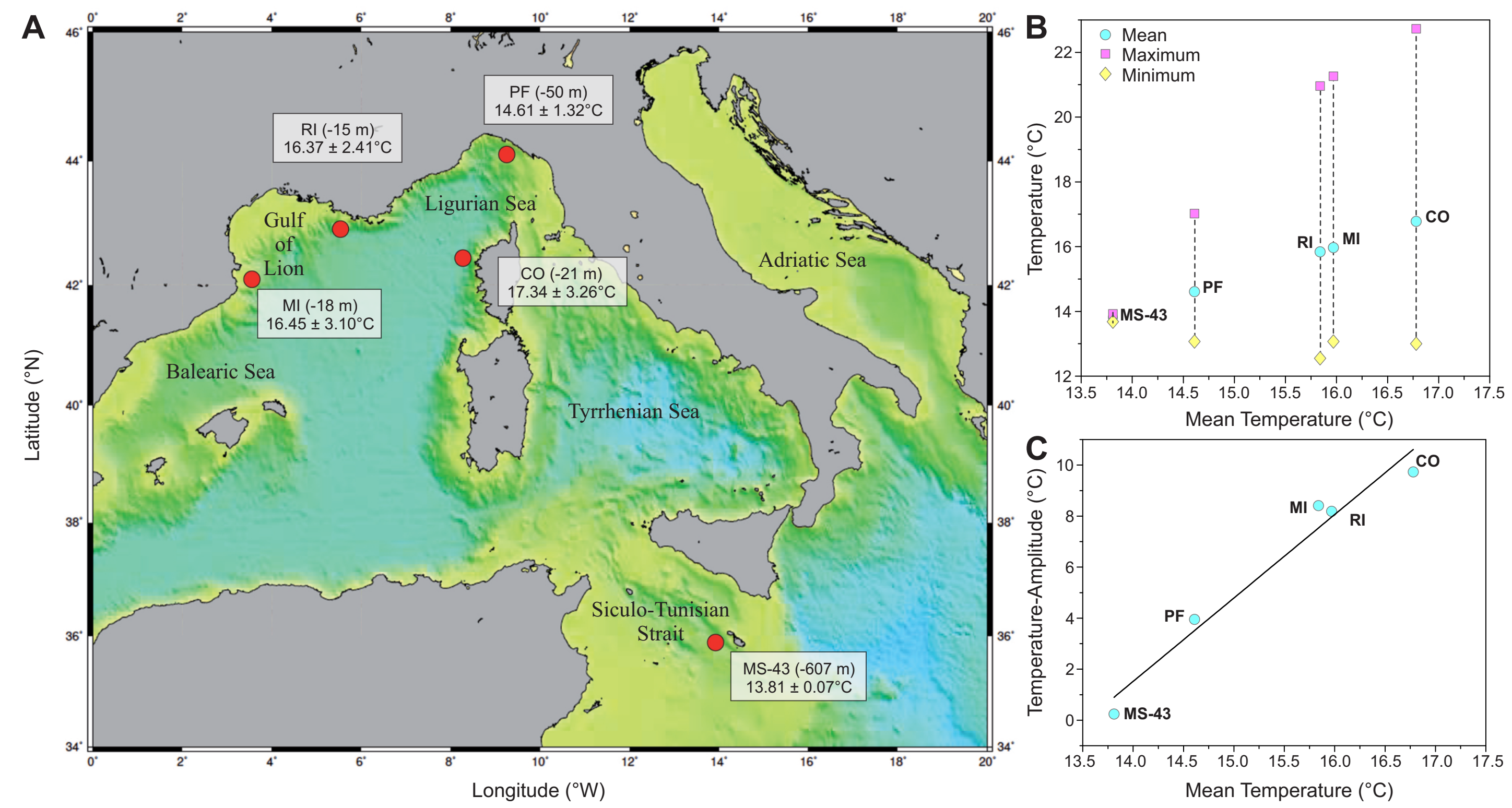

Fig. 1 
MI

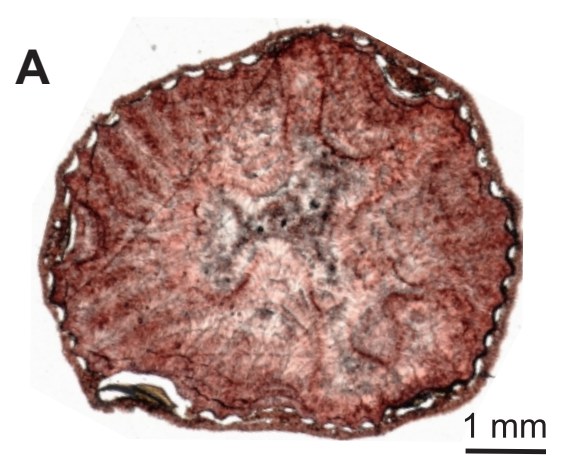

B

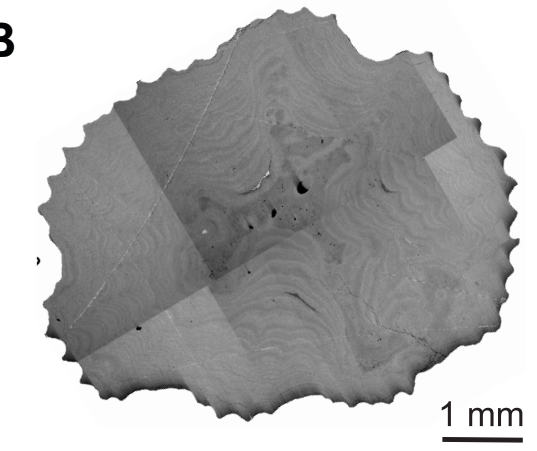

C

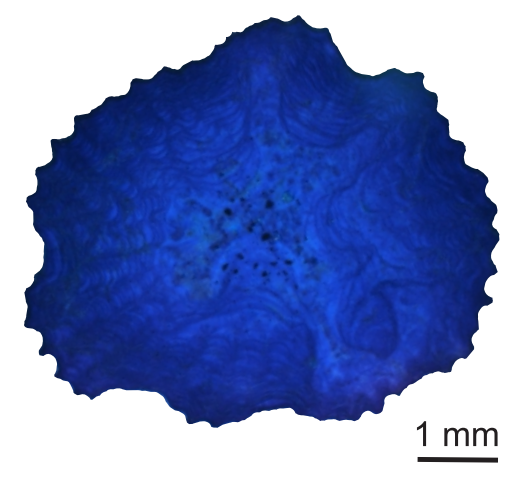

RI

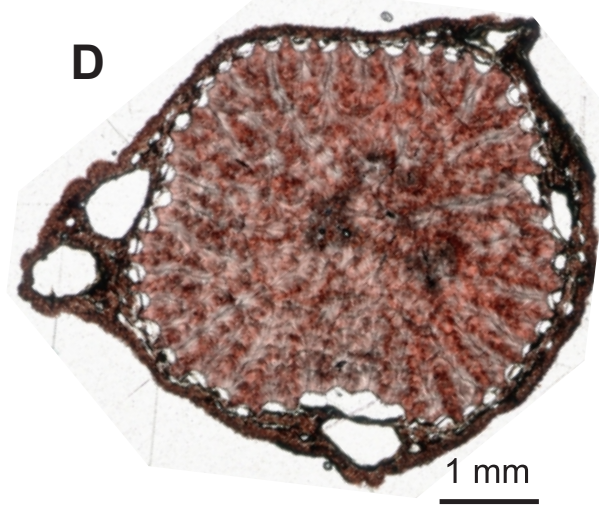

E
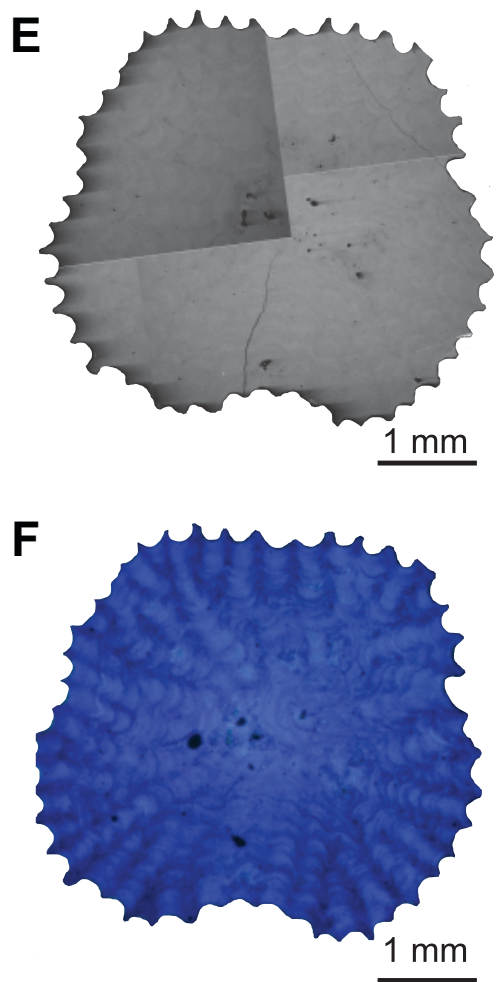

PF

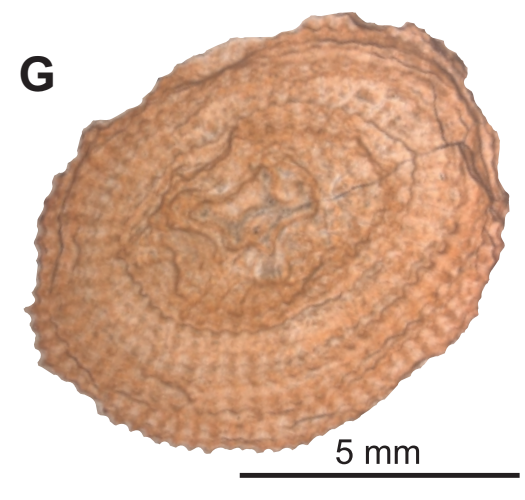

H
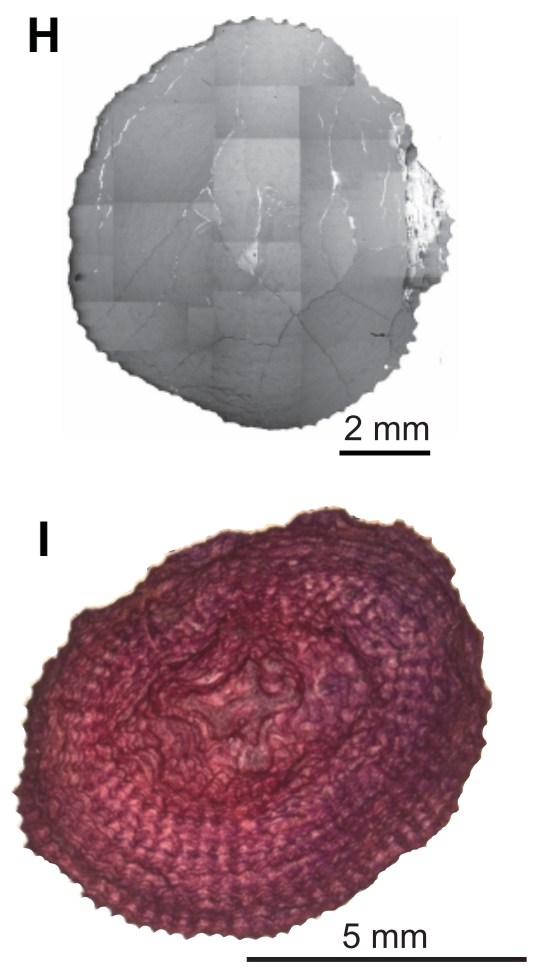

MS-43

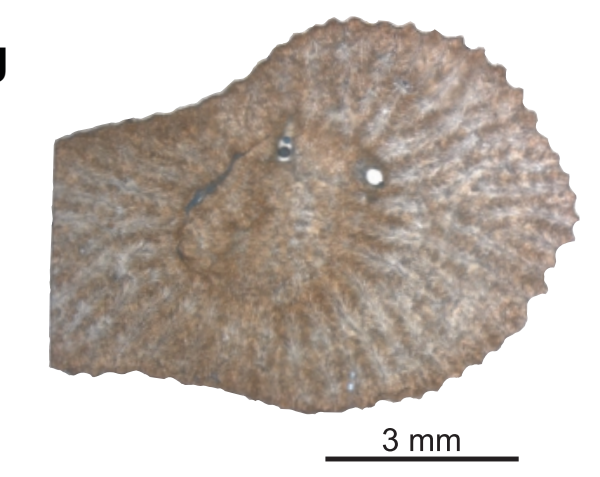

K

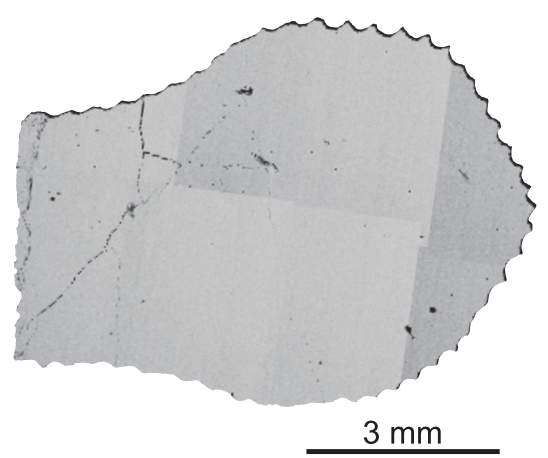

L

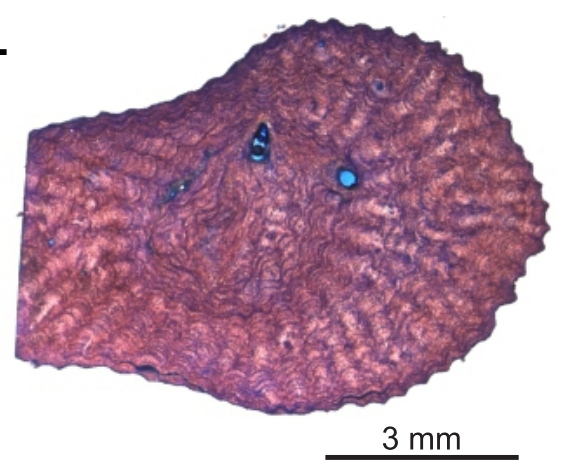

Fig. 2 

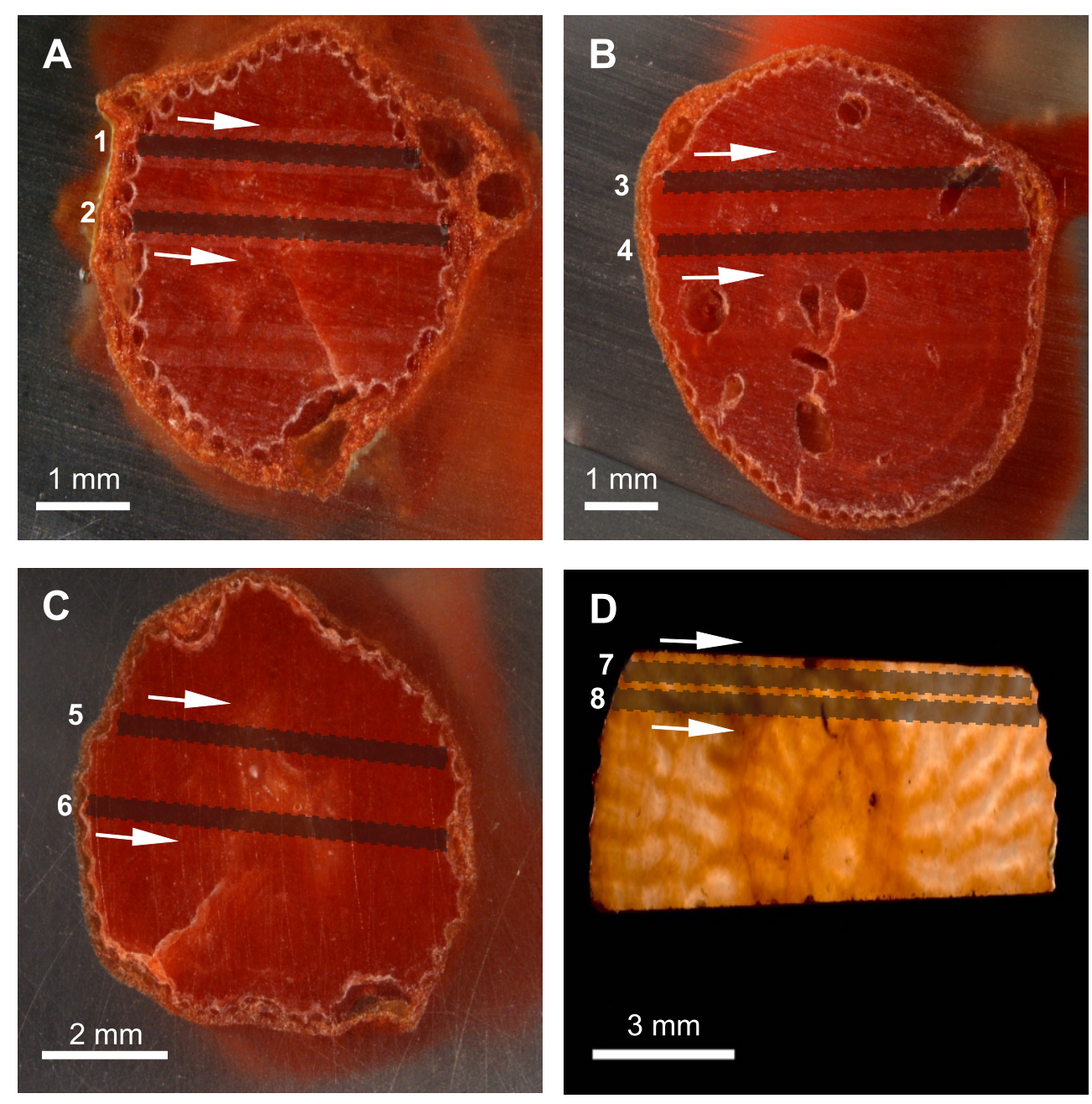

Fig. 3 

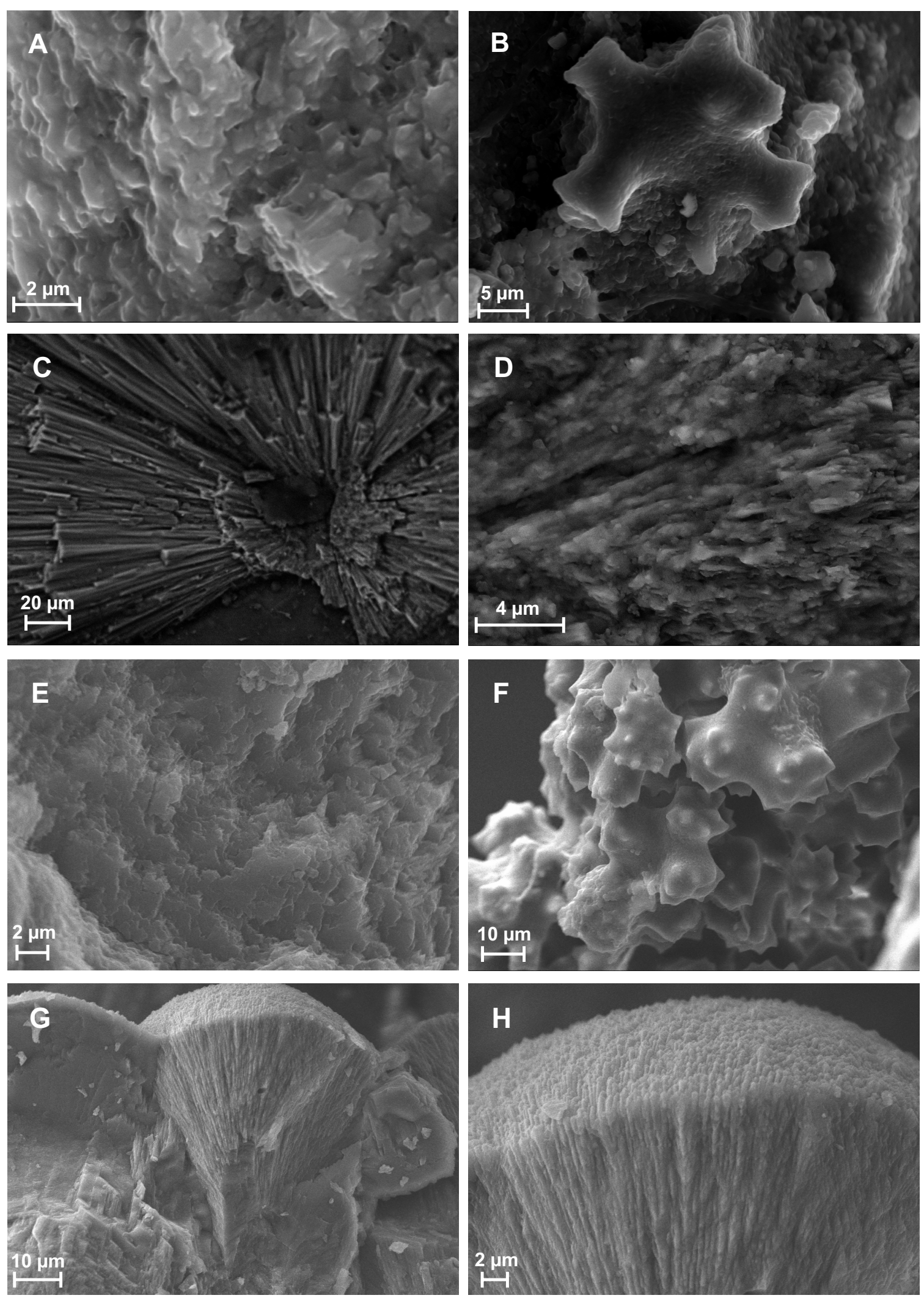

Fig. 4 

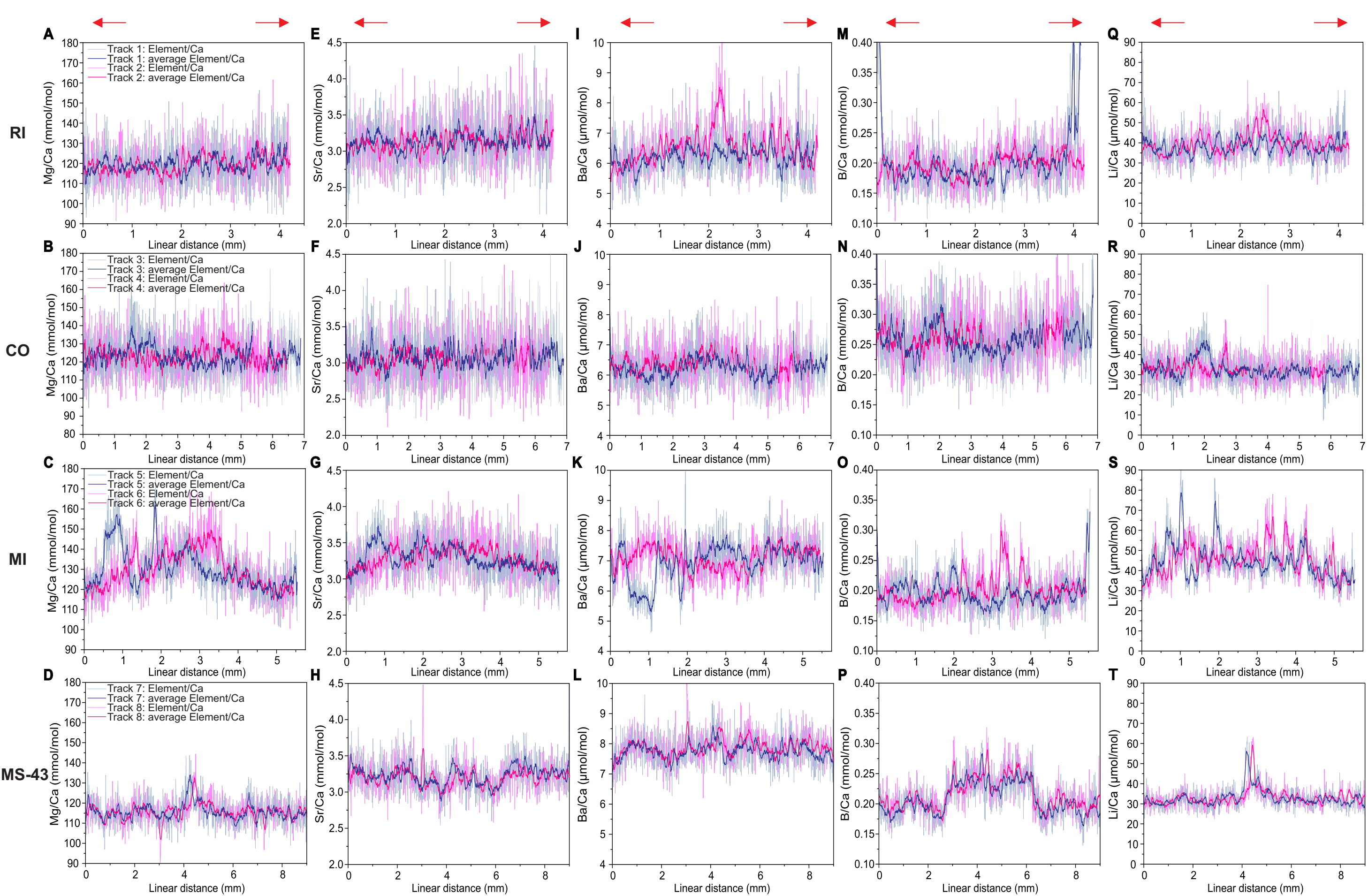

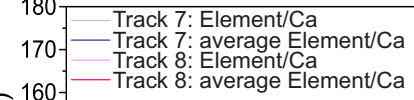

है $150-$

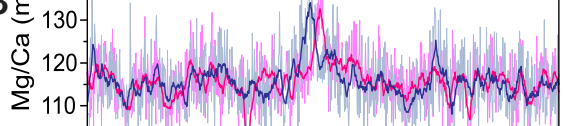

$100-$
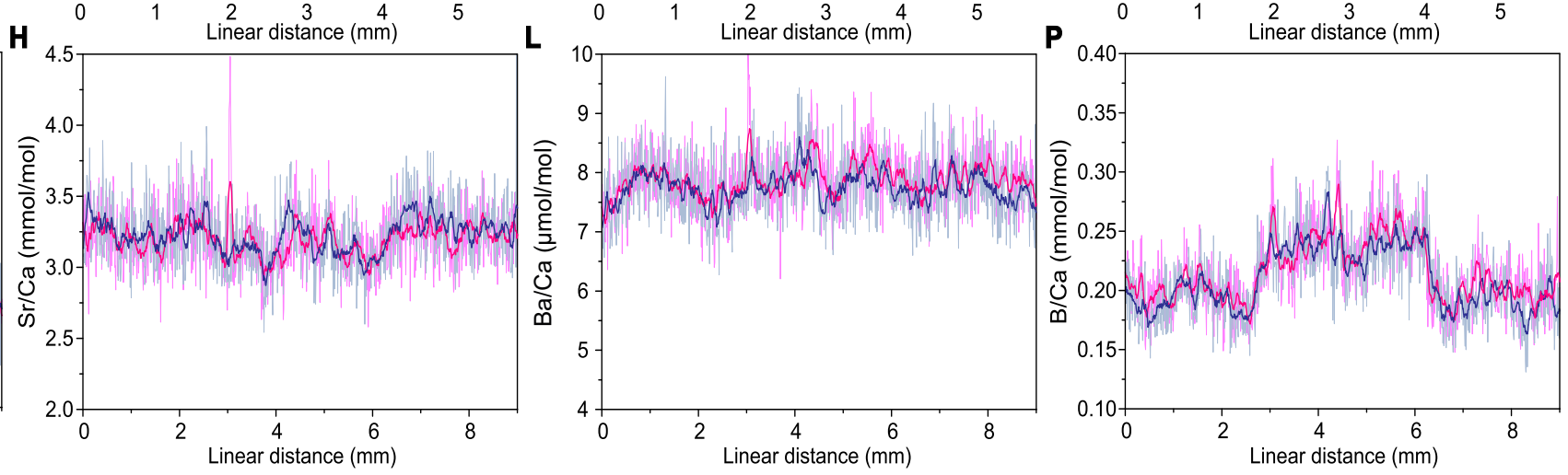

Fig. 6 

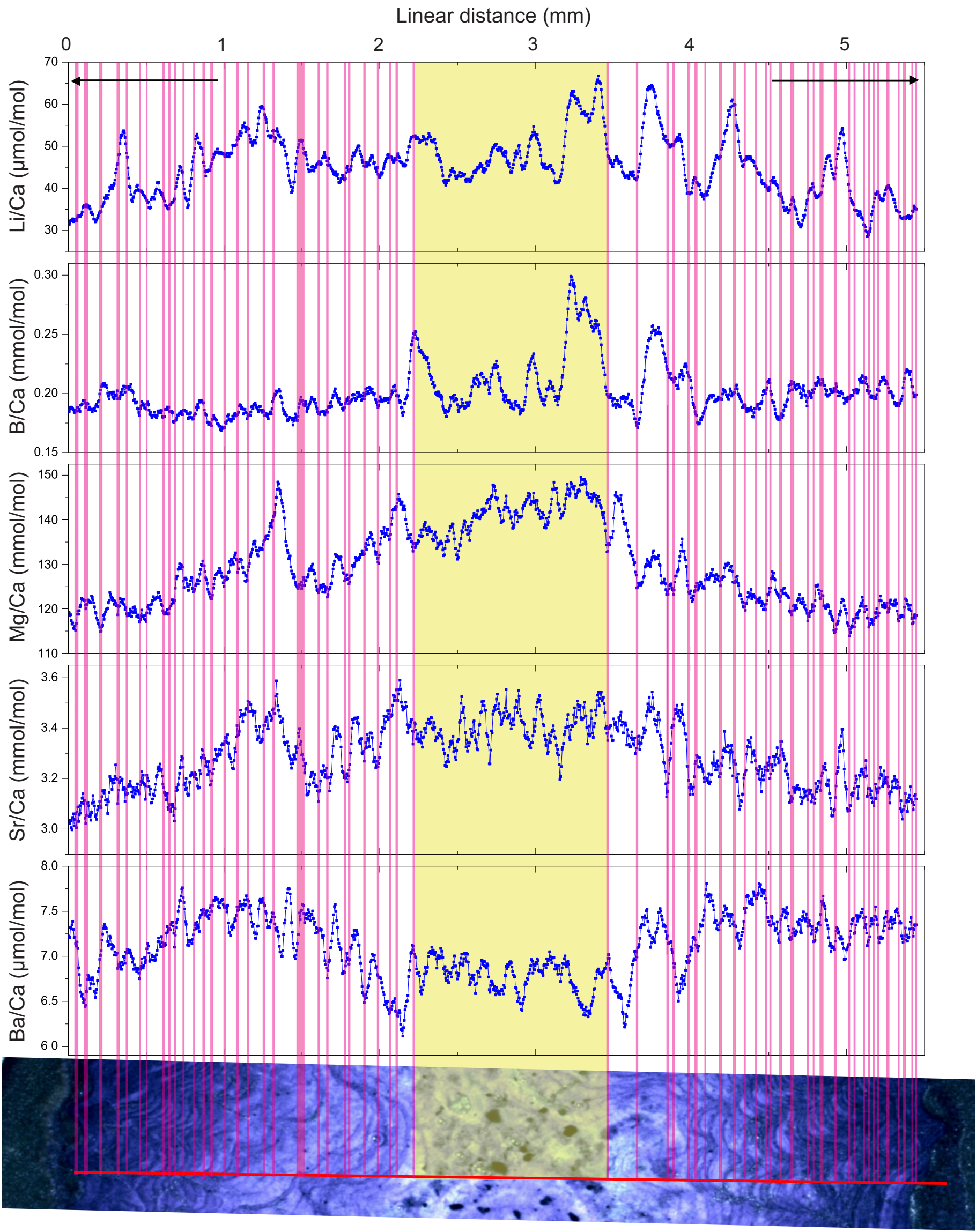

Fig. 7 
Track 1
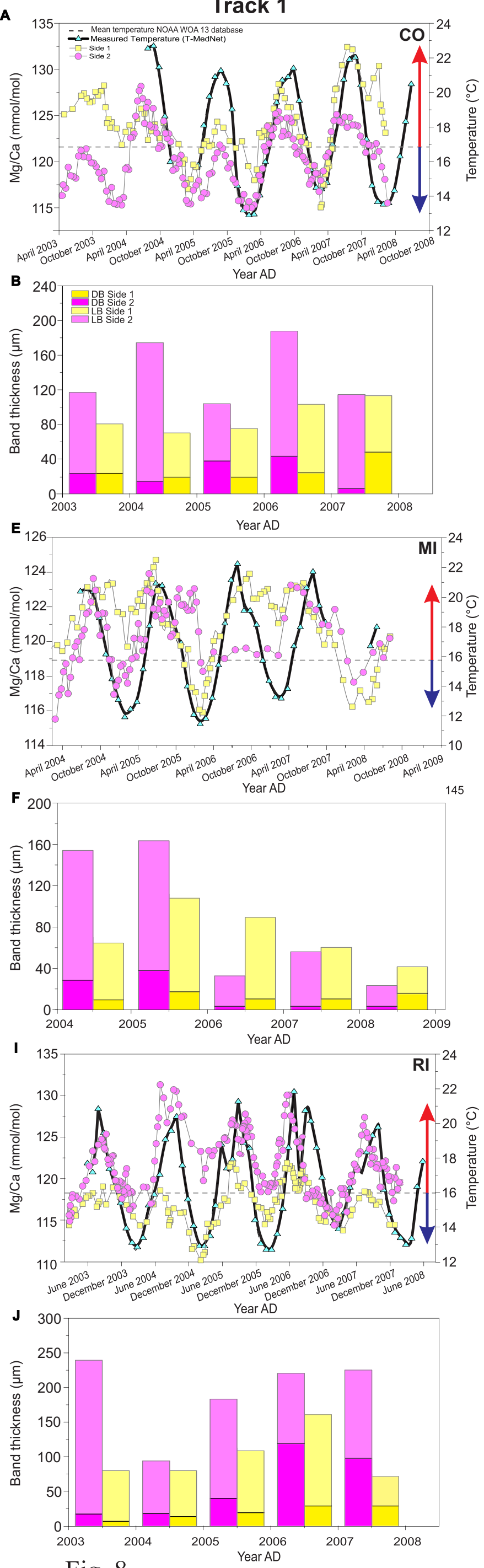

Fig. 8

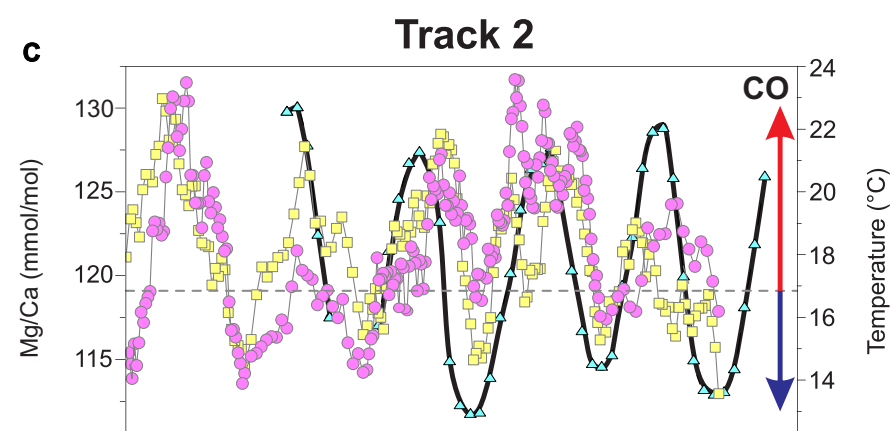

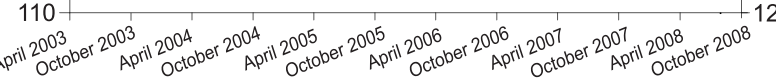
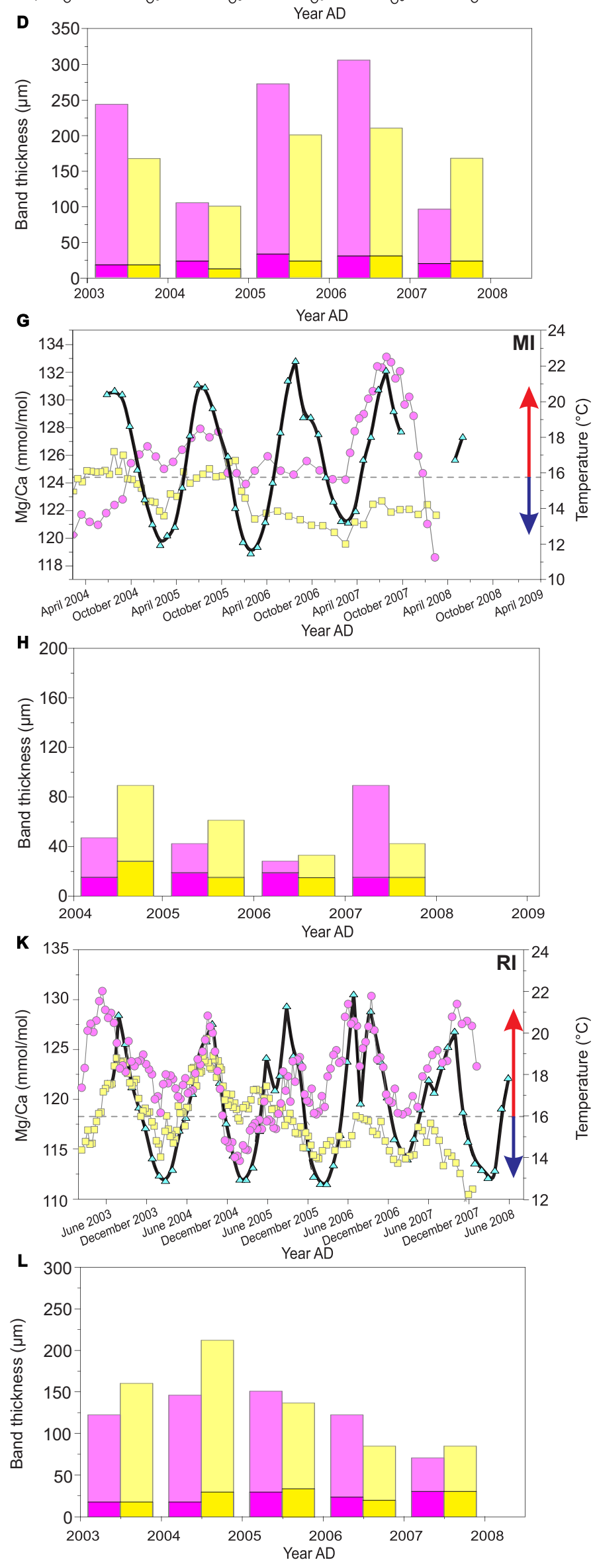
A

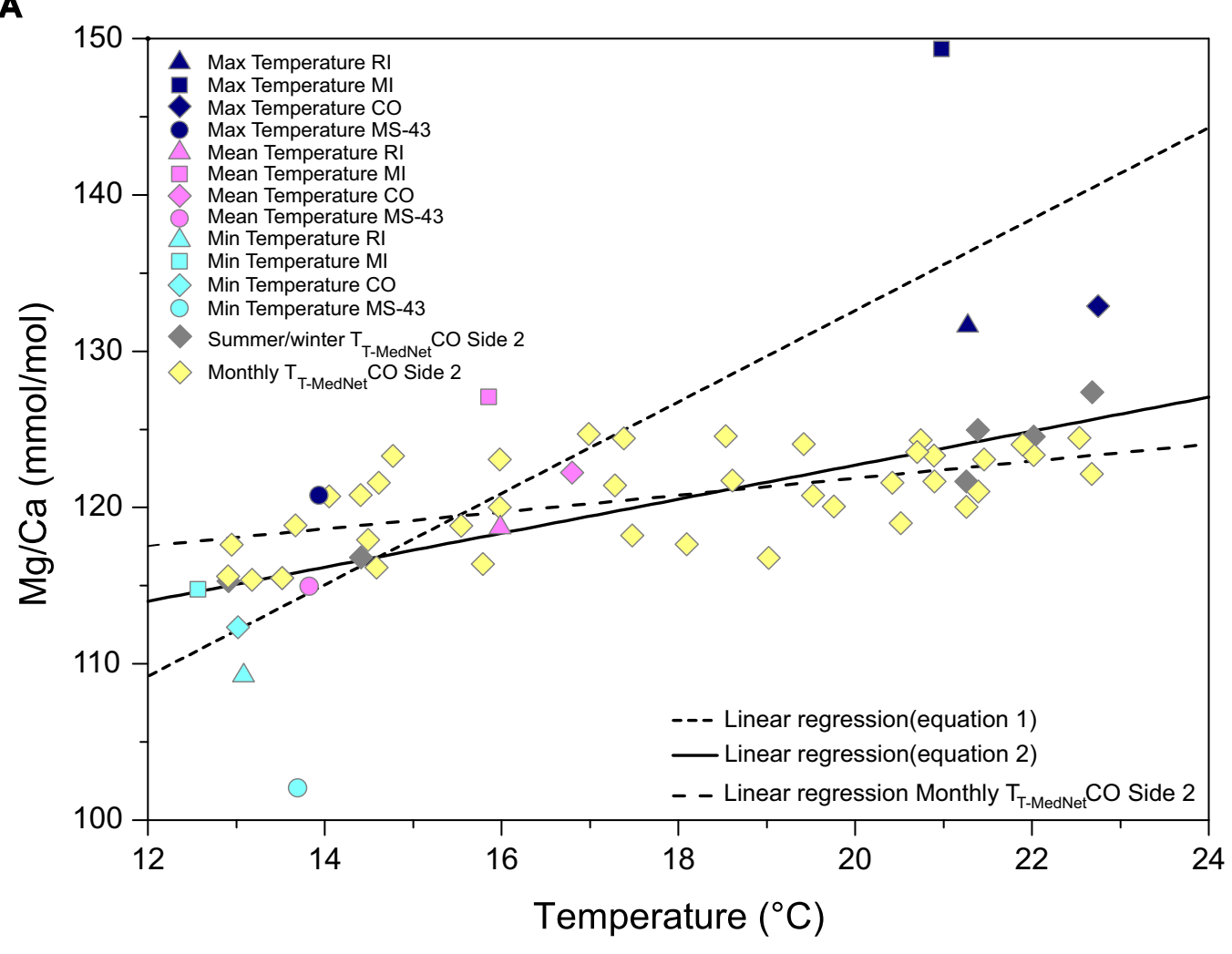

B

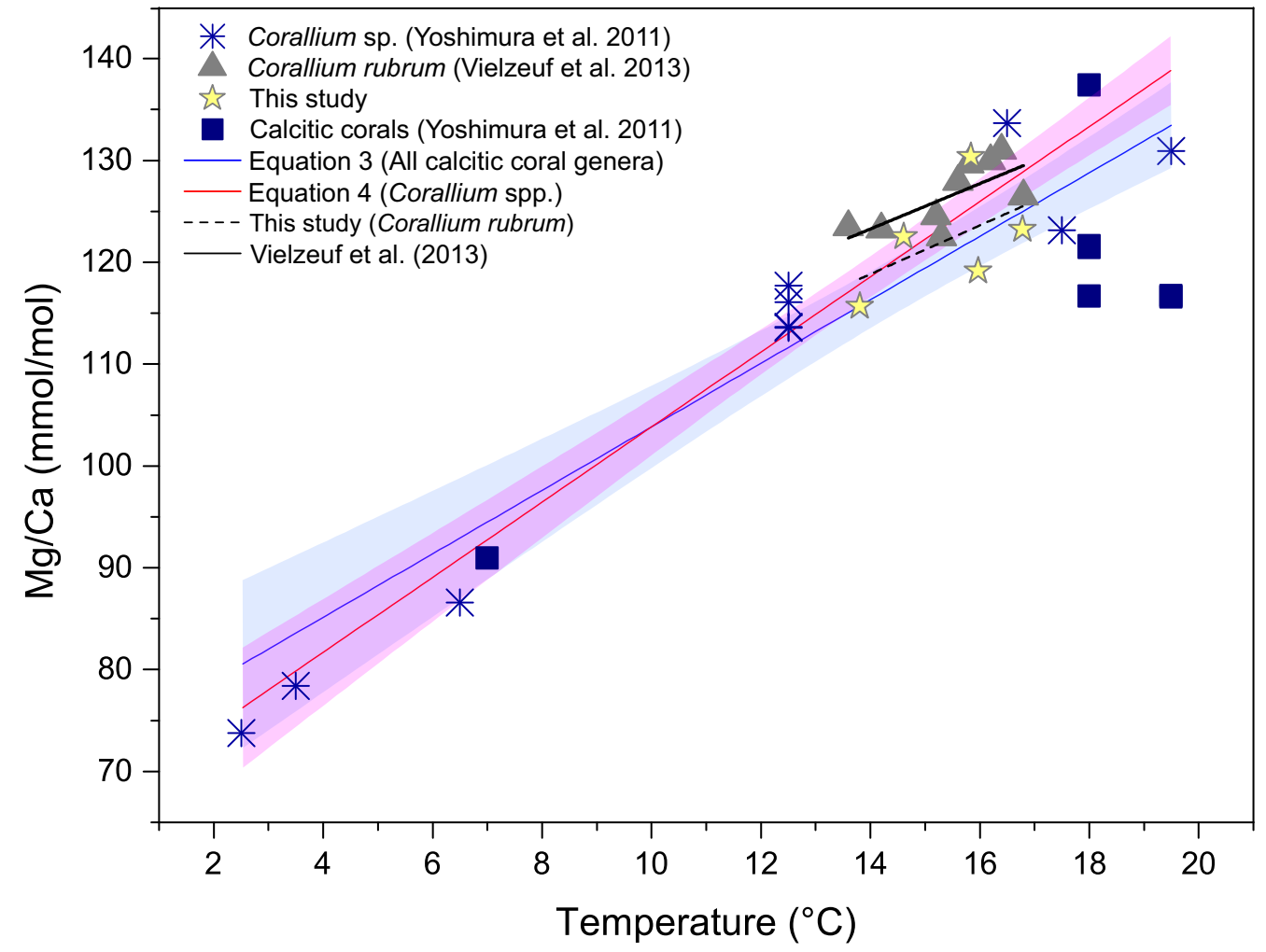

Fig. 9 


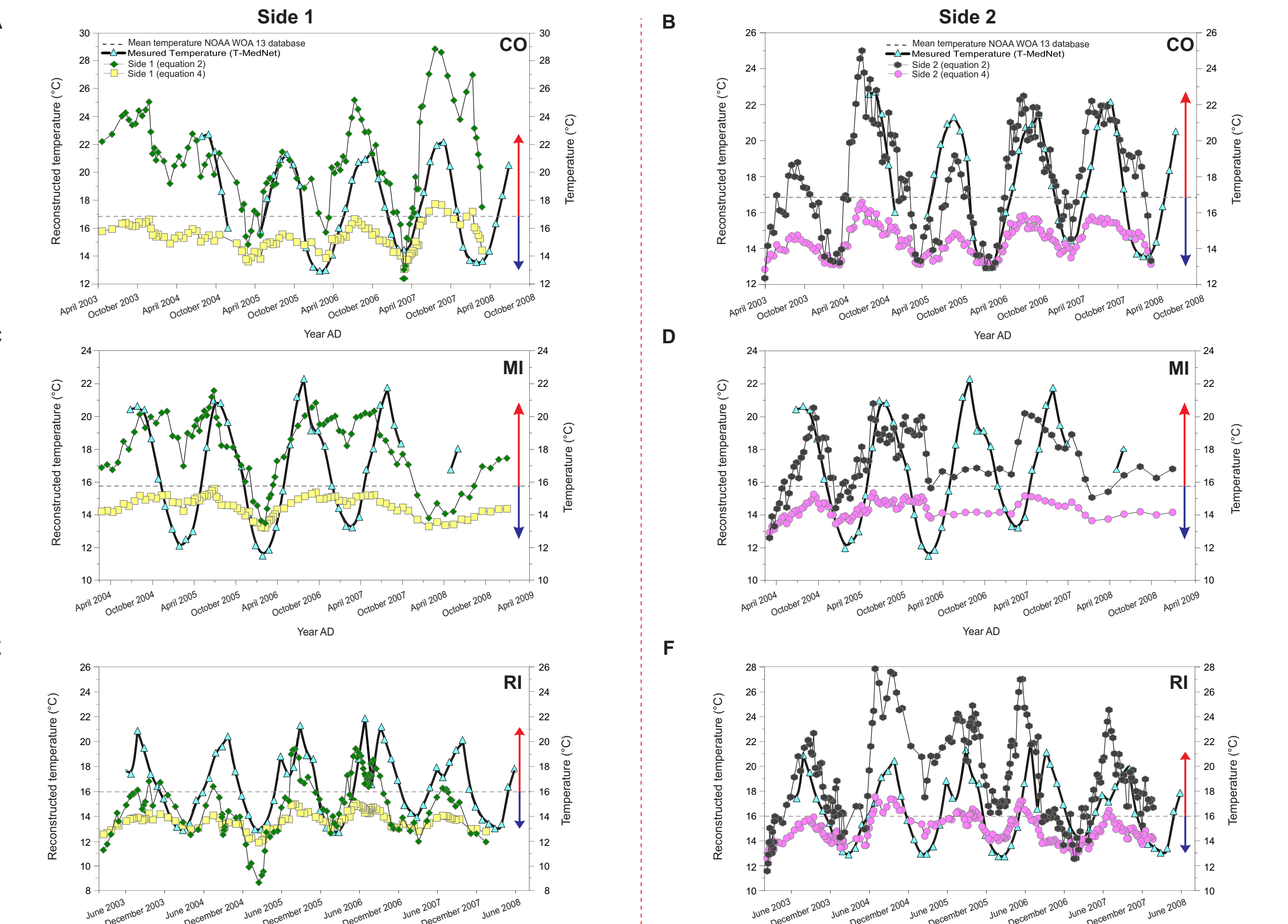




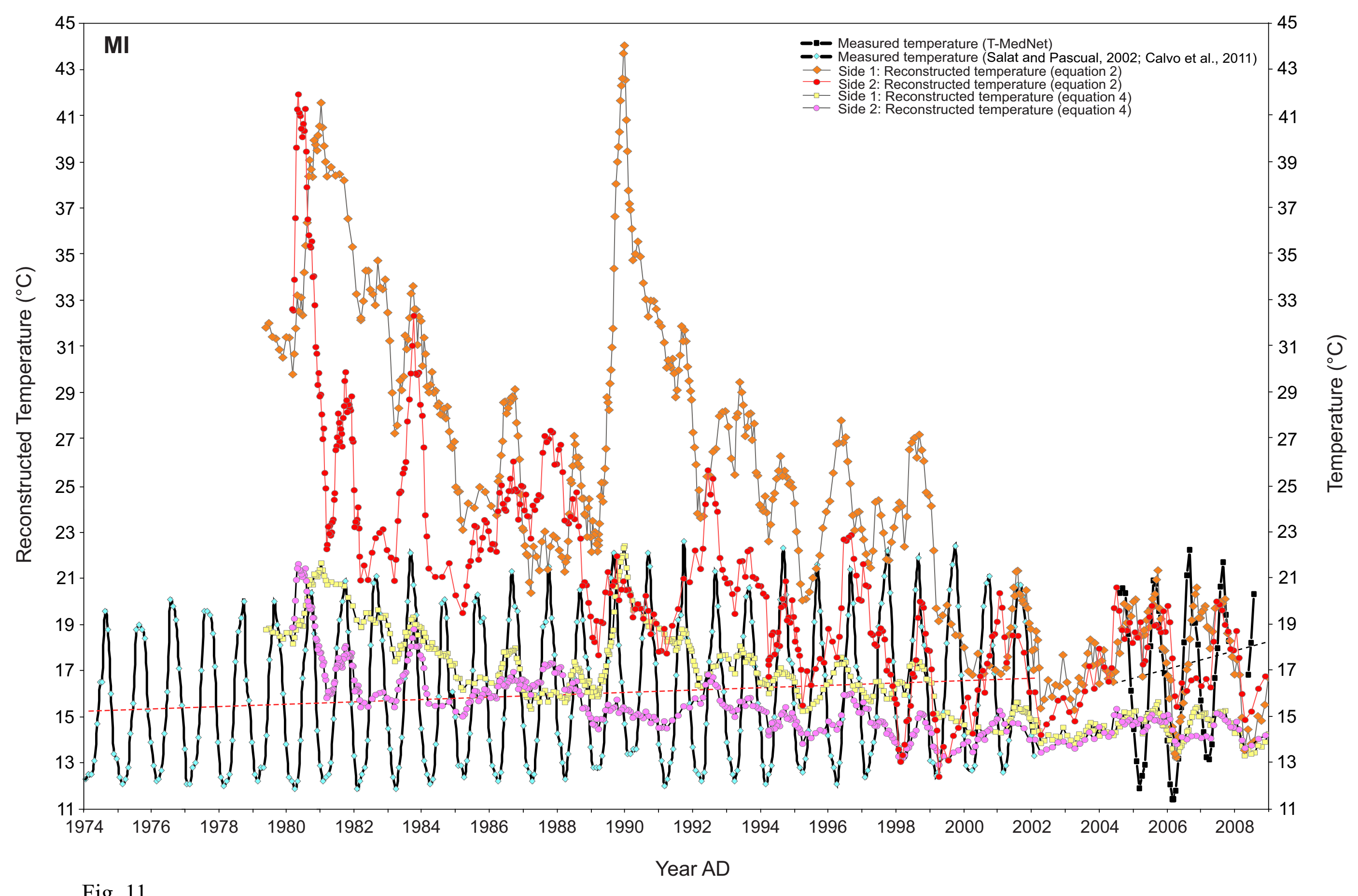

Fig. 11 
A

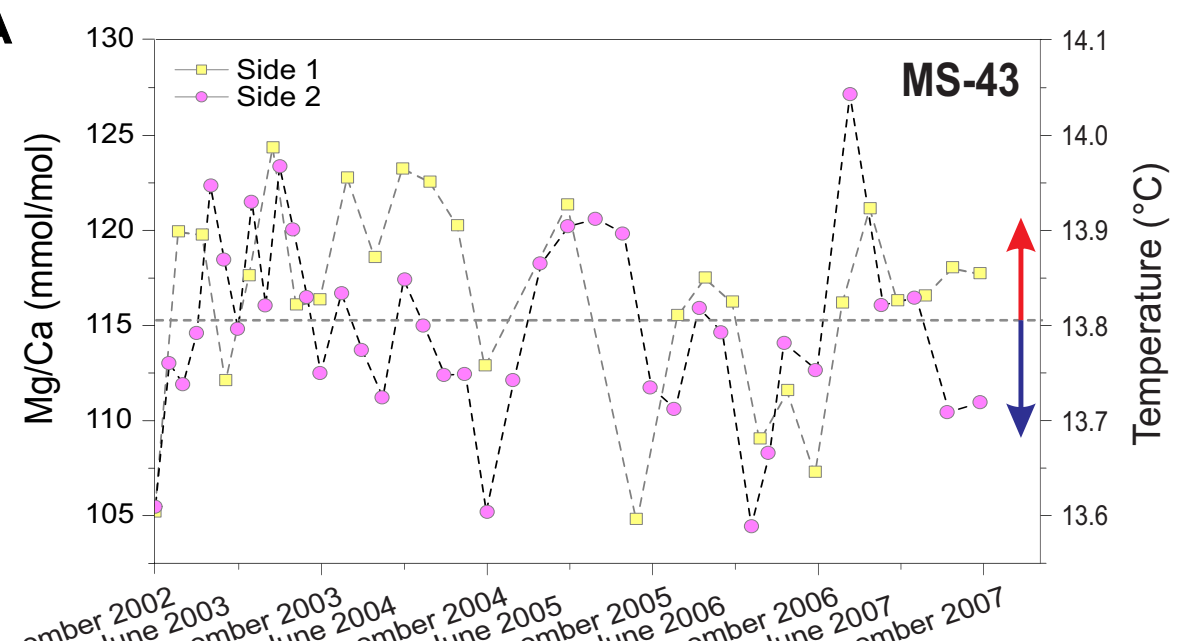

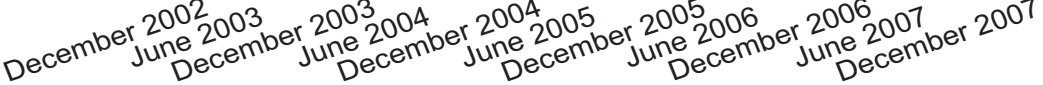

B Year AD

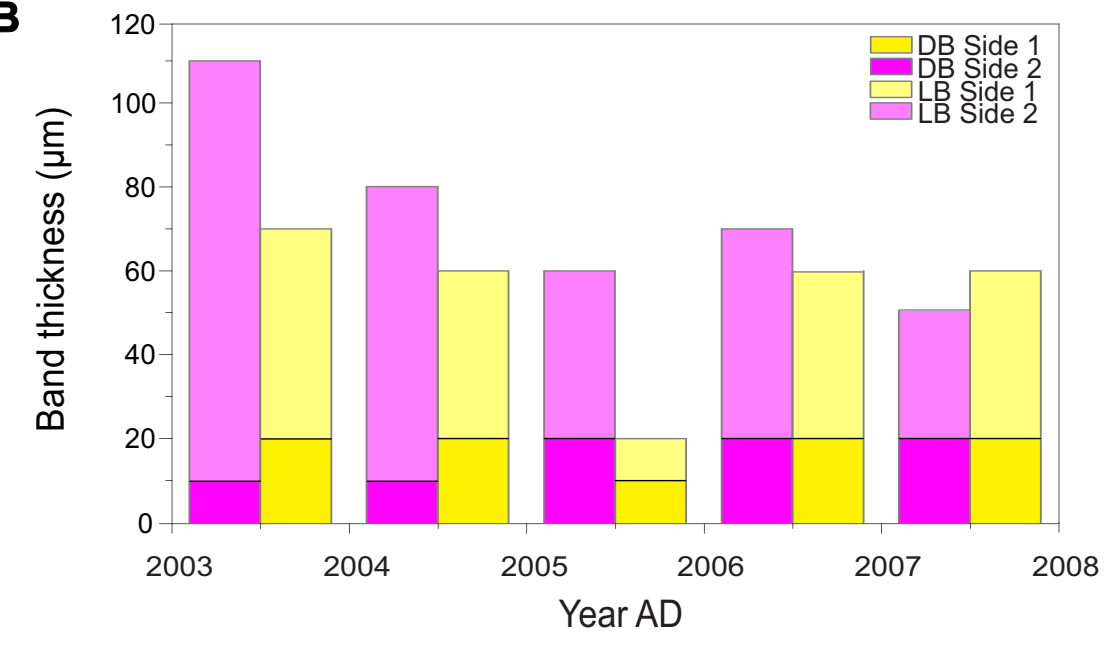

Fig. 12
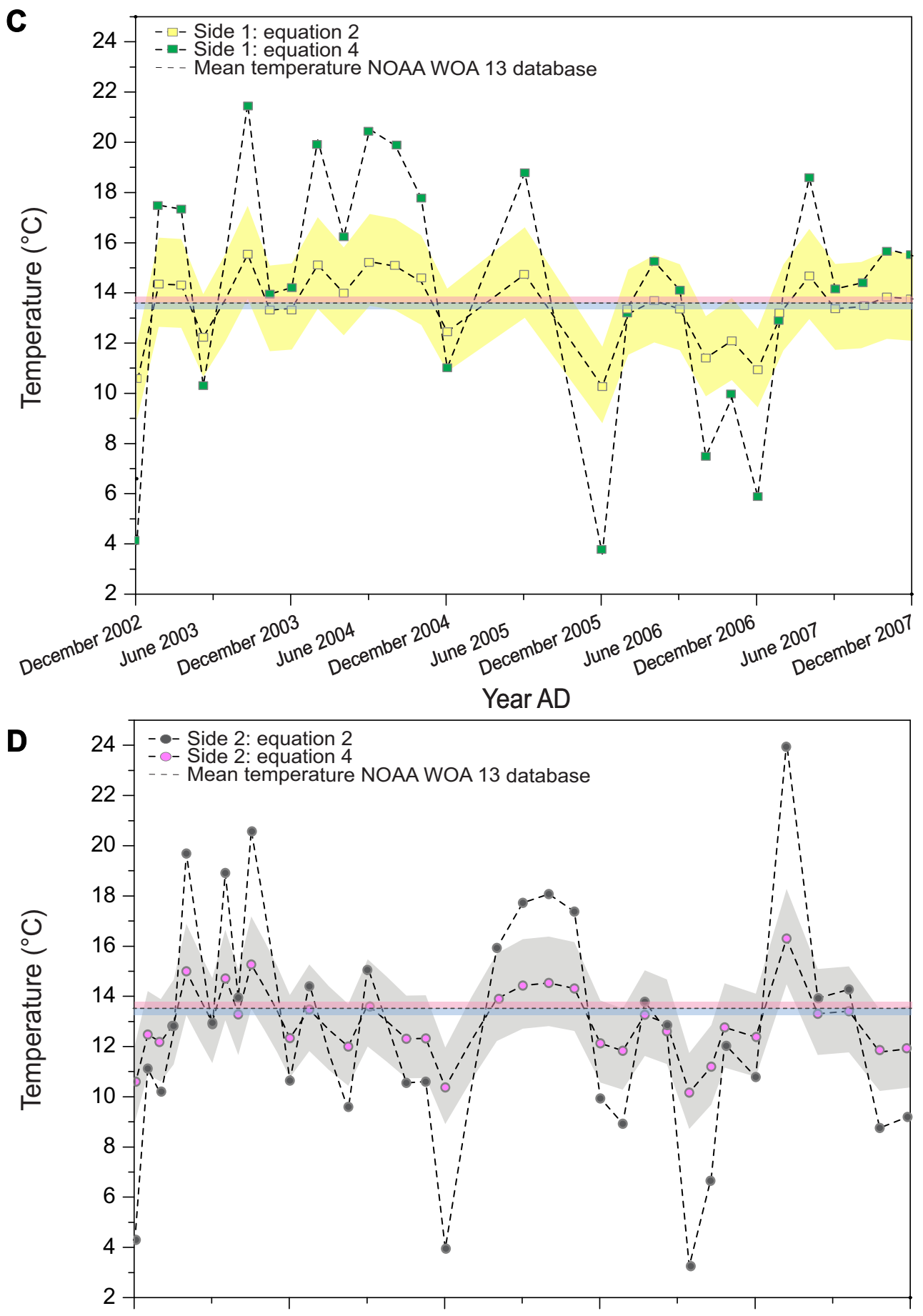

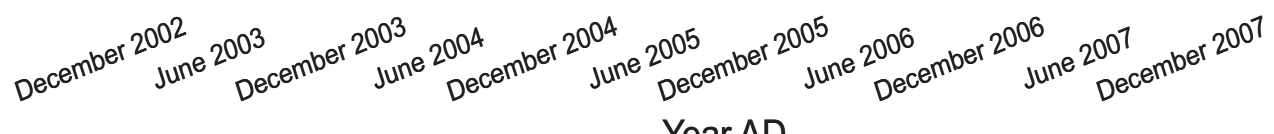


Table 1. Sampling locations of C. rubrum live-collected from the Mediterranean Sea

\begin{tabular}{|c|c|c|c|c|c|c|c|c|}
\hline Sample code & Location & Depth (m) & Latitude & Longitude & Mean $\mathbf{T}\left({ }^{\circ} \mathrm{C}\right)$ & $\operatorname{Max} T\left({ }^{\circ} \mathrm{C}\right)$ & $\operatorname{Min} \mathbf{T}\left({ }^{\circ} \mathbf{C}\right)$ & Collection date \\
\hline $\mathbf{R I}$ & Riou Island, France & $\begin{array}{c}15^{\mathrm{e}} \\
15^{\mathrm{e}}\end{array}$ & $\begin{array}{c}43^{\circ} 11 \mathrm{~N}^{\prime} \\
43^{\circ} 17^{\prime} \mathrm{N}^{\mathrm{c}}\end{array}$ & $\begin{array}{c}05^{\circ} 23^{\prime} \mathrm{E} \\
05^{\circ} 38^{\prime} \mathrm{E}^{\mathrm{c}}\end{array}$ & $\begin{array}{l}16.37 \pm 2.41^{\mathbf{a}} \\
15.97 \pm 2.57^{\mathbf{b}}\end{array}$ & $\begin{array}{l}19.91 \pm 2.74^{\mathrm{a}} \\
21.26 \pm 022^{\mathrm{b}}\end{array}$ & $\begin{array}{l}13.21 \pm 0.22^{\mathrm{a}} \\
13.07 \pm 0.04^{\mathrm{b}}\end{array}$ & June 2008 \\
\hline MI & $\begin{array}{l}\text { Medes Islands, } \\
\text { Spain }\end{array}$ & $\begin{array}{c}18 \\
20^{\mathrm{e}}\end{array}$ & $\begin{array}{c}42^{\circ} 02^{\prime} \mathrm{N} \\
42^{\circ} 04^{\prime} \mathrm{N}^{\mathrm{c}}\end{array}$ & $\begin{array}{c}03^{\circ} 13^{\prime} \mathrm{E} \\
03^{\circ} 22^{\prime} \mathrm{E}^{\mathrm{c}}\end{array}$ & $\begin{array}{l}16.45 \pm 3.10^{\mathrm{a}} \\
15.84 \pm 3.05^{\mathrm{b}}\end{array}$ & $\begin{array}{l}21.00 \pm 2.00^{\mathrm{a}} \\
20.96 \pm 0.34^{\mathrm{b}}\end{array}$ & $\begin{array}{l}12.37 \pm 0.32^{a} \\
12.55 \pm 0.15^{b}\end{array}$ & June 2008 \\
\hline $\mathrm{CO}$ & Corsica, France & $\begin{array}{c}21 \\
20^{\mathrm{e}}\end{array}$ & $\begin{array}{l}42^{\circ} 21^{\prime} \mathrm{N} \\
42^{\circ} 38^{\prime} \mathrm{N}^{\mathrm{c}}\end{array}$ & $\begin{array}{c}08^{\circ} 32^{\prime} \mathrm{E} \\
08^{\circ} 54^{\prime} \mathrm{E}^{\mathrm{c}}\end{array}$ & $\begin{array}{l}17.34 \pm 3.26^{\mathbf{a}} \\
16.78 \pm 3.32^{\mathbf{b}}\end{array}$ & $\begin{array}{l}21.90 \pm 1.50^{\mathrm{a}} \\
22.73 \pm 0.46^{\mathrm{b}}\end{array}$ & $\begin{array}{l}13.38 \pm 1.44^{a} \\
13.00 \pm 0.09^{b}\end{array}$ & July 2008 \\
\hline $\mathbf{P F}$ & Portofino, Italy & $\begin{array}{c}50 \\
50^{\mathrm{f}}\end{array}$ & $\begin{array}{c}44^{\circ} 18^{\prime} \mathrm{N} \\
44^{\circ} 125^{\prime} \mathrm{N}^{\mathrm{d}}\end{array}$ & $\begin{array}{c}09^{\circ} 13^{\prime} \mathrm{E} \\
09^{\circ} 125^{\prime} \mathrm{E}^{\mathrm{d}}\end{array}$ & $14.61 \pm 1.32^{b}$ & $17.02 \pm 0.68^{b}$ & $13.07 \pm 0.05^{b}$ & May 2009 \\
\hline MS-43 & SW Malta & $\begin{array}{l}607 \\
600^{\mathrm{f}}\end{array}$ & $\begin{array}{c}35^{\circ} 30^{\prime} \mathrm{N} \\
35^{\circ} 375^{\prime} \mathrm{N}^{\mathrm{d}}\end{array}$ & $\begin{array}{c}14^{\circ} 06^{\prime} \mathrm{E} \\
14^{\circ} 125^{\prime} \mathrm{E}^{\mathrm{d}}\end{array}$ & $13.81 \pm 0.07^{\mathbf{b}}$ & $13.92 \pm 0.03^{b}$ & $13.68 \pm 0.02^{b}$ & December 2007 \\
\hline
\end{tabular}

${ }^{\mathrm{a}}$ Temperature values were sourced from T-MedNet network (www.t-mednet.org). Mean values represent the annual average $\pm 1 \sigma$ SD calculated using data for the period 2004-2014 (Medes Islands and Corsica) and 2003-2015 (Riou Island). Max T and Min T are the maximum and minimum monthly temperatures, after calculating the climatology of each site.

${ }^{\mathrm{b}}$ Temperature values were sourced from NOAA NODC WOA13 $\left(0.25^{\circ}\right.$ grid $)$. Mean values represent the annual average $\pm 1 \sigma$ SD calculated using data for the period 1955-2012. Max T and Min T are the maximum and minimum monthly temperatures, after calculating the climatology of each site.

${ }^{\mathrm{c}}$ Latitude and longitude of the site from the T-MedNet network (www.t-mednet.org) closest to the coral sampling location.

${ }^{\mathrm{d}}$ Sampling location coordinates from the NOAA NODC WOA $13\left(0.25^{\circ}\right.$ grid $)$ Atlas.

${ }^{\mathrm{e}}$ Sampling location depth from T-MedNet network (www.t-mednet.org).

${ }^{\mathrm{f}}$ Sampling location depth from the NOAA NODC WOA13 $\left(0.25^{\circ}\right.$ grid $)$ Atlas. 
Table 2. Sample diameter and age estimation of PF, MI, RI and MS-43 specimens, using different techniques.

\begin{tabular}{|c|c|c|c|c|c|c|}
\hline \multirow{2}{*}{ Sample } & \multicolumn{3}{|c|}{ Number of growth rings } & \multirow{2}{*}{$\begin{array}{c}\text { Diameter } \\
(\mathrm{mm})\end{array}$} & \multirow{2}{*}{$\begin{array}{c}\text { Mean growth } \\
\text { rate* }_{(\mu \mathrm{m} / \mathrm{yr})}\end{array}$} & \multirow{2}{*}{$\begin{array}{l}\text { Growth rate in the } \\
\text { annular zone } \\
(\mu \mathrm{m} / \mathrm{yr})\end{array}$} \\
\hline & $\begin{array}{l}\text { Petrographic } \\
\text { method }\end{array}$ & $\begin{array}{l}\text { SEM } \\
\text { (BSE) }\end{array}$ & OMS & & & \\
\hline RI & $11 \pm 2$ & $13 \pm 1$ & $18 \pm 2$ & $4.25 \pm 0.17$ & $236 \pm 27$ & $85 \pm 12$ \\
\hline MI & $21 \pm 2$ & $24 \pm 2$ & $30 \pm 1$ & $5.16 \pm 0.41$ & $172 \pm 7$ & $56 \pm 6$ \\
\hline PF & $20 \pm 2$ & $21 \pm 1$ & $27 \pm 6$ & $7.44 \pm 0.7$ & $276 \pm 65$ & $118 \pm 3$ \\
\hline MS-43 & $12 \pm 2$ & - & $70 \pm 4$ & $7.02 \pm 1.58$ & $95 \pm 75$ & $48 \pm 9$ \\
\hline
\end{tabular}

* Medullar zone included.

Growth rate values (mean $\pm 1 \mathrm{SD}$ ) represent the average of the growth rates calculated from different transects in the coral annular zone. SEM: Scanning Electron Microscope; BSE: Backscattered Electrons; OMS: Organic matrix staining 
Table 3. Element/Ca values for the C. rubrum samples MI, RI, CO and MS-43. Maximum, minimum and mean values for the entire coral cross section, comprising annular and medullar zones obtained by laser ablation and solution-based ICP-MS

\begin{tabular}{|c|c|c|c|c|c|}
\hline Sample & $\mathrm{Li} / \mathrm{Ca}(\mu \mathrm{mol} / \mathrm{mol})$ & $\mathrm{B} / \mathrm{Ca}(\mathrm{mmol} / \mathrm{mol})$ & $\mathrm{Mg} / \mathrm{Ca}(\mathrm{mmol} / \mathrm{mol})$ & $\mathrm{Sr} / \mathrm{Ca}(\mathrm{mmol} / \mathrm{mol})$ & $\mathrm{Ba} / \mathrm{Ca}(\mu \mathrm{mol} / \mathrm{mol})$ \\
\hline \multicolumn{6}{|l|}{$\underline{\mathbf{P F}}$} \\
\hline$\overline{\text { Mean }}$ & $39.54 \pm 0.28$ & $0.22 \pm 0.002$ & $122.52 \pm 0.61$ & $3.21 \pm 0.01$ & $6.15 \pm 0.22$ \\
\hline \multicolumn{6}{|l|}{$\underline{\text { MI }}$} \\
\hline$\overline{\operatorname{Max}}$ & 66.77 & 0.30 & 138.89 & 3.59 & 7.81 \\
\hline \multirow{2}{*}{ Min } & 28.61 & 0.17 & 103.21 & 3.00 & 6.11 \\
\hline & $(44.06 \pm 7.16 ; 49.41 \pm 6.40)$ & $(0.20 \pm 0.02 ; 0.22 \pm 0.03)$ & $(115.52 \pm 6.96 ; 130.47 \pm 4.25)$ & $(3.26 \pm 0.12 ; 3.40 \pm 0.07)$ & $(7.19 \pm 0.33 ; 6.79 \pm 0.18)$ \\
\hline \multirow{2}{*}{ Mean } & $45.28 \pm 7.34$ & $0.20 \pm 0.02$ & $118.92 \pm 8.99$ & $3.29 \pm 0.13$ & $7.10 \pm 0.35$ \\
\hline & $43.53 \pm 0.30$ & $0.21 \pm 0.002$ & $130.39 \pm 0.65$ & $3.33 \pm 0.01$ & $6.43 \pm 0.22$ \\
\hline \multicolumn{6}{|l|}{$\underline{\mathbf{R I}}$} \\
\hline$\overline{\operatorname{Max}}$ & 56.64 & 0.24 & 120.56 & 3.50 & 8.52 \\
\hline \multirow{2}{*}{ Min } & 31.46 & 0.16 & 98.20 & 2.83 & 5.39 \\
\hline & $(38.23 \pm 2.98 ; 43.87 \pm 5.27)$ & $(0.20 \pm 0.02 ; 0.20 \pm 0.02)$ & $(107.66 \pm 3.72 ; 109.84 \pm 3.76)$ & $(3.13 \pm 0.12 ; 3.17 \pm 0.10)$ & $(6.38 \pm 0.38 ; 6.93 \pm 0.67)$ \\
\hline \multirow{2}{*}{ Mean } & $39.50 \pm 4.32$ & $0.20 \pm 0.02$ & $108.16 \pm 3.84$ & $3.14 \pm 0.12$ & $6.50 \pm 0.52$ \\
\hline & $33.44 \pm 0.23$ & $0.24 \pm 0.003$ & $119.14 \pm 0.60$ & $3.12 \pm 0.01$ & $5.75 \pm 0.20$ \\
\hline \multicolumn{6}{|l|}{$\mathrm{CO}$} \\
\hline$\overline{\operatorname{Max}}$ & 45.93 & 0.31 & 127.19 & 3.34 & 7.15 \\
\hline Min & 24.69 & 0.20 & 102.30 & 2.75 & 5.55 \\
\hline \multirow{3}{*}{ Mean } & $(32.30 \pm 2.24 ; 33.75 \pm 3.60)$ & $(0.26 \pm 0.02 ; 0.26 \pm 0.02)$ & $(112.20 \pm 3.55 ; 115.86 \pm 4.27)$ & $(3.04 \pm 0.10 ; 3.07 \pm 0.10)$ & $(6.32 \pm 0.27 ; 6.41 \pm 0.22)$ \\
\hline & $32.72 \pm 2.78$ & $0.26 \pm 0.02$ & $113.25 \pm 4.12$ & $3.05 \pm 0.10$ & $6.34 \pm 0.26$ \\
\hline & $36.47 \pm 0.25$ & $0.25 \pm 0.003$ & $123.21 \pm 0.61$ & $3.10 \pm 0.01$ & $5.77 \pm 0.20$ \\
\hline \multicolumn{6}{|l|}{ MS-43 } \\
\hline$\overline{\operatorname{Max}}$ & 59.25 & 0.29 & 120.06 & 3.60 & 8.74 \\
\hline Min & 27.66 & 0.17 & 89.39 & 2.94 & 7.14 \\
\hline \multirow{3}{*}{ Mean } & $(31.93 \pm 1.78 ; 36.78 \pm 5.68)$ & $(0.21 \pm 0.02 ; 0.25 \pm 0.01)$ & $(102.30 \pm 2.88 ; 105.76 \pm 4.42)$ & $(3.22 \pm 0.10 ; 3.14 \pm 0.11)$ & $(7.81 \pm 0.23 ; 8.01 \pm 0.26)$ \\
\hline & $33.09 \pm 3.80$ & $0.21 \pm 0.02$ & $103.13 \pm 3.63$ & $3.20 \pm 0.10$ & $7.86 \pm 0.25$ \\
\hline & $32.30 \pm 0.23$ & $0.18 \pm 0.002$ & $115.70 \pm 0.58$ & $3.31 \pm 0.01$ & $7.84 \pm 0.27$ \\
\hline
\end{tabular}

Values in italics represent mean element/Ca ratio determined using solution-based ICP-MS

Values in parentheses represent the mean values for the annular (left) and medullar (right) zone

Sample PF was analyzed only by solution ICP-MS 
Table 4. Pearson product-moment correlation coefficient (r) for the element/Ca ratios obtained from the entire coral cross section, comprising annular and medullar zones of the analyzed C. rubrum specimens collected from the shallow-water of Riou Island (RI) and Corsica (CO) (transects 2 and 4 in figure 3 )

\begin{tabular}{|c|c|c|c|c|c|}
\hline Element/Ca & Sample & $\mathbf{L i} / \mathbf{C a}$ & $\mathbf{B} / \mathbf{C a}$ & $\mathrm{Mg} / \mathrm{Ca}$ & $\mathrm{Sr} / \mathrm{Ca}$ \\
\hline \multirow{2}{*}{$\mathbf{B} / \mathbf{C a}$} & RI & $\begin{array}{c}0.46 \\
(0.43-0.78)\end{array}$ & & & \\
\hline & $\mathrm{CO}$ & $\begin{array}{c}0.17 \\
(0.17-0.18)\end{array}$ & & & \\
\hline \multirow{2}{*}{$\mathrm{Mg} / \mathrm{Ca}$} & RI & $\begin{array}{c}0.40 \\
(0.24-0.55)\end{array}$ & $\begin{array}{c}0.55 \\
(0.56-0.58)\end{array}$ & & \\
\hline & $\mathrm{CO}$ & $\begin{array}{c}0.31 \\
(0.10-0.44)\end{array}$ & $\begin{array}{c}0.27 \\
(0.28-0.25)\end{array}$ & & \\
\hline \multirow{2}{*}{$\mathrm{Sr} / \mathrm{Ca}$} & RI & $\begin{array}{c}0.34 \\
(0.25-0.49)\end{array}$ & $\begin{array}{c}0.37 \\
(0.36-0.46)\end{array}$ & $\begin{array}{c}0.56 \\
(0.56-0.49)\end{array}$ & \\
\hline & $\mathrm{CO}$ & $\begin{array}{c}0.24 \\
(0.16-0.33)\end{array}$ & $\begin{array}{c}0.18 \\
(0.13-0.29)\end{array}$ & $\begin{array}{c}0.38 \\
(0.36-0.42)\end{array}$ & \\
\hline \multirow{2}{*}{$\mathrm{Ba} / \mathrm{Ca}$} & RI & $\begin{array}{c}0.41 \\
(0.33-0.11)\end{array}$ & $\begin{array}{c}-0.060 \\
(0.03--0.23)\end{array}$ & $\begin{array}{c}0.12 \\
\left(-0.04-0.15^{*}\right)\end{array}$ & $\begin{array}{c}0.31 \\
(0.31-0.23)\end{array}$ \\
\hline & $\mathrm{CO}$ & $\begin{array}{c}0.02 \\
(0.09--0.20)\end{array}$ & $\begin{array}{c}0.16 \\
(0.16-0.13)\end{array}$ & $\begin{array}{c}0.17 \\
\left(0.21--0.10^{*}\right)\end{array}$ & $\begin{array}{c}0.18 \\
(0.18-0.11 *)\end{array}$ \\
\hline
\end{tabular}

Values in parentheses represent the correlation coefficients for the annular (left) and medullar (right) zone.

All the correlations are significant at the 0.01 level (2-tailed), except $\mathrm{B} / \mathrm{Ca} v s$. Ba/Ca in the annular zone and the entire cross section for sample $\mathrm{RI}$, $\mathrm{Mg} / \mathrm{Ca} v s . \mathrm{Ba} / \mathrm{Ca}$ in the annular zone and $\mathrm{Li} / \mathrm{Ca} v s . \mathrm{Ba} / \mathrm{Ca}$ in the medullar zones for sample $\mathrm{RI}$ and $\mathrm{Li} / \mathrm{Ca} v$. $\mathrm{Ba} / \mathrm{Ca}$ for the entire cross section of the sample CO.

* Correlation is significant at the 0.05 level (2-tailed) 
Table 5. Pearson product-moment correlation coefficient (r) for the element/Ca ratios obtained from the entire coral cross section, comprising annular and medullar zones of C. rubrum specimen MS-43 collected from SW Malta (transect 8 in figure 3)

\begin{tabular}{ccccc}
\hline Element/Ca & $\mathbf{L i} / \mathbf{C a}$ & $\mathbf{B} / \mathbf{C a}$ & $\mathbf{M g} / \mathbf{C a}$ & $\mathbf{S r} / \mathbf{C a}$ \\
\hline $\mathbf{B} / \mathbf{C a}$ & 0.50 & & & \\
& $(0.19-0.28)$ & & & \\
$\mathbf{M g} / \mathbf{C a}$ & 0.59 & 0.15 & & \\
& $(-0.06-0.89)$ & $(-0.33-0.08)$ & & \\
$\mathbf{S r} / \mathbf{C a}$ & 0.10 & -0.33 & 0.18 & \\
& $\left(0.08^{*}-0.66\right)$ & $\left(-0.27-0.17^{*}\right)$ & $(0.15-0.75)$ & -0.05 \\
$\mathbf{B a} / \mathbf{C a}$ & 0.38 & 0.52 & 0.01 & $(0.03-0.12)$ \\
\hline
\end{tabular}

Values in parentheses represent the correlation coefficients for the annular (left) and medullar (right) zone.

All the correlations are significant at the 0.01 level (2-tailed), except $\mathrm{Sr} / \mathrm{Ca} v s . \mathrm{Ba} / \mathrm{Ca}$ and $\mathrm{Mg} / \mathrm{Ca} v s$. $\mathrm{Ba} / \mathrm{Ca}$ for the entire cross section, $\mathrm{Sr} / \mathrm{Ca} v s$. $\mathrm{Ba} / \mathrm{Ca}$ and $\mathrm{Li} / \mathrm{Ca}$ s. $\mathrm{Mg} / \mathrm{Ca}$ in the annular zone, and $\mathrm{B} / \mathrm{Ca}$ s. $\mathrm{Mg} / \mathrm{Ca}$ and $\mathrm{Sr} / \mathrm{Ca} v s . \mathrm{Ba} / \mathrm{Ca}$ in the medullar zone.

* Correlation is significant at the 0.05 level (2-tailed) 
Table 6. Pearson product-moment correlation coefficient (r) between the thickness of the growth bands and the element/Ca ratios obtained from the annular zone of C. rubrum specimen MI from Medes Islands (transect 6 in figure 3)

\begin{tabular}{|c|c|c|c|c|c|}
\hline & Thickness & $\mathbf{L i} / \mathbf{C a}$ & $\mathbf{B} / \mathbf{C a}$ & $\mathrm{Mg} / \mathrm{Ca}$ & $\mathrm{Sr} / \mathrm{Ca}$ \\
\hline $\mathbf{L i} / \mathbf{C a}$ & $\begin{array}{c}0.22 \\
(0.22-0.09)\end{array}$ & & & & \\
\hline $\mathbf{B} / \mathbf{C a}$ & $\begin{array}{c}0.23 \\
(0.25--0.001)\end{array}$ & $\begin{array}{c}0.11 \\
(0.07-0.09)\end{array}$ & & & \\
\hline $\mathrm{Mg} / \mathrm{Ca}$ & $\begin{array}{c}0.45^{*} \\
(0.29--0.11)\end{array}$ & $\begin{array}{c}0.59^{*} \\
\left(0.64^{*}-0.59^{*}\right)\end{array}$ & $\begin{array}{c}0.36^{*} \\
\left(0.11-0.46^{* *}\right)\end{array}$ & & \\
\hline $\mathrm{Sr} / \mathrm{Ca}$ & $\begin{array}{c}0.35^{*} \\
(0.34-0.03)\end{array}$ & $\begin{array}{c}0.65^{*} \\
\left(0.77^{*}-0.58^{*}\right)\end{array}$ & $\begin{array}{c}0.30^{*} \\
(0.15-0.29)\end{array}$ & $\begin{array}{c}0.76^{*} \\
\left(0.88^{*}-0.66^{*}\right)\end{array}$ & \\
\hline $\mathrm{Ba} / \mathrm{Ca}$ & $\begin{array}{c}0.23 \\
(-0.13-0.25)\end{array}$ & $\begin{array}{c}0.24 \\
(0.22-0.19)\end{array}$ & $\begin{array}{c}-0.21 \\
\left(-0.50^{*}--0.22\right)\end{array}$ & $\begin{array}{c}0.08 \\
(-0.14--0.12)\end{array}$ & $\begin{array}{c}0.10 \\
(0.01--0.04)\end{array}$ \\
\hline
\end{tabular}

Values in parentheses represent the correlation coefficients for the light (left) and dark (right) increments.

* Correlation is significant at the 0.01 level

** Correlation is significant at the 0.05 level 
Table 7. Winter (from November to February) and summer (from March to October) temperatures from T-MedNet, thickness of dark (DB) and light (LB) growth bands and their corresponding $\mathrm{Mg} / \mathrm{Ca}$ values obtained by laser ablation ICP-MS along the transects 2, 4 and 6 of the samples RI, $\mathrm{CO}$ and MI, respectively (see figure 3 for position of the laser tracks). The $\mathrm{Mg} / \mathrm{Ca}$ values were calculated by averaging the values from both sides of the transect (error $= \pm 1 \sigma \mathrm{SD})$.

MI RI CO

\begin{tabular}{|c|c|c|c|c|c|c|c|c|c|c|}
\hline Band & Year & $\begin{array}{c}\mathrm{Mg} / \mathrm{Ca} \\
(\mathrm{mmol} / \mathrm{mol})\end{array}$ & $\begin{array}{c}\text { Band } \\
\text { Thickness } \\
(\mu \mathrm{m})\end{array}$ & $\begin{array}{c}\text { Temperature } \\
\left({ }^{\circ} \mathrm{C}\right)\end{array}$ & $\begin{array}{c}\mathrm{Mg} / \mathrm{Ca} \\
(\mathrm{mmol} / \mathrm{mol})\end{array}$ & $\begin{array}{c}\text { Band } \\
\text { Thickness } \\
(\mu \mathrm{m})\end{array}$ & $\begin{array}{c}\text { Temperature } \\
\left({ }^{\circ} \mathrm{C}\right)\end{array}$ & $\begin{array}{c}\mathrm{Mg} / \mathrm{Ca} \\
(\mathrm{mmol} / \mathrm{mol})\end{array}$ & $\begin{array}{c}\text { Band } \\
\text { Thickness } \\
(\mu \mathrm{m})\end{array}$ & $\begin{array}{c}\text { Temperature } \\
\left({ }^{\circ} \mathbf{C}\right)\end{array}$ \\
\hline LB & 2008 & $118.19 \pm 1.07$ & $31 \pm 16$ & $17.54 \pm 0.98$ & - & & - & - & & - \\
\hline DB & 2008 & $118.52 \pm 1.54$ & $7 \pm 3$ & - & $117.74 \pm 1.52$ & $61 \pm 53$ & $14.87 \pm 1.24$ & $122.69 \pm 2.97$ & $26 \pm 30$ & $14.77 \pm 1.74$ \\
\hline LB & 2007 & $121.68 \pm 1.12$ & $49 \pm 4$ & $17.73 \pm 3.05$ & $119.99 \pm 2.50$ & $80 \pm 46$ & $17.16 \pm 2.06$ & $125.57 \pm 2.93$ & $89 \pm 27$ & $18.72 \pm 3.05$ \\
\hline DB & 2007 & $121.34 \pm 0.98$ & $7 \pm 3$ & $15.37 \pm 2.11$ & $116.18 \pm 0.47$ & $75 \pm 66$ & $16.15 \pm 1.99$ & $119.42 \pm 1.92$ & $33 \pm 13$ & $16.76 \pm 2.22$ \\
\hline LB & 2006 & $120.92 \pm 1.49$ & $52 \pm 40$ & $17.54 \pm 3.71$ & $120.77 \pm 2.38$ & $113 \pm 27$ & $17.40 \pm 3.44$ & $123.48 \pm 2.20$ & $116 \pm 43$ & $17.847 \pm 3.26$ \\
\hline DB & 2006 & $118.49 \pm 1.54$ & $28 \pm 13$ & $13.61 \pm 2.45$ & $118.42 \pm 0.58$ & $29 \pm 13$ & $14.69 \pm 2.70$ & $118.16 \pm 1.20$ & $29 \pm 13$ & $14.92 \pm 2.83$ \\
\hline LB & 2005 & $121.49 \pm 0.88$ & $105 \pm 24$ & $17.24 \pm 3 / 35$ & $121.29 \pm 1.77$ & $119 \pm 42$ & $17.00 \pm 2.88$ & $120.18 \pm 1.88$ & $66 \pm 13$ & $19.39 \pm 2.09$ \\
\hline DB & 2005 & $119.95 \pm 0.27$ & $19 \pm 13$ & $13.91 \pm 1.82$ & $117.17 \pm 1.03$ & $17 \pm 4$ & $15.05 \pm 2.02$ & $119.69 \pm 2.05$ & $17 \pm 4$ & - \\
\hline LB & 2004 & $120.61 \pm 1.31$ & $89 \pm 46$ & $19.99 \pm 0.93$ & $120.76 \pm 2.55$ & $66 \pm 6$ & $19.03 \pm 1.43$ & $123.66 \pm 1.75$ & $105 \pm 76$ & - \\
\hline DB & 2004 & $118.22 \pm 0.41$ & $21 \pm 3$ & - & $117.74 \pm 1.63$ & $14 \pm 7$ & - & $120.66 \pm 1.91$ & 23 & - \\
\hline LB & 2003 & $119.44 \pm 1.72$ & $54 \pm 23$ & - & $119.27 \pm 1.66$ & $141 \pm 106$ & - & $122.32 \pm 1.91$ & $76 \pm 26$ & - \\
\hline
\end{tabular}


Table 8. Monthly temperature from T-MedNet and corresponding $\mathrm{Mg} / \mathrm{Ca}$ values obtained by laser ablation ICP-MS along the transects 2 , 4 and 6 of the samples RI, CO and MI, respectively (see figure 3 for position of the laser tracks). The $\mathrm{Mg} / \mathrm{Ca}$ values were calculated by averaging the values from both sides of the transect (error $= \pm 1 \sigma \mathrm{SD}$ ).

\begin{tabular}{|c|c|c|c|c|c|c|c|c|}
\hline \multicolumn{3}{|c|}{ RI } & \multicolumn{3}{|c|}{ MI } & \multicolumn{3}{|c|}{$\mathrm{CO}$} \\
\hline Month & $\begin{array}{c}\text { Temperature } \\
\left({ }^{\circ} \mathrm{C}\right)\end{array}$ & $\begin{array}{c}\mathrm{Mg} / \mathrm{Ca} \\
(\mathbf{m m o l} / \mathbf{m o l})\end{array}$ & Month & $\begin{array}{c}\text { Temperature } \\
\left({ }^{\circ} \mathbf{C}\right)\end{array}$ & $\begin{array}{c}\mathrm{Mg} / \mathrm{Ca} \\
(\mathbf{m m o l} / \mathbf{m o l})\end{array}$ & Month & $\begin{array}{c}\text { Temperature } \\
\left({ }^{\circ} \mathbf{C}\right)\end{array}$ & $\begin{array}{c}\mathrm{Mg} / \mathrm{Ca} \\
(\mathbf{m m o l} / \mathrm{mol})\end{array}$ \\
\hline $01 / 2008$ & $13.70 \pm 0.21$ & $116.72 \pm 3.93$ & 07/2008 & - & $119.49 \pm 0.30$ & $02 / 2008$ & $13.52 \pm 0.14$ & $118.55 \pm 4.34$ \\
\hline $12 / 2007$ & $14.74 \pm 0.46$ & $117.01 \pm 3.33$ & $06 / 2008$ & $18.23 \pm 1.18$ & $119.22 \pm 0.24$ & $01 / 2008$ & $13.67 \pm 0.17$ & $122.72 \pm 5.47$ \\
\hline $11 / 2007$ & $16.16 \pm 1.22$ & $119.48 \pm 1.80$ & $05 / 2008$ & $16.84 \pm 0.38$ & $117.35 \pm 0.71$ & $12 / 2007$ & $14.61 \pm 0.61$ & $125.34 \pm 5.30$ \\
\hline $10 / 2007$ & $19.79 \pm 0.87$ & $118.90 \pm 2.35$ & $04 / 2008$ & - & $117.55 \pm 1.84$ & $11 / 2007$ & $17.29 \pm 1.28$ & $124.17 \pm 3.90$ \\
\hline 09/2007 & $19.31 \pm 2.54$ & $119.59 \pm 2.47$ & 03/2008 & - & $117.34 \pm 0.58$ & $10 / 2007$ & $20.42 \pm 0.86$ & $125.00 \pm 4.84$ \\
\hline 08/2007 & $18.35 \pm 2.46$ & $119.79 \pm 1.71$ & $02 / 2008$ & - & $117.37 \pm 0.27$ & 09/2007 & $22.02 \pm 0.64$ & $126.86 \pm 4.94$ \\
\hline 07/2007 & $17.11 \pm 2.33$ & $120.32 \pm 3.50$ & $01 / 2008$ & - & $117.27 \pm 1.87$ & $08 / 2007$ & $21.90 \pm 0.90$ & $128.11 \pm 5.79$ \\
\hline 06/2007 & $17.64 \pm 2.38$ & $125.58 \pm 3.35$ & $12 / 2007$ & - & $118.89 \pm 1.99$ & $07 / 2007$ & $20.74 \pm 1.60$ & $128.38 \pm 5.78$ \\
\hline $05 / 2007$ & $16.30 \pm 1.57$ & $120.39 \pm 6.04$ & $11 / 2007$ & - & $120.54 \pm 1.46$ & $06 / 2007$ & $18.54 \pm 1.57$ & $127.53 \pm 4.20$ \\
\hline $04 / 2007$ & $14.88 \pm 1.04$ & $117.81 \pm 5.42$ & $10 / 2007$ & $18.30 \pm 0.41$ & $120.43 \pm 0.31$ & $05 / 2007$ & $16.99 \pm 1.08$ & $126.11 \pm 2.00$ \\
\hline 03/2007 & $13.89 \pm 0.20$ & $117.54 \pm 2.75$ & 09/2007 & $19.44 \pm 0.63$ & $120.13 \pm 0.83$ & $04 / 2007$ & $14.77 \pm 0.44$ & $122.37 \pm 1.31$ \\
\hline $02 / 2007$ & $14.23 \pm 0.20$ & $116.42 \pm 2.16$ & $08 / 2007$ & $21.72 \pm 0.75$ & $120.95 \pm 0.83$ & $03 / 2007$ & $14.41 \pm 0.21$ & $120.17 \pm 0.88$ \\
\hline $01 / 2007$ & $14.87 \pm 0.46$ & $116.25 \pm 1.00$ & $07 / 2007$ & $20.66 \pm 1.44$ & $121.49 \pm 0.53$ & $02 / 2007$ & $14.49 \pm 0.14$ & $116.98 \pm 1.35$ \\
\hline $12 / 2006$ & $16.88 \pm 0.63$ & $115.51 \pm 0.55$ & $06 / 2007$ & $17.99 \pm 1.72$ & $122.81 \pm 0.39$ & $01 / 2007$ & $15.54 \pm 0.43$ & $119.07 \pm 0.32$ \\
\hline $11 / 2006$ & $18.60 \pm 1.09$ & $116.55 \pm 0.19$ & $05 / 2007$ & $16.71 \pm 0.66$ & $122.85 \pm 0.04$ & $12 / 2006$ & $17.48 \pm 0.69$ & $120.03 \pm 2.58$ \\
\hline $10 / 2006$ & $20.15 \pm 1.58$ & $117.58 \pm 0.82$ & $04 / 2007$ & $13.82 \pm 0.77$ & $122.91 \pm 0.09$ & $11 / 2006$ & $19.52 \pm 0.74$ & $121.58 \pm 1.12$ \\
\hline
\end{tabular}




\begin{tabular}{|c|c|c|c|c|c|c|c|c|}
\hline 09/2006 & $20.76 \pm 2.04$ & $119.42 \pm 1.38$ & $03 / 2007$ & $13.17 \pm 0.27$ & $121.86 \pm 1.13$ & $10 / 2006$ & $21.39 \pm 0.52$ & $122.42 \pm 1.97$ \\
\hline 08/2006 & $16.45 \pm 2.09$ & $119.07 \pm 1.10$ & $02 / 2007$ & $13.27 \pm 0.26$ & $121.16 \pm 0.55$ & 09/2006 & $20.89 \pm 1.69$ & $124.20 \pm 1.25$ \\
\hline 07/2006 & $21.86 \pm 1.91$ & $119.17 \pm 0.27$ & $01 / 2007$ & $14.36 \pm 0.38$ & $120.51 \pm 1.72$ & $08 / 2006$ & $20.70 \pm 2.14$ & $124.99 \pm 2.03$ \\
\hline 06/2006 & $18.61 \pm 2.54$ & $121.19 \pm 0.88$ & $12 / 2006$ & $15.72 \pm 0.81$ & $122.75 \pm 0.15$ & $07 / 2006$ & $19.42 \pm 0.76$ & $126.08 \pm 2.85$ \\
\hline 05/2006 & $15.07 \pm 1.01$ & $123.65 \pm 2.86$ & $11 / 2006$ & $18.15 \pm 0.57$ & $120.93 \pm 2.26$ & $06 / 2006$ & $17.39 \pm 2.03$ & $125.43 \pm 1.41$ \\
\hline $04 / 2006$ & $13.61 \pm 0.67$ & $124.36 \pm 7.19$ & $10 / 2006$ & $19.10 \pm 0.37$ & $122.19 \pm 0.03$ & $05 / 2006$ & $15.98 \pm 0.85$ & $123.44 \pm 0.53$ \\
\hline 03/2006 & $12.70 \pm 0.31$ & $121.71 \pm 6.47$ & $09 / 2006$ & $19.09 \pm 1.16$ & $121.18 \pm 3.46$ & $04 / 2006$ & $14.05 \pm 0.55$ & $121.87 \pm 1.63$ \\
\hline $02 / 2006$ & $12.71 \pm 0.15$ & $118.89 \pm 4.88$ & $08 / 2006$ & $22.26 \pm 2.88$ & $123.32 \pm 0.20$ & $03 / 2006$ & $12.95 \pm 0.22$ & $119.40 \pm 2.50$ \\
\hline $01 / 2006$ & $13.06 \pm 0.14$ & $117.67 \pm 2.60$ & $07 / 2006$ & $21.15 \pm 1.71$ & $120.21 \pm 3.14$ & $02 / 2006$ & $12.91 \pm 0.10$ & $116.82 \pm 1.73$ \\
\hline $12 / 2005$ & $14.42 \pm 0.74$ & $118.23 \pm 1.42$ & - & $18.24 \pm 1.90$ & - & $01 / 2006$ & $13.18 \pm 0.20$ & $117.47 \pm 2.95$ \\
\hline $11 / 2005$ & $18.58 \pm 0.85$ & $118.86 \pm 0.84$ & $05 / 2006$ & $15.43 \pm 0.96$ & $120.74 \pm 0.65$ & $12 / 2005$ & $14.58 \pm 0.98$ & $119.20 \pm 4.31$ \\
\hline $10 / 2005$ & $18.88 \pm 1.69$ & $120.74 \pm 1.59$ & $04 / 2006$ & $13.21 \pm 0.80$ & $120.02 \pm 0.84$ & $11 / 2005$ & $19.02 \pm 1.42$ & $119.15 \pm 3.36$ \\
\hline 09/2005 & $21.28 \pm 2.36$ & $122.60 \pm 4.81$ & $03 / 2006$ & $11.82 \pm 0.44$ & $118.80 \pm 1.10$ & $10 / 2005$ & $20.52 \pm 0.38$ & $120.64 \pm 2.33$ \\
\hline 08/2005 & $17.93 \pm 3.30$ & $123.83 \pm 3.04$ & $02 / 2006$ & $11.45 \pm 0.38$ & $117.93 \pm 1.67$ & 09/2005 & $21.26 \pm 1.79$ & $121.88 \pm 2.61$ \\
\hline 07/2005 & $17.42 \pm 3.56$ & $122.66 \pm 3.22$ & $01 / 2006$ & $12.09 \pm 0.42$ & $116.88 \pm 1.57$ & $08 / 2005$ & $20.90 \pm 2.33$ & $123.02 \pm 1.91$ \\
\hline 06/2005 & $18.80 \pm 2.24$ & $122.14 \pm 6.74$ & $12 / 2005$ & $13.99 \pm 0.83$ & $118.59 \pm 2.36$ & $07 / 2005$ & $19.76 \pm 2.13$ & $121.33 \pm 1.77$ \\
\hline $05 / 2005$ & $15.26 \pm 1.16$ & $119.94 \pm 7.12$ & $11 / 2005$ & $16.91 \pm 0.83$ & $120.54 \pm 2.44$ & $06 / 2005$ & $18.09 \pm 1.44$ & $119.82 \pm 3.08$ \\
\hline $04 / 2005$ & $13.50 \pm 0.25$ & $119.64 \pm 7.14$ & $10 / 2005$ & $17.92 \pm 0.49$ & $120.58 \pm 1.57$ & $05 / 2005$ & $15.79 \pm 1.34$ & $118.99 \pm 3.66$ \\
\hline 03/2005 & $12.91 \pm 0.29$ & $118.76 \pm 6.80$ & $09 / 2005$ & $19.61 \pm 1.04$ & $121.32 \pm 1.35$ & $04 / 2005$ & & $118.18 \pm 0.64$ \\
\hline $02 / 2005$ & $12.92 \pm 0.32$ & $117.09 \pm 8.74$ & $08 / 2005$ & $20.79 \pm 1.20$ & $120.59 \pm 0.16$ & $03 / 2005$ & & $117.57 \pm 1.93$ \\
\hline $01 / 2005$ & $14.08 \pm 0.48$ & $116.85 \pm 6.77$ & $07 / 2005$ & $20.93 \pm 2.05$ & $121.28 \pm 0.27$ & $02 / 2005$ & & $116.85 \pm 0.77$ \\
\hline $12 / 2004$ & $15.63 \pm 0.74$ & $118.58 \pm 8.29$ & $06 / 2005$ & $18.08 \pm 1.07$ & $122.59 \pm 1.57$ & $01 / 2005$ & & $120.15 \pm 0.75$ \\
\hline $11 / 2004$ & $17.58 \pm 1.30$ & $116.14 \pm 2.02$ & $05 / 2005$ & $15.15 \pm 0.86$ & $122.27 \pm 1.13$ & $12 / 2004$ & $15.98 \pm 0.77$ & $120.02 \pm 0.64$ \\
\hline $10 / 2004$ & $20.41 \pm 0.91$ & $122.01 \pm 8.02$ & $04 / 2005$ & $12.94 \pm 0.26$ & $122.62 \pm 0.45$ & $11 / 2004$ & $18.61 \pm 1.43$ & $121.74 \pm 1.80$ \\
\hline
\end{tabular}




\begin{tabular}{|c|c|c|c|c|c|c|c|c|}
\hline 09/2004 & $19.58 \pm 3.25$ & $122.74 \pm 10.63$ & 03/2005 & $12.46 \pm 0.40$ & $120.68 \pm 1.50$ & $10 / 2004$ & $21.46 \pm 0.48$ & $123.67 \pm 0.83$ \\
\hline $08 / 2004$ & $19.09 \pm 3.61$ & $121.95 \pm 9.41$ & $02 / 2005$ & $11.92 \pm 0.33$ & $120.17 \pm 0.49$ & $09 / 2004$ & $22.68 \pm 1.72$ & $122.36 \pm 0.32$ \\
\hline $07 / 2004$ & $17.05 \pm 2.65$ & $123.01 \pm 7.69$ & $01 / 2005$ & $13.09 \pm 0.38$ & $119.67 \pm 2.30$ & $08 / 2004$ & $22.54 \pm 1.64$ & $124.09 \pm 0.52$ \\
\hline $06 / 2004$ & & $122.81 \pm 8.05$ & $12 / 2004$ & $14.49 \pm 0.43$ & $119.78 \pm 2.31$ & $07 / 2004$ & & $124.49 \pm 0.92$ \\
\hline $05 / 2004$ & & $118.01 \pm 4.27$ & $11 / 2004$ & $16.15 \pm 1.36$ & $120.19 \pm 4.06$ & $06 / 2004$ & & $126.70 \pm 1.29$ \\
\hline $04 / 2004$ & & $116.37 \pm 2.56$ & $10 / 2004$ & $18.61 \pm 0.68$ & $120.31 \pm 3.26$ & $05 / 2004$ & & $124.45 \pm 0.61$ \\
\hline $03 / 2004$ & & $119.20 \pm 1.16$ & 09/2004 & $20.38 \pm 1.42$ & $121.89 \pm 1.14$ & $04 / 2004$ & & $122.75 \pm 1.78$ \\
\hline $02 / 2004$ & & $115.66 \pm 0.97$ & $08 / 2004$ & $20.60 \pm 2.18$ & $121.32 \pm 0.92$ & $03 / 2004$ & & $120.78 \pm 3.52$ \\
\hline $01 / 2004$ & & $117.22 \pm 0.28$ & $07 / 2004$ & $20.39 \pm 2.23$ & $122.48 \pm 0.29$ & $02 / 2004$ & & $118.72 \pm 4.47$ \\
\hline $12 / 2003$ & & $118.98 \pm 1.34$ & $06 / 2004$ & & $120.79 \pm 0.37$ & $01 / 2004$ & & $120.18 \pm 5.38$ \\
\hline $11 / 2003$ & & $119.09 \pm 0.09$ & $05 / 2004$ & & $120.26 \pm 1.13$ & $12 / 2003$ & & $120.47 \pm 5.91$ \\
\hline $10 / 2003$ & & $118.69 \pm 2.24$ & $04 / 2004$ & & $119.37 \pm 0.40$ & $11 / 2003$ & & $123.29 \pm 6.64$ \\
\hline 09/2003 & & $121.09 \pm 2.60$ & $03 / 2004$ & & $118.46 \pm 1.23$ & $10 / 2003$ & & $123.29 \pm 5.83$ \\
\hline $08 / 2003$ & & $120.88 \pm 4.84$ & $02 / 2004$ & & $118.17 \pm 2.18$ & $09 / 2003$ & & $123.22 \pm 4.69$ \\
\hline $07 / 2003$ & & $120.39 \pm 4.10$ & $01 / 2004$ & & $117.68 \pm 4.23$ & $08 / 2003$ & & $124.00 \pm 4.48$ \\
\hline $06 / 2003$ & & $120.39 \pm 3.17$ & $12 / 2003$ & & $118.65 \pm 2.15$ & $07 / 2003$ & & $124.07 \pm 4.41$ \\
\hline $05 / 2003$ & & $118.76 \pm 1.73$ & $11 / 2003$ & & $118.38 \pm 1.02$ & $06 / 2003$ & & $122.05 \pm 5.25$ \\
\hline $04 / 2003$ & & $117.14 \pm 1.96$ & $10 / 2003$ & & $120.35 \pm 0.23$ & $05 / 2003$ & & $118.98 \pm 0.65$ \\
\hline $03 / 2003$ & & $116.86 \pm 1.87$ & 09/2003 & & $120.30 \pm 0.52$ & $04 / 2003$ & & $120.59 \pm 6.61$ \\
\hline $02 / 2003$ & & $114.63 \pm 1.63$ & $08 / 2003$ & & $121.62 \pm 0.62$ & & & \\
\hline
\end{tabular}


Table S1. Monthly T-means time-series records in the NW Mediterranean sampling sites sourced from T-MedNet database (www.t-mednet.org) and NOAA NODC WOA13 (0.25 grid) databases, and the corresponding C. rubrum mean $\mathrm{Mg} / \mathrm{Ca}$ values from each site

\begin{tabular}{cccccc}
\hline Month & MI & RI & CO & PF & MS-43 \\
\hline January & $13.18 \pm 0.39$ & $14.13 \pm 0.26$ & $13.93 \pm 0.32$ & $13.49 \pm 0.11$ & $13.77 \pm 0.05$ \\
February & $12.21 \pm 0.32$ & $13.64 \pm 0.13$ & $13.31 \pm 0.18$ & $13.07 \pm 0.05$ & $13.92 \pm 0.03$ \\
March & $12.48 \pm 0.37$ & $13.65 \pm 0.20$ & $13.13 \pm 0.26$ & $13.13 \pm 0.01$ & $13.86 \pm 0.02$ \\
April & $13.32 \pm 0.61$ & $14.38 \pm 0.50$ & $13.84 \pm 0.58$ & $13.38 \pm 0.09$ & $13.80 \pm 0.03$ \\
May & $16.03 \pm 0.72$ & $16.27 \pm 1.04$ & $15.74 \pm 1.22$ & $14.28 \pm 0.10$ & $13.73 \pm 0.02$ \\
June & $18.14 \pm 1.47$ & $18.08 \pm 1.49$ & $18.22 \pm 2.18$ & $13.55 \pm 0.08$ & $13.88 \pm 0.01$ \\
July & $20.78 \pm 1.86$ & $20.10 \pm 1.50$ & $18.36 \pm 2.61$ & $14.48 \pm 0.15$ & $13.68 \pm 0.02$ \\
August & $21.34 \pm 1.75$ & $21.51 \pm 1.75$ & $17.95 \pm 2.86$ & $14.74 \pm 0.01$ & $13.78 \pm 0.03$ \\
September & $19.63 \pm 1.06$ & $21.71 \pm 1.46$ & $21.23 \pm 2.55$ & $14.90 \pm 0.22$ & $13.78 \pm 0.03$ \\
October & $18.48 \pm 0.49$ & $20.95 \pm 0.56$ & $19.81 \pm 1.26$ & $17.02 \pm 0.68$ & $13.83 \pm 0.02$ \\
November & $17.07 \pm 0.92$ & $18.61 \pm 1.22$ & $17.73 \pm 1.12$ & $16.86 \pm 0.13$ & $13.83 \pm 0.01$ \\
December & $14.73 \pm 0.69$ & $15.66 \pm 0.76$ & $15.42 \pm 0.64$ & $14.35 \pm 0.26$ & $13.80 \pm 0.03$ \\
Mg/Ca (mmol/mol) & $130.39 \pm 11.69^{\mathrm{a}}$ & $119.14 \pm 9.80^{\mathrm{a}}$ & $123.21 \pm 10.91^{\mathrm{a}}$ & $122.52^{\mathrm{b}}$ & $115.70 \pm 6.12^{\mathrm{a}}$ \\
\hline
\end{tabular}

Seawater temperature values for samples MI, RI and CO were sourced from T-MedNet network (www.t-mednet.org; from 2004 to 2008 ). Seawater temperature values for samples PF and MS-43 were sourced from NOAA NODC WOA13 (0.25 grid) Atlas (from1955 to 2012$)$. ${ }^{a}$ Mean value from LA-ICP-MS analysis (after correction from solution ICP-MS).

${ }^{\mathrm{b}}$ Mean value from solution ICP-MS analysis. 
Table S2. Dark (DB) and light (LB) growth bands thickness $(\mu \mathrm{m})$ obtained from a transect along the cross-section of samples MS-43, RI, MI and PF

\begin{tabular}{|c|c|c|c|c|c|c|c|c|c|c|c|}
\hline \multirow{2}{*}{ Year } & \multicolumn{2}{|c|}{ MS-43 } & \multirow{2}{*}{ Year } & \multicolumn{2}{|c|}{ RI } & \multirow{2}{*}{ Year } & \multicolumn{2}{|c|}{ MI } & \multirow{2}{*}{ Year } & \multicolumn{2}{|c|}{ PF } \\
\hline & LB & DB & & LB & DB & & LB & DB & & LB & DB \\
\hline 2008 & 32 & 19 & 2008 & 48 & 36 & 2008 & 23 & 28 & 2009 & 15 & 27 \\
\hline 2007 & 19 & 15 & 2007 & 27 & 48 & 2007 & 23 & 9 & 2008 & 33 & 21 \\
\hline 2006 & 36 & 13 & 2006 & 32 & 35 & 2006 & 79 & 19 & 2007 & 88 & 22 \\
\hline 2005 & 32 & 11 & 2005 & 32 & 35 & 2005 & 79 & 23 & 2006 & 54 & 24 \\
\hline 2004 & 19 & 13 & 2004 & 46 & 46 & 2004 & 56 & 5 & 2005 & 51 & 34 \\
\hline 2003 & 18 & 4 & 2003 & 54 & 23 & 2003 & 56 & 9 & 2004 & 112 & 13 \\
\hline 2002 & 34 & 13 & 2002 & 15 & 19 & 2002 & 28 & 19 & 2003 & 22 & 38 \\
\hline 2001 & 22 & 22 & 2001 & 46 & 33 & 2001 & 79 & 14 & 2002 & 32 & 12 \\
\hline 2000 & 35 & 22 & 2000 & 87 & 44 & 2000 & 28 & 9 & 2001 & 36 & 34 \\
\hline 1999 & 15 & 7 & 1999 & 39 & 35 & 1999 & 19 & 9 & 2000 & 30 & 26 \\
\hline 1998 & 27 & 14 & 1998 & 82 & 35 & 1998 & 42 & 9 & 1999 & 111 & 20 \\
\hline 1997 & 34 & 11 & 1997 & 32 & 41 & 1997 & 37 & 14 & 1998 & 42 & 26 \\
\hline 1996 & 22 & 15 & 1996 & 35 & 20 & 1996 & 23 & 5 & 1997 & 26 & 21 \\
\hline 1995 & 27 & 9 & 1995 & 41 & 20 & 1995 & 33 & 14 & 1996 & 78 & 18 \\
\hline 1994 & 32 & 11 & 1994 & 41 & 31 & 1994 & 79 & 14 & 1995 & 92 & 47 \\
\hline 1993 & 30 & 15 & 1993 & 67 & 42 & 1993 & 33 & 9 & 1994 & 43 & 27 \\
\hline 1992 & 15 & 9 & 1992 & 77 & 21 & 1992 & 56 & 19 & 1993 & 62 & 38 \\
\hline 1991 & 22 & 8 & 1991 & 71 & 29 & 1991 & 89 & 9 & 1992 & 74 & 22 \\
\hline 1990 & 33 & 12 & 1990 & 18 & 26 & 1990 & 28 & 5 & 1991 & 72 & 25 \\
\hline 1989 & 43 & 19 & 1989 & 29 & 19 & 1989 & 163 & 61 & 1990 & 54 & 24 \\
\hline 1988 & 22 & 11 & & & & 1988 & 61 & 5 & 1989 & 77 & 16 \\
\hline 1987 & 28 & 13 & & & & 1987 & 42 & 19 & 1988 & 29 & 24 \\
\hline 1986 & 25 & 9 & & & & 1986 & 56 & 9 & 1987 & 31 & 14 \\
\hline 1985 & 22 & 12 & & & & 1985 & 47 & 9 & 1986 & 55 & 29 \\
\hline 1984 & 22 & 12 & & & & 1984 & 42 & 5 & 1985 & 71 & 17 \\
\hline 1983 & 41 & 12 & & & & 1983 & 79 & 14 & 1984 & 29 & 22 \\
\hline 1982 & 20 & 12 & & & & 1982 & 47 & 14 & 1983 & 37 & 14 \\
\hline 1981 & 25 & 12 & & & & 1981 & 47 & 5 & 1982 & 111 & 23 \\
\hline 1980 & 25 & 8 & & & & 1980 & 112 & 14 & 1981 & 122 & 36 \\
\hline 1979 & 30 & 12 & & & & & & & 1980 & 132 & 33 \\
\hline 1978 & 30 & 22 & & & & & & & 1979 & 263 & 45 \\
\hline 1977 & 48 & 20 & & & & & & & & & \\
\hline 1976 & 20 & 16 & & & & & & & & & \\
\hline 1975 & 37 & 28 & & & & & & & & & \\
\hline 1974 & 19 & 11 & & & & & & & & & \\
\hline 1973 & 42 & 17 & & & & & & & & & \\
\hline 1972 & 36 & 19 & & & & & & & & & \\
\hline
\end{tabular}




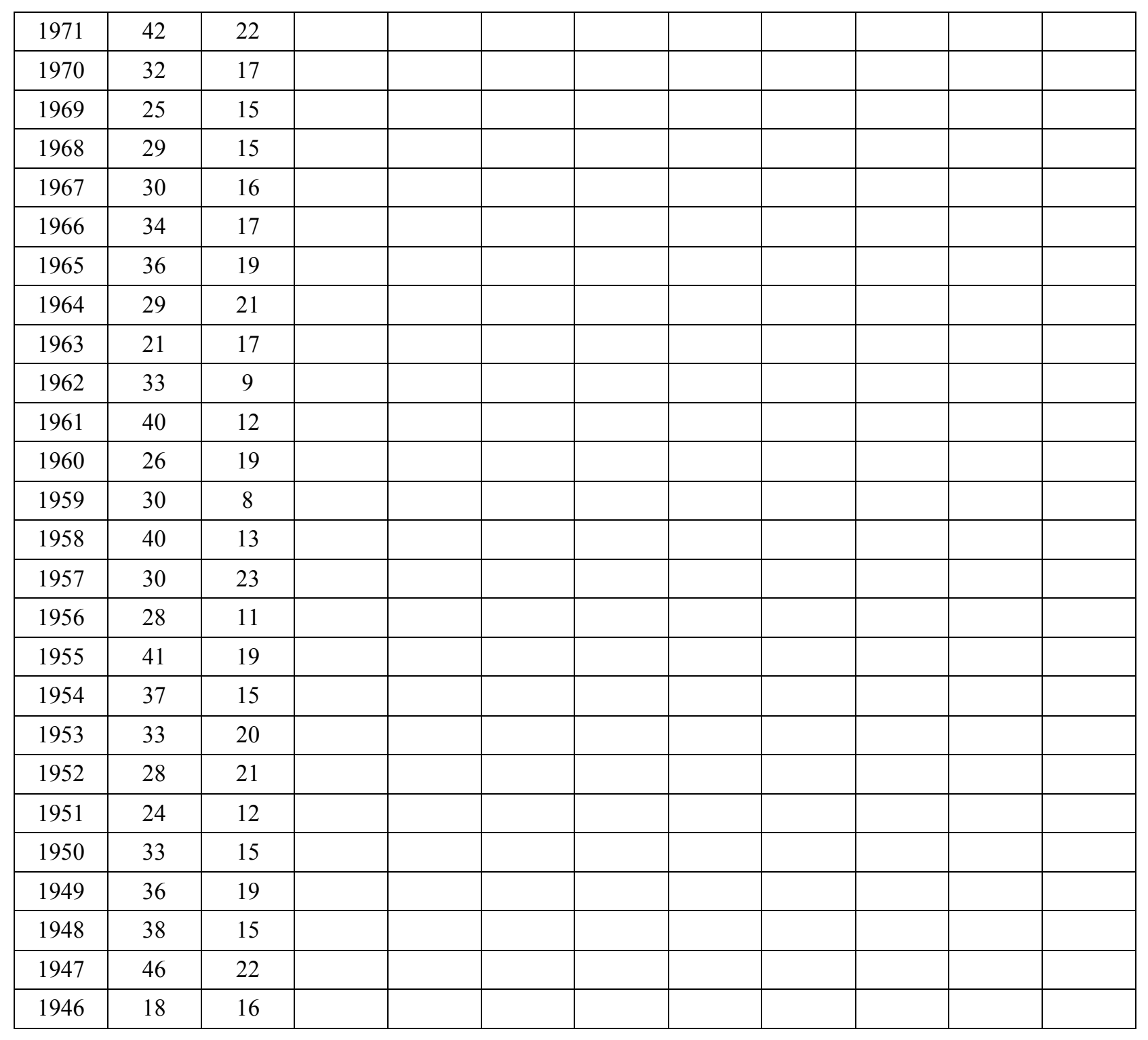


Table S3. Element/Ca ratios determined by laser ablation across 8 different transects obtained from the entire four coral C. rubrum specimens cross section. The $\mathrm{Mg} / \mathrm{Ca}$ ratio values were corrected based on the solution ICP-MS.

\section{Table S3 is provided as Excel-File.}


Table S4. Mean, maximum and minimum temperature from NOAA NODC WOA13 $\left(0.25^{\circ}\right.$ grid $)$ database and corresponding mean, maximum and minimum $\mathrm{Mg} / \mathrm{Ca}$ values obtained by laser ablation ICP-MS along the transects 2, 4, 6 and 8 of the samples RI, CO, MI and MS-43, respectively. The $\mathrm{Mg} / \mathrm{Ca}$ values were calculated by averaging the values from both sides of the transect (error $= \pm 1 \sigma \mathrm{SD})$

\begin{tabular}{lcccc}
\hline & $\begin{array}{c}\text { Mean T } \\
\left({ }^{\circ} \mathbf{C}\right)\end{array}$ & $\begin{array}{c}\text { Temperature error } \\
\left({ }^{\circ} \mathbf{C}\right)\end{array}$ & $\begin{array}{c}\text { Mg/Ca } \\
(\mathbf{m m o l} / \mathbf{m o l})\end{array}$ & $\begin{array}{c}\text { Mg/Ca error } \\
(\mathbf{m m o l} / \mathbf{m o l})\end{array}$ \\
\hline Mean RI & 15.97 & 2.57 & 118.63 & 3.72 \\
Mean MI & 15.84 & 3.05 & 126.99 & 6.96 \\
Mean CO & 16.78 & 3.32 & 122.16 & 3.55 \\
Mean MS-43 & 13.81 & 0.07 & 114.87 & 2.88 \\
Max T $\left({ }^{\circ} \mathbf{C}\right)$ RI & 21.26 & 0.22 & 131.53 & 7.50 \\
Max T $\left({ }^{\circ} \mathbf{C}\right)$ MI & 20.96 & 0.34 & 149.23 & 8.51 \\
Max T $\left({ }^{\circ} \mathbf{C}\right)$ CO & 22.73 & 0.46 & 132.79 & 7.57 \\
Max T $\left({ }^{\circ} \mathbf{C}\right)$ MS-43 & 13.92 & 0.03 & 120.69 & 6.88 \\
Min T $\left({ }^{\circ} \mathbf{C}\right)$ RI & 13.07 & 0.04 & 109.17 & 6.22 \\
Min T $\left({ }^{\circ} \mathbf{C}\right)$ MI & 12.55 & 0.15 & 114.68 & 6.54 \\
Min T $\left({ }^{\circ} \mathbf{C}\right)$ CO & 13.00 & 0.09 & 112.26 & 6.40 \\
Min T $\left({ }^{\circ} \mathbf{C}\right)$ MS-43 & 13.68 & 0.02 & 101.96 & 5.81 \\
\hline
\end{tabular}


Table S5. Winter and summer temperatures from T-MedNet and their corresponding $\mathrm{Mg} / \mathrm{Ca}$ values obtained by laser ablation ICP-MS along the transect 4 of the sample CO (Side 2)

\begin{tabular}{ccccc}
\hline Year & $\begin{array}{c}\text { Winter/summer T } \\
\left({ }^{\circ} \mathbf{C}\right)\end{array}$ & $\begin{array}{c}\text { Temperature } \\
\text { error }\left({ }^{\circ} \mathbf{C}\right)\end{array}$ & $\begin{array}{c}\text { Winter/summer Mg/Ca } \\
(\mathbf{m m o l} / \mathbf{m o l})\end{array}$ & $\begin{array}{c}\text { Mg/Ca error } \\
(\mathbf{m m o l} / \mathbf{m o l})\end{array}$ \\
\hline Winter 2007/2008 & 13.52 & 0.14 & 115.48 & 2.05 \\
Summer 2007 & 22.02 & 0.64 & 124.55 & 0.46 \\
Winter 2006/2007 & 14.41 & 0.21 & 116.79 & 1.00 \\
Summer 2006 & 21.39 & 0.52 & 124.95 & 0.50 \\
Winter 2005/2006 & 12.91 & 0.10 & 115.29 & 0.33 \\
Summer 2005 & 21.26 & 1.79 & 121.67 & 0.26 \\
Winter 2004/2005 & n.d. & n.d. & 115.62 & 0.21 \\
Summer 2004 & 22.68 & 1.72 & 127.36 & 0.74 \\
\hline
\end{tabular}

